\title{
Politics and Profit: Limited Democracy and the Press in Post-Apartheid South Africa
}

\author{
Submitted to the Faculty of Graduate Studies and Research \\ in partial fulfillment of the requirements for \\ the degree of Master of Arts

\section{Department of Communication} \\ School of Journalism and Communication
}

\author{
Carleton University \\ Ottawa, Ontario \\ September 2009
}




\section{Library and Archives Canada}

Published Heritage Branch

395 Wellington Street Ottawa ON K1A ON4 Canada
Bibliotheque et

Archives Canada

Direction du

Patrimoine de l'édition

395, rue Wellington

Ottawa ON K1A ON4

Canada
Your file Votre référence
ISBN: $978-0-494-64446-1$
Our file Notre refference
ISBN: $978-0-494-64446-1$
NOTICE:

The author has granted a nonexclusive license allowing Library and Archives Canada to reproduce, publish, archive, preserve, conserve, communicate to the public by telecommunication or on the Internet, loan, distribute and sell theses worldwide, for commercial or noncommercial purposes, in microform, paper, electronic and/or any other formats.

The author retains copyright ownership and moral rights in this thesis. Neither the thesis nor substantial extracts from it may be printed or otherwise reproduced without the author's permission.
AVIS:

L'auteur a accordé une licence non exclusive permettant à la Bibliothèque et Archives Canada de reproduire, publier, archiver, sauvegarder, conserver, transmettre au public par télécommunication ou par l'Internet, prêter, distribuer et vendre des thèses partout dans le monde, à des fins commerciales ou autres, sur support microforme, papier, électronique et/ou autres formats.

L'auteur conserve la propriété du droit d'auteur et des droits moraux qui protège cette thèse. Ni la thèse ni des extraits substantiels de celle-ci ne doivent être imprimés ou autrement reproduits sans son autorisation.
In compliance with the Canadian Privacy Act some supporting forms may have been removed from this thesis.

While these forms may be included in the document page count, their removal does not represent any loss of content from the thesis.
Conformément à la loi canadienne sur la protection de la vie privée, quelques formulaires secondaires ont été enlevés de cette thèse.

Bien que ces formulaires aient inclus dans la pagination, il n'y aura aucun contenu manquant. 


\begin{abstract}
Politics and Profit: Limited Democracy and the Press in Post-Apartheid South Africa argues that contemporary debates about press reform are rooted in the country's limited post-1994 democratic dispensation. Beginning with the Christian mission-based press circa 1850 , the thesis traces the industry's emergence and evolution along axes of profit and politics. It recounts this historical past to help illuminate some of the constraints imposed on the pursuit of institutional reform in the post-apartheid era, particularly those affecting the press and the media more broadly. In particular, the thesis shows how the exclusion of black South Africans from political and economic power has historically been reflected in their exclusion from the South African public sphere. I then show how this continues to be the case, although with some significant changes, because of constraints imposed on the post-apartheid government's ability to pursue fundamental institutional reform. It concludes with several suggestions as to how South African newsrooms might yet use their operational control to challenge the parameters typically imposed by the institutions of the commercial free press.
\end{abstract}




\section{Table of Contents}

List of tables iv

1. Media and Democracy in South Africa 1

2. Politics and Profit: The South African Press 1850-1990 22

3. The Resistance and Alternative Press 50

4. Limited Democracy, Press Reform and the Post-Apartheid State $1990-2005$

5. News and Journalistic Work in the New South Africa:

$\begin{array}{ll}\text { Contemporary Issues } & 102\end{array}$

6. Conclusion 123

$\begin{array}{ll}\text { Appendices } & 128\end{array}$

$\begin{array}{ll}\text { Bibliography } & 131\end{array}$ 


\section{List of Tables}

Table 2.1 Argus Printing and Publishing Major Shareholders $1910 \quad$ p. 37

Table 2.2 Argus Printing and Publishing Major Shareholders 1926 p. 37

Table 4.1 Market Share of Circulation by Group 1994/95 p. 102

Table 4.2 Market Share of Circulation by Group 2008 p. 103 


\section{Chapter 1 Media and Democracy in South Africa}

South Africa is at a crossroads. Fundamental political, economic and cultural institutions that were painstakingly debated, unmade, and remade during the 1990s are being contested anew. This is especially true of the press. Indeed, some argue that "what is really at stake in debates about the South African media [is] the ... workings of post1994 democracy" (Jacobs 2003: 43). This thesis assesses the renewed debates over the future of media in South Africa, particularly in terms of the ownership, organization, control and operations of the press. It also highlights the critical role that the press plays in structuring these debates. In other words, this thesis takes the political economy of the press as a critical index of the character and state of democracy in post-apartheid South Africa.

The contested future of the country, and the central role of the newspaper industry in that future, have been thrown into sharp relief by the ongoing allegations stemming from a controversial arms deal that has threatened to tear apart the post-apartheid political establishment. The origins of the scandal lie in the Government's contentious 1998 plan to re-equip the South African military forces. However, since 2000, the deal has been ensnared in a tangled web of cover-ups that have brought into question the integrity of key democratic institutions, including Parliament and its oversight of Cabinet, and the Constitutional Court. Amidst a chorus calling for a formal inquiry, the leadership of the governing African National Congress (ANC) have repeatedly stymied investigations. While it is beyond this thesis to discuss the intricacies of the arms deal debacle, the issue does highlight the pivotal place of the press in debates over the future of South Africa. 
While the secrecy and partial truths surrounding the arms deal are the stuff of political scandal the world over, the media's role in reporting on the scandal comes at a time when the media itself is under fire for its apparent lack of transformation. The context in which the country's papers cover the arms deal underscores the precarious state of the press in post-apartheid South Africa. Charges against Jacob Zuma were originally laid in 2006 after the conviction of his financial advisor. These charges were appealed and repeatedly delayed before being reinstated in December 2007, on the heels of the ANC National Conference where Zuma had defeated then-President Thabo Mbeki for the party leadership. At this Conference party membership also passed a resolution entitled "Communication and the Battle of Ideas" in which the party claims to be faced with a major ideological offensive, largely driven by the opposition and fractions in the mainstream media, whose key objective is the promotion of market fundamentalism, control of the media and the images it creates of a new democratic dispensation in order to retain old apartheid economic and social relations. (ANC 2007: 44)

The above quotation underscores the centrality of the media in the current South African political climate. The resolution states that the existing self-regulatory mechanisms of the print media in particular are inadequate and calls for the establishment of a statutory Media Appeals Tribunal, accountable to Parliament, to "complement" the work of the Press Ombudsman and Press Council. This is tantamount to calling for the external regulation of the press, a sacrilegious notion in the eyes of liberal theories of the "free press" and notions of the $4^{\text {th }}$ estate. As such, it seems to be a blemish on the democratic bona fides of South Africa. 
However, are the issues so simple, or do we need a more complex discussion of a much more complex situation? Generally speaking, criticism of the South African press stems not just from the ruling party, but also from the private sector and civil society. It is critiqued for its representation(s) of the country, its leadership, its people, and even of the continent. One might observe that, in offending equally, the media must be doing its job.

Three crucial background realities shape the context within which these issues in all their complexity - must be treated: first, the leaders mentioned were and/or are part of the post-apartheid governing elite charged with the formidable tasks of "transition" and likely to dominate the political scene for the immediate future. Second, such calls for action against the media take place against a history of censorship and intimidation on the part of the apartheid state, a history which is part of the living memory of many media workers still working in the country. Third, the media industry itself has and continues to undergo transition as it comments on the nature of that transition and the larger one of which it is a part.

Consequently, following the "honeymoon period" of the immediate post-1994 years, the frustrations that have arisen between the government and the establishment press are arguably a function of each trying to find its feet in new circumstances that continue to be fundamentally tied to historical constraints and baggage (Wasserman and de Beer 2006). The resulting antagonism has turned into somewhat of a chicken and egg problem: journalists find access increasingly closed, government more tightly controls access because of misrepresentation and even journalistic malpractice; stories are run without official sources and both parties end up in court arguing over their respective 
rights. The Media Appeals Tribunal looms in the background as a potentially more concrete manifestation of this antagonism. The media professionals, trainers, analysts and activists whom I interviewed were fairly adamant that such a tribunal would not stand up to constitutional scrutiny - but this is in a context in which the very court charged with upholding that constitution must contend with threats to its own integrity.

The fallout to the arms deal and growing government-press antagonism highlight issues of transparent government, a free press, and constitutional safeguards, all of which form the matrix of common and contemporary understandings of democracy and people's right to participate in their governance and society. This is a right that must be defended against opaque authority and arbitrary rule. One means of providing for these rights is through a focus on certain "systems dimensions" of democracy. According to early- and mid- $20^{\text {th }}$ century theorists of democracy, especially Max Weber, Joseph Schumpeter and Walter Lippmann, democracy depends on institutions designed to check arbitrary, haphazard rule and excessive political patronage. It also depends on publicly known procedures to deal with routine difficulties and relatively clear-cut rules and laws that allow people to measure and/or investigate the legitimacy of decisions and decisionmaking processes. The complexity of modern industrial society also means that there are inherent limits on public participation in political, economic and public affairs (Held 1996: 161) - that is, modern democracy is, by necessity and nature, limited democracy. This technocratic approach to democracy is meant to ensure that the spheres of economic and public life are regulated primarily by the rule of law, and that relationships between the governors and the governed are regulated via the available means of representation and accountability. 
This theory of limited democracy helps to explain the prominence of centralized states and complex bureaucracies in contemporary democracies, as well as the focus on institutional change in new democracies. These objectives are clearly a necessary improvement on the arbitrary, unjust and tangled web of legislation that comprised apartheid. As such, getting the institutional architecture "in order" has been a necessary part of the post-apartheid reconstruction of South African democracy. However, this also raises important questions about the character and constraints of the particular model of (limited) democracy that has been created and which is being progressively locked into place over time. How have historically given property relations, particularly those that have emerged around the dominant media institutions in South Africa, constrained the path of institutional change? Has the focus on institutional change come at the expense of substantive changes in terms of equality and a more robust "culture of democracy"? Has it overshadowed more popular and spontaneous means and manifestations of participation and representation, and in so doing, institutionalized their exclusion?

Debates about press reform crystallize these questions and call attention to the gap between pressures and policies designed to transform the structure of the industry, on the one hand, and continuing trends in newspaper coverage and journalistic work, on the other, that contradict claims that substantive changes have taken place. In this vein, criticism levelled at the material base and motives of the press bear consideration in relation to historical constraints and baggage, and indeed, in relation to democracy itself. In writing on contemporary media ownership and control in Africa, Nyamnjoh cautions communication scholars against getting preoccupied with challenges of globalization and neoliberalism while neglecting more traditional but still potent impediments to freedom 
of expression: "What neoliberalism wants of them, as governments, are national and regional policies in tune with the needs of capital ... Mindful of this, it should surprise few that the mediascape in Africa at the age of globalization is one of continuity rather than change" (2004: 123-4). He argues that post-liberalization/democratization media legislation demonstrates a "craving to control" that is, at least in part, a function of the pressure to adopt economic policies that may not enjoy domestic popular support. Journalists are consequently seen as troublemakers, resulting in a crisis of credibility for the press (Nyamnjoh 2004: 125).

This is not to suggest that the South African press speaks out uniformly, or even predominantly against the neoliberal macroeconomic policies that have been adopted by the Mbeki administration since the late 1990s. The opposite is more the case. The paradox plays out in the give and take between the media's imperatives as both a democratic institution and capitalist enterprise. The earliest newspapers served a more directly business function in providing market intelligence to their readers (Garnham 1990). As a business itself, and a highly profitable one at that, media houses stand to benefit from the economic boost provided by (foreign) investment. The particular nature of their business means they play a significant role in shaping perceptions about the favourability or hostility of the country's investment environment. This does not, however, translate into unabashed support for government policy or a rose-tinted view of South Africa's dire socioeconomic realities; quite the contrary, as indicated by at least some of the criticism levelled against the press. The press is not a government mouthpiece, and at any rate, failure to provide even a surface portrayal of life for the majority of the population would further harm its credibility. 


\section{Methodology}

This research is based on a review of primary and secondary material and field work undertaken in July and August 2008. Government documents comprise the bulk of primary material referenced and include the South African Constitution of 1996, the Interim Constitution of 1993, and pre- and post-1994 bills and Acts of Parliament. Other primary material includes submissions to and reports of government-appointed and independent commissions, inquiries and task groups, political party documents, and information from corporate and other websites, such as those of media groups and the Press Council. Secondary material consists of the scholarly literature on South African socio-political and economic history, the political economy of the media, and democratic theory and democratization.

During my field work I was based primarily in Johannesburg, the country's economic and media hub; two of three commercial print media conglomerates - Avusa and Media24 - are based here, as is the South African Broadcasting Corporation. Pretoria, the executive and de facto national capital, is about an hour's commute away and hosts the Department of Communication and the Government Communication and Information Service. While the online public portal of the latter offers access to most government-related documents, part of my field work consisted of tracking down submissions made to the Task Group on Government Communications. Though I did manage to secure some of these, in the end, the balance of my field research consisted of personal interviews with a range of figures involved in the press industry, including journalists, editors, regulators, policy-makers, government communicators, and 
academics. These interviews offered invaluable insights into the country's present media environment and helped to contextualize my understanding of the industry's past and more recent history. Their strength lay in the range of expertise and experience represented by interviewees: black and white journalists who had worked under apartheid, through the transition period, and who now participate as editors, columnists, journalism professors, and, in the case of one, as Press Ombudsman; newer black journalists, trained in formal journalism schools and/or in the newsrooms; directors of non-profit media-oriented organizations involved in monitoring media coverage and in making submissions on legislation and policy impacting the media environment; a director of a for-profit media firm geared towards risk analysis and positional strategizing for corporations, financial institutions and government; and government communicators, including a departmental spokesman and those working specifically for the Government Communication and Information Services.

Of course, this range of perspectives is not exhaustive or entirely representative of the industry. In terms of present-day media groups, journalist interviewees hailed from the South African-based Avusa and Media24 rather than from the foreign-owned Independent Newspapers. This short-coming is due partly to the manner in which potential interviewees were approached - personally versus "cold calling" - and partly to location: Independent Newspapers is based in Cape Town. I was also unable to conduct personal interviews with media owners, ostensibly because of scheduling conflicts and general timing issues. Thus the ownership perspective presented here is largely based on second-hand sources, such as the reports of the Truth Commission media hearings and the Human Rights Commission hearings into racism in the media. Otherwise, my 
material on how media owners and institutions have played a role in restructuring the South African media and ongoing debates is largely descriptive and sourced from newspaper stories, interviews, academic sources, and media group websites.

The reader will find that many players exist on the stage of South African press politics. They often enter and exit at irregular intervals. To assist the reader in keeping a sense of it all, and to avoid the need to constantly refer to a list of acronyms, I primarily use the full name of the organization concerned, with the exception of the African National Congress (ANC). In sections where repeated reference is made to an organization, I occasionally use an abbreviated form but ensure that it is clear that I am dealing with the same organization. For example, the South African National Editors' Forum is shortened to the National Editors' Forum within the same section or paragraph.

For names of Afrikaner companies I use the English translations and footnote the original Afrikaans name, with the exception of Naspers and Perskor, short forms of Nasionale Pers and Pers Korporasie respectively. In their case I have footnoted the English translation ("pers" is "press"). Conversely, Afrikaans newspaper names are retained, as translation would confuse them with English-language papers of the same name. For example, Die Burger translates into The Citizen, which is also the name of an English-language tabloid with a history quite particular to its language of publication.

Apartheid-era press houses went through various transmutations, with interlinking and interchanging ownership. The four main press groups that have persisted for most of the twentieth century, and in some cases until the present day, are the Argus Printing and Publishing Company, South African Associated Newspapers, Nasionale Pers and Pers Korporasie. For coherency and brevity, I refer to these four major press groups as: 
Argus, SAAN (South African Associated Newspapers), Naspers and Perskor. All other company names will be given in full.

The use here of the term "black" follows the democratic era definition as those disadvantaged and discriminated against under apartheid. "Black" should be understood to include the apartheid-era categories of "Indian" and "Coloured" unless otherwise stated. To exclude these latter two groups from discussions that did not directly affect them, such as that of the Bantustans, I refer to black Africans. Lastly, for consistency and geographical clarity, I refer to black and white South Africans throughout this work, even though the Union of South Africa technically did not exist until 1910.

\section{Theoretical Framework}

A political economy of the media seeks to trace and explain the contradictions between structural changes and continuing trends in newspaper coverage, by looking at how communication and information as resources function and are managed within particular social formations. The historical dimension of this approach focuses on the process of social change, for example, from feudalism to capitalism, the dynamics and trajectory of the latter, the wider socio-political implications of such changes and the challenges they pose to accepted notions (Meehan and Mosco 1993). The social totality dimension seeks to understand the relationship between commodities, institutions, social relations and hegemony (Meehan and Mosco 1993). Hegemony is here understood as the development of a consensus culture in which those in the working class identify their interests with those of the bourgeoisie and so work to maintain rather than overthrow the status quo (Holsti 1985). The historical and social totality dimensions are in turn embedded in a moral philosophical outlook. As Golding and Murdock observe, critical political 
economy of communication "goes beyond technical issues of efficiency ... to engage with basic moral questions of justice, equity and the public good" (Golding and Murdock 1991: 18-19).

A political economy approach seems particularly appropriate to the contested development of South Africa and its press industry post-apartheid. However, it also raises the thorny question of what exactly is meant by notions of transformation and change: "from what to what?" is the key question, as Steenveld (1998) puts it. Broadly, by transformation I mean the move from unfair institutionalized discrimination to a nonracial society; from a non-democratic dispensation to a democratic one; and from mass under development to development (Berger 2000). More broadly, transformation refers to a move from systematic processes of racial exclusion to ones designed to further inclusion, at various levels of the country's political economy. As far as the mass print media is concerned, two questions arise: what can be said of the industry's transformation in relation to the above goals? Moreover, what is the role of the press in reflecting and bringing about such notions of transformation?

To answer these questions, one must take into account the "mixed mission" inherited by the mass media, as both a democratic institution and a capitalist enterprise (Peters 1993: 559). In the early debates on transforming South Africa's media, key constitutional negotiator and Minister of Communication Roelf Meyer argued that "it is unreasonable to expect the media to be objective... The important thing is that the marketplace should be open to the purveyors of all ideas and that the public should have the right to browse and buy as they please" (1992: 361). Ruth Teer-Tomaselli, Cultural and Media Studies lecturer, countered: "It's no good talking about this in the same ethos 
as freedom of speech. Freedom of speech means that you buy what you want. When you go to the CNA [Central News Agency] you buy the magazines you want, but that presupposes that you have money in your pocket" (1992: 199). This exchange highlights the way in which a political economy of the press must take into account the broader (re) construction of society. A political economy of the South African press thus situates media organizations within the overall framework of a society moving from apartheid to one that aims to be far more democratic.

The interplay between processes of inclusion and exclusion is a key dynamic that links the construction of a society to the character of its communications media. In this regard, Jürgen Habermas (1974) highlights the relationship between capitalism and liberalism that brought about both the emergence and eventual decline of the bourgeois public sphere. The public sphere is characterized by its having an economic base free from state control and with an autonomous base of power anchored in privately-held capital. Capital is here understood as an abstract monetary-based exchange relation; capitalism subordinates social relations to the universalization of this exchange relation (Garnham 1990). Habermas situates the public sphere as a category of bourgeois society and thus implies but does not adequately theorize the exclusion of significant populations from a particular class of society and thus from the public sphere. In South Africa, these exclusions, by race, territorial boundaries and circumscribed rights in relation to mobility and labour, were mirrored within the country's media economy, where black labour and black media consumption were only partially absorbed into overall capitalist exchange relations. 
Apartheid was a system that functioned simultaneously through inclusion and exclusion, both political and economic. Prior to 1948 , black political participation was limited to consultative councils that were overseen by white magistrates and whose resolutions were not binding on Parliament. When the National Party came to power in 1948 it built a legislative system designed to extend this marginalization. The first step was to classify all South Africans according to race (the Population Registration Act 1951), and next, to require separate urban living areas according to these categories (the Group Areas Acts 1951). The black African population was hived off and relegated to one of ten "ethnic" homelands (the Bantu Authorities Act 1951), which together represented 13 percent of the country's land. These Bantustans, built on the existing Reserve system established by the Natives Land Act (1913), were ultimately a means of divesting the vast majority of South Africans of their land and their citizenship. Pitched as a reinstatement of traditional leadership, the homelands did have considerable administrative power. However, aside from casinos, strip clubs, and some mining, the Bantustans were dependent on the direct transfer of financial payments from the central government. The system of homeland administration by "national communities" was also a substitute for parliamentary representation, and thus a stark form of excluding black citizens from the political public sphere.

Marginalization was not only political but, crucially, economic. The participation of black South Africans, and black Africans in particular, in the economy was limited to the exploitation of their labour at low compensation. The inclusion of their labour was circumscribed by a colour bar that reserved more skills-intensive, as opposed to labourintensive, work for white South Africans. In this way, apartheid was a means of securing 
the conditions for the production and reproduction of cheap labour in the era of industrial manufacturing; it was also a means of protecting white job security, and high white wages against competition from black workers (Wolpe 1980). Replacing the Reserve system with the Bantustans was integral to this process.

In the early period of South African capitalism (roughly 1870 to the 1930s), the agricultural economy and kinship distribution of the Reserves helped reproduce cheap labour by providing for the subsistence of the migrant worker, who returned home between periods of work, largely in the mining industry (Wolpe 1980). In other words, workers were underpaid and the Reserves made to pick up the slack, or the social costs of exploitation. However, as the Reserves deteriorated and workers were increasingly drawn to the urban areas, impoverishment deepened while industrial and political unrest in both urban and rural areas intensified (Wolpe 1980). The policy of maintaining cheap African labour power by force underpinned the platform which brought the National Party to power in 1948. The aforementioned legislation, along with updated Native Urban Areas Act (1923) and Pass Laws (1925), reinforced the status of black African citizens as sources of cheap industrial labour and further marginalized them in the political sphere through the façade of self-administered, though not self-governing, "homelands". In short, the traditional exclusions of liberal democracy and the bourgeois public sphere appeared in an extremely stark form in South Africa.

The severely stunted position of black citizens under apartheid was replicated in the country's media economy. In most capitalist democracies the industrialization of the press was accompanied by the de-politicization of the latter (Habermas 1974; McChesney 2000). In South Africa, however, this was not entirely the case, given the partisan ties of 
the press to ethno-linquistic groups (Afrikaaner and Anglophone) and, especially with respect to the Afrikaaner press, to political parties steeped in the project of building the nation-state and forging an ethno-linguistic sense of national identity. The relationship between the differing economic bases of the press and the politics of South Africa can be seen in the distinctive, yet thoroughly intertwined development of the English, Afrikaans and black press.

For the most part, the English-language press developed as an adjunct of largescale English mining conglomerates. More than the Afrikaaner press, the English press was primarily, though not wholly, driven by profit. Its politics were mainly geared toward protecting and expanding the business interest of English capital rather than more vexing questions of political, ethnic and linguistic identity, or the need to build a strong nation-state as an emblem of sovereign political identity. This lent to the English press a liberal ethos which, in turn, provided a broader material base for black journalism relative to the Afrikaaner press. Of course, this was only a matter of degree; black participation in the economy took place under very narrowly defined conditions, and black readers were hardly seen as a valuable market for advertisers - the real economic base of the press.

The Afrikaans press, in contrast, was less inclined to approach a black press as an "untapped" demographic because of its defensive posturing, both in relation to English capital and the potential for black majority rule. The Afrikaans press did not arise from a stable base of large-scale capital but was created to help foster such financial power and harness it towards achieving Afrikaner dominance within the political public sphere - a goal that was realized with the National Party electoral victory in 1948. As a result of its 
relatively weak financial position and more explicit political project, the Afrikaans press had less institutional autonomy from the apartheid state than the English press.

Just as the English press might be said to have followed the logic of capital more strictly, so too can it be said that the press in general followed another tendency born of the same logic: namely the tendency to become concentrated. The "free" market as "a fair, just and rational allocation of goods and services" is premised on the existence of competition which is by no means guaranteed or even logical to sustain (McChesney 2000: 138). The logic of the market is such that "[a]ll investors and firms rationally desire to be in as monopolistic a position as possible" (McChesney 2000: 138). As will be discussed in the next chapter, it was less in the interests of English mining magnates to continue to compete with each other than to centralize production and thus to control the circulation of gold and diamonds in the market. Similarly, by the 1930s most of the existing English language and independent African papers had been subsumed under one press house, the Argus Printing and Publishing Company.

In addition to a tendency towards concentration as opposed to competition, the mythology of the marketplace as "fair" and "just" is further compromised by the historically given and unequal set of property relations in which it is set. The distribution of wealth and resources were skewed to begin with: the free merchants who traded in the earliest capital markets proceeded on a material base rooted in slavery and serfdom. In the South African case, then, the concentration of capital and the exclusion of certain groups from society compounded one another, and this is no less true in the case of media markets. In other words, the limits of the "mediated" bourgeoise public sphere are especially apparent in South Africa on account of the legacy of apartheid. As I 
understand things, race is not an external and distorting force in an otherwise rational economic system, but intricately implicated in the very way that capitalism has and continues to function in South Africa. The capitalist social formation has always depended on an underclass and in South Africa race was its defining characteristic. Nowhere was this better understood than amongst those who bore the brunt of the system. As Black Consciousness writer Njabulo Ndebele wrote in 1972

Apartheid is no longer a pseudo-ideology; it has become an economic principle. This is an important development for the black person. It means that the black man must be careful of concentrating on the racial struggle, to the detriment of the economic struggle, because the latter may have become more important than the former. (Section III b)

This understanding of apartheid's material underpinnings gave a prominent place to an explicit policy of nationalization in the liberation movement and among black political parties. The meaning and status of the issue varied across parties, notably the ANC and the South African Communist Party. Nelson Mandela, for instance, accepted the notion that resources need to be nationalized as part and parcel of a militant African nationalism pitched against foreign rule and imperialism. However, he and many others in the ANC leadership were wary of the linkage between such a move and communism, with the latter seen as an ideology just as foreign to Africa as were colonial notions of "culture" and "civilization" (Mandela 1995: 100). The key issue seemed to boil down to whether a revolutionary nationalization of resources and key sectors of the economy would win the struggle against apartheid or if more pragmatic policies were needed. There was, and is, no easy answer to this question, and its vexatious nature still hangs over the processes of economic reform in general and of press reform more specifically, as this thesis shows. 
Unlike the broadcast and telecommunications sectors, the ANC-led government largely left the press alone, pledging instead to expand opportunities via assistance to community and non-commercial media (Horwitz 2001). This did not mean that the press was not expected to change, as subsequent dissatisfaction with the press, mentioned earlier and discussed further in chapter five, demonstrates. But it did mean that transformation was largely left to the industry. Here change did occur in the racial composition of ownership, boardrooms and newsrooms. In some cases, editors expanded participation in editorial and news conferences in order to compensate for the lack of black journalists with the skills and training to hold senior positions (South African Human Rights Commission 2000). Several editorial appointees hailed from the dying alternative press and brought a fresh set of perspectives into the mainstream (Kruger 2004). However, the logic of the news business did not change. If anything, it was sharpened with the entrance of large-scale foreign capital and the introduction of modern management practices into the industry.

Advertising is a fundamental part of the business of news and it has had particular effects in the case of South Africa's media economy. The connection between advertising and the press originated in $19^{\text {th }}$ century processes of industrialization that made possible the mass production of both media and consumer goods. Reduced copy prices increased the circulation and individualized consumption of newspapers, making them an ideal advertising medium for the competitive selling of branded goods (Murdock and Golding 1974). By selling advertising space, newspapers were able to further drive down their copy costs such that today, circulation accounts for one-third of revenue while advertising accounts for two-thirds (Fourie 2004). Yet advertisers are not interested in all 
audiences but in those with disposal income, the more the better. For this reason Dallas Smythe (1977) argues that the actual business of mass media is to sell audiences to advertisers. The resulting newspaper market is more reflective of advertiser preference than reader choice, and those papers that rely on the latter are at a disadvantage (Herman and Chomsky 1989).

With the rise of advertising support, chain newspapers, and one-newspaper towns, partisan journalism became less viable as it might antagonize valuable segments of readers and jeopardize a newspaper's legitimacy (McChesney 2000). The commercial limits of partisanship resulted in the professionalization of journalism in the $19^{\text {th }}$ century around ideas of impartiality and objectivity, while the commercial push for "new" news contributed to a superficial portrayal of reality "where things happen but nothing really changes" (Murdock and Golding 1973: 229). The overall result of these processes has been shallow, depoliticized coverage that generally upholds the status quo. Conflating the needs and actions of people as citizens with those of consumers thus gives rise to the contradiction of a free press that is undemocratic in its coverage and reach. This is, in essence, the charge levelled at the South African press industry, both in the past and still today, albeit in attenuated form, where media resources are concentrated and geared towards profit maximization and the most "valuable", or sought after audiences. In other words, the audience commodity ramifies the exclusions of the public sphere, although not without some quite significant exceptions. 


\section{Chapter Overview}

This thesis applies these ideas to a study of the South African press over the course of the next five chapters. In the following chapter I map the emergence of an industrialized urban mass press in South Africa. It will begin with the missionary press and the emergence of the mining industry in the latter half of the nineteenth century. The latter in particular was a key player in the South African economy at large and in the establishment of the English-language press in particular. The split between the industrialized press controlled by the mining industry and the press of the Afrikaner political groups is a key distinction that plays a pivotal role throughout the history of the South African press. The one follows well-known lines of the commercial press where political objectives are subordinated to commercial objectives, but without the former being abandoned altogether; the other was much more explicit politically. The chapter gives an overview of British-Afrikaner antagonism as it contributed to these developments, looking at the mobilization of capital amongst the latter group, and the Afrikaans-language press groups that arose as a result. The aim of this chapter is to sketch how the contradictory imperatives of profit and partisanship shaped the South African press industry as a subset of the country's broader political economy.

The third chapter goes on to consider the ambivalent history of the white-owned black press as well as the emergence in the 1980s of an alternative press. Chapter four proceeds to show how this mixed legacy, of profit and partisanship, interacted with the imperatives of transformation during the 1990s. It considers the transformation of the press industry within a larger politics of transition characterized by corporatism and continuing exclusions within the country's political economy. The purpose of this 
chapter is to demonstrate how media interests have been reorganized according to multiracial democratic capitalism but without the desired level of transformation. Chapter five goes on to discuss how dissatisfaction with the transformation of the press industry is a function of government-led reform to change the racial basis of capital while leaving its logic and dominance insulated from interference. Consequently, the focus of transformation has switched from the boardroom to the newsroom, where government attempts to influence content and staffing have brought into question its commitment to press freedom.

Chapter six offers an alternate view of how change might be achieved in the newsroom, via the agency of editors and journalists. It will suggest that changes in the country's political economy and newsrooms, however limited, offer an opportunity for real transformation in covering the new South Africa. 


\section{Chapter 2 Politics and Profit: The South African Press 1850 - 1960}

For much of the $20^{\text {th }}$ century, South Africa's press industry was dominated by four groups: the Argus Printing and Publishing Company, and South African Associated Newspapers, (both English-language), and Nasionale Pers, and Perskor (both Afrikaans).' The first two have historically been tied to English mining capital and the latter two to the Afrikaner nationalist political project. The roots of the industry as a whole are closely intertwined with two manifestations of British imperial endeavour within the country: Christian missionary work, and gold and diamond mining. It was under the aegis of the former that the first black African- and English-language newspapers began. The mining industry in turn contributed to the founding of the white English-language and Afrikaans press in direct and indirect ways. Directly, it provided the founding finance for the English press. Indirectly, it represented a virtual reserve of large-scale Englishdominated capital, against which dominant Afrikaner capitalists organized themselves. The goal of the latter was to mobilize Afrikaner interests and sentiments into an overarching nationalism capable of gaining the political and economic upper hand. The Afrikaans press thus arose as one mechanism of political mobilization. The English press, on the other hand, functioned primarily as a business enterprise, though this did not extinguish its political character. This chapter traces the emergence and interconnected development of these three press groupings - African, English and Afrikaans - as a subset of South Africa's broader political economy, and, consequently, as an industry fundamentally shaped by the conflicting imperatives of profit and politics. It will moreover show that, in the history of the South African press, partisanship as an explicit

'Hereinafter "Argus", "SAAN", "Naspers", and "Perskor" respectively 
political project has predominantly taken the form of nationalism and nation-building "nation" being defined inclusively and exclusively by different groups depending on their interests. The distinct yet interrelated histories of the African, English and Afrikaans press represent attempts to stake out and secure their respective interests in the country to harness cultural power in order to generate and justify their claim to political and economic power. This legacy was to have a profound impact on the press and nationbuilding in the new democratic era.

\section{African Journalism ${ }^{2}$}

In South Africa, as elsewhere, literacy and Western education went hand-in-hand with missionary activity and the "civilizing" mission propounded by British imperialists. Literature and education were a means of spreading the gospel, as evidenced by the pattern of translating the Bible into indigenous languages - in this case Xhosa. Thus missionary stations became centres of learning and it was under Christian auspices that the first African-language newspapers began. The missionary press was not primarily a profit-oriented enterprise, but first and foremost a part of the British imperial "civilizing" mission. As such, its contribution to the development of African journalism demonstrates how the material base of media can set certain limits on its use, but cannot predetermine the final outcomes of human action or, in this case, reactions to the media. This is the profoundly subversive contradiction inherent to the cultural commodity (Garnham 1990). Hence, while the first generation of African journalists were, to a significant extent, products of imperial inculcation, their use of the written word and English literacy

\footnotetext{
${ }^{2}$ Here I rely extensively on the work of Ndletyana (2008).
} 
ultimately allowed them to challenge imperialism - and to forge an African nationalism in response.

Between 1837 and 1881, five publications were launched, all in the Cape Colony: the quarterly Umshumayeli Wendaba (The Publisher of News); Ikwezi (The Morning Star) in 1844; Isitunywa Senyanga (The Monthly Messenger) in 1850; Indaba (The News) in 1861; and Isigidimi Sama-Xosa (The Xhosa Express, subsequently the Christian Express) in 1881. With the exception of the last, these papers did not last long, due to a small and inconsistent readership and the turbulence occasioned by the Frontier Wars. The Christian Express, along with Imvo Zabantsundu ("Native" or "African" Opinion"), the first non-missionary paper, launched in 1884, and Izwi Labantu (The Voice of the People), begun in 1897, were the only three African-focused papers that operated into the next century.

From 1854 onwards the colonial government began to subsidise missionary institutions to provide training in industrial occupations, interpretation, evangelizing and teaching. As evidenced in other British colonies, imperial strategy sought to create an indigenous middle class attached to and dependent on the colonial capitalist status quo. This population would also act as a buffer against and pacifier of the Xhosa population. This thinking would resurface in the 1970s amongst liberal members of the National Party as a means of protecting against the nationalisation of industry that at the time appeared to be part and parcel of the struggle for majority rule. Ndletyana pointedly notes that early converts were not merely "recipients of modernity" but "co-architects of South African modernity in their own right" (2008: 5). Yes, they were the subjects of the

\footnotetext{
${ }^{3}$ Ndletyana (2008) uses "Native," whereas Tomaselli and Tomaselli (1987) employ "African", to refer to the same paper.
} 
civilizing and Christianizing mission but they also sought to forge a new African identity. Such an endeavour inevitably gave rise to ambivalence.

The contested figure of John Tengo Jabavu is one such example. Jabavu, educated at a mission school, began teaching in 1876 at the age of 17 . During this time he also apprenticed at a local newspaper. In 1881 he became editor of Isigidimi (Xhosa Express), where he devoted space to parliamentary debates and to positive coverage of liberal politicians - such as then-Cape Argus owner-editor Saul Solomon, among others who were in favour of the franchise for black South Africans. When his contract expired three years later, he became a canvasser for the Cape politician R.W. Rose-Innes, who ended up winning a seat in the 1884 elections. Later that year Jabavu began and edited the first black secular newspaper Imvo Zabantsundu (Native Opinion) with the financial backing of Rose-Innes and James Weir. Imvo became associated with liberal Cape politics and advocacy of African issues - for a time. Editorials discussed parliamentary issues and the performance of representatives, and compared candidates; it opposed the pass laws. However, beginning in the late 1880s Jabavu became suspect among his readership, among other black leaders, and among his financiers variously, for his stance on certain key issues: the African franchise; the Anglo-Boer War; and the Native Land Act of 1913 which sought to severely restrict the right of Black South Africans to own land. The politicians whom Jabavu had supported were now in favour of restricting eligibility of black voters. On the issue of war, Jabavu perceived it as provocation on the part of the British and so came out in support of the Boers - whose politicians were not in favour of any African voting rights, especially since those Africans with the vote consistently elected English politicians. Jabavu supported the Native Lands Act (1913), 
contrary to most black leaders at the time. Innes and Weir withdrew their financial support and Imvo was also obliged to switch printers; it was banned under martial law in August 1901, but reappeared in October the following year. Jabavu's gradual alienation signalled a split in the black middle class of the time over how to address their subordination relative to the white population (Ndletyana 2008). It led to the establishment in 1897 of the rival paper Izwi Labantu (The Voice of the People).

Izwi supported the emerging African nationalist cause. It was founded by Reverend Rubusana and Alan Kirkland Soga, with the financial backing first of mining magnate Cecil Rhodes and then of his Progressive Party (Magubane 2004). Rhodes was a Cape parliamentarian at the time, and the two-party system that was emerging required securing the African vote as it then existed (Fredrickson 1995). Soga, himself the son of a reverend and educated in Scotland, was the paper's editor from 1898 to 1908 . Izwi grasped the significance of African labour's position vis à vis South African society, going so far as to predict that "the next war will be between labour and capital"; it included pieces from Britain's Labour Leader and the New York Socialist on worker conditions abroad (Limb 2000: 86-87). Izwi ceased publication in 1909. Rubusana and Soga were instrumental in initiatives that eventually led to the formation of the ANC in 1912 (named the African Native National Council at the time of its inception).

Founding members of the organisation were likewise integral to the proliferation of African journalism. In 1901 Solomon Plaatje, the ANC's first Secretary-General, established and edited the first Setswana-English weekly, Koranta ea Becoana (Newspaper of the Tswana), with the financial support of Dr. Silas Molema, a member of the royal Barolong family. Koranta condemned the working conditions in the mines, 
printing reports of mistreatment and letters of grievance. The paper ceased publication in 1908 and Plaatje eventually moved to Kimberley where he began the Tsala ea Becoana (Friend of the Bechuana), later renamed Tsala ea Batho (Friend of the People). Tsala reflected the personal opinions of its editor as well as core ANC ideas and the sentiments of the diverse social classes that supported it (Limb 2000). According to Limb, “"[m]iddle class' movements influenced Plaatje, but they in turn were responding to other influences, including the growing social presence of African workers" (2000: 91). Founding ANC President John Dube began Ilanga Lase Natal (the Natal Sun) in the Natal colony in 1903, operating out of the Zulu Christian Industrial School that he had established two years prior with the help of the American Zulu Mission.

Pixley Seme likewise studied abroad with the help of missionary assistance, obtaining a Bachelor of Arts degree from Columbia University before going on to study law at Oxford. Returning to South Africa in 1910 to set up a practice in Johannesburg, he was one of three lawyers who called for a convention of Africans to discuss the formation of what would become the African National Congress. Seme began the weekly AbantuBatho ("People" in Zulu and Xhosa, and Sotho and Tswana respectively) with the financial support of Swaziland's Queen regent. Printed in these four languages and English, the paper circulated nationally and was closely associated with the ANC, though it did not become its official organ until 1928. Its staff included Congress members versed in labour issues and involved in protests and in the International Socialist League. It generally reported on and condemned the state of workers in the country paying particular attention to the mistreatment of female workers. However, its relationship with labour did not manage to transcend race. While some editors urged class solidarity, the 
refusal of white craft unions to support black workers led Abantu-Batho to warn against collaboration with white labour (Limb 2000). For its part, the International Socialist League dismissed Abantu-Batho as being sponsored by the capitalist class (Limb 2000). In 1929 then-ANC President Josiah Gumede purchased a controlling share in the paper and for the next two years he and fellow editor Daniel Letanka took an anti-imperialist editorial line strongly in support of workers and African nationalism (Limb 2000). It ceased publication in 1931.

The audience for these papers was relatively small, comprised of literate black professionals from both rural missionary communities and emerging black urban neighbourhoods. As the latter grew so did it come to dominate the content of black publications (South African History Online 2000). However, though the audience was gradually increasing, by the 1940 s a combination of political and economic pressure saw this generation of the black press closed down, depoliticized, and/or subsumed by whiteowned commercial media (Switzer 2000).

In this regard, the monthly Drum magazine was somewhat of an anomaly. Originally known as The African Drum, it was apparently intended to depict black South Africans as noble savages and contained mainly tribal preaching and folk tales; its circulation was 20000 (South African History Online 2000). In 1951 Jim Bailey, exRAF pilot and son of mining magnate Sir Abe Bailey, took over the magazine, shortened its name to Drum, and changed its focus to black urban life; he hired his friend Anthony Sampson as editor. They established a black editorial board to ensure relevant content. Drum offices were not segregated and it was one of the few places at the time where aspiring black writers and photographers could gain training and experience. In March 
1952 Drum published its first investigative piece, exposing working conditions in the farming community of Bethal; sports editor Henry Nxumalo posed as a labourer in order to get material for his article. The edition sold out and was followed by other exposés, though Bailey did not permit reports or photographs of the Sharpeville massacre or of migrant labour conditions on the mines (South African History Online 2000). In August 1952 Drum set a new circulation record of 65000 with an edition that included an eightpage photographic essay of the Defiance Campaign. ${ }^{4}$ By the end of the decade 240000 copies were being distributed monthly, across the country, throughout the southern African region and in several countries in west and east Africa. Drum content ranged from journalistic to creative, counting arts and literary critics, short story writers, and biographers among its ranks. Their works comprised what later became known as the Sophiatown Renaissance; their heyday ended with the Sharpeville Massacre of 1960 and the subsequent government crackdown that led many of these writers to flee the country.

Despite its temporary success, Drum represented the tail-end of the first generation of African journalism. The missionary subsidization and subsequent mining and political party financing of the African press resulted in its constricted development, both in terms of content and reach, literacy rates also being a factor. Nonetheless, this press enabled a platform, however limited, for voices that challenged segregation and white minority rule.

The next major influence on early press development in South Africa after the missionary stage was that of the mining industry: the extraction and exploitation of precious natural resources.

\footnotetext{
${ }^{4}$ The Defiance Campaign against Unjust Laws was launched in June 1952 by the ANC and the South African Indian Congress as a national action calling for non-cooperation with discriminatory laws.
} 


\section{Diamonds, Gold and the "Industrialization of the Press"}

South Africa's mining industry is a behemoth within that country's historical political economy. Its material power and labour requirements had a profound impact on the development of South African capitalism and democracy, including, though by no means limited to the media, as an industry and as an institution. The opening chapter described how apartheid applied political power with economic intent and effect: legislation that regulated the residence, mobility and labour of the non-white population, and in particular the black African population, also secured the conditions for the reproduction of a cheap industrial work force. It is important to briefly discuss the origins and developments of the mining industry and its relation with labour. Doing so reveals how this sector developed into a highly concentrated industry, and how this tendency was mirrored in the South African press and in the economy as a whole.

Second, the example of the Anglo American Corporation - the leading mining corporation and subsequently one of the biggest diversified conglomerates in South Africa - also highlights the importance of large-scale capital across the South African economy, its influence in the political and legal realm and, in particular, the evolution of the press. The mining industry in general and the Anglo American Corporation in particular had a decisive influence on the founding and evolution of the English-language press. The emergence of this constellation of capital, political influence and the press also galvanized Afrikaaners to forge their own political instruments and newspapers in response, albeit with a much more explicit political and nationalist agenda than that of the Anglo-based groups. This gave the Afrikaan's press a more explicitly political and 
identity building role than its English counterparts. That distinction was crucial to the future evolution of the press, and continued to distinguish between an industry divided into major press groups on the basis of national identity and language.

Prospecting for diamonds and gold began in the late 1860s in South Africa's interior. This area was dominated by the Boer Republics of the Transvaal and Orange Free State which had emerged as a result of Boer ("farmer" in Afrikaans) dissatisfaction with British colonial administration. Within four years of the first diamond discoveries, the British had annexed the area and the largest diamond-producing mines in the world were established.

Originally, legislation limited the size and number of claims one person could hold (Innes 1984). However, as the diamond pits deepened, the demand for labour increased. This demand was met in part by the migratory populations resulting from imperial conquest and the dispossession of indigenous populations. African mineworkers from a very early stage took advantage of such shortages to demand better wages and working conditions, with varying levels of success (Innes 1984). Indeed labour would prove to be a central issue around which the diamond and later gold mine-owners would seek government assistance.

Large merchants based in Europe controlled the international diamond market. When it collapsed as a result of the global economic crisis of 1873 , South African claims began to merge. The resulting joint-stock companies, or mining-finance houses, were precursors of the group system that would come to characterise the South African economy. 
In terms of gold mining, large-scale production began after the discovery of the gold-bearing reef on the Witwatersrand in 1886. Unlike diamonds, a luxury commodity requiring strict control of supply, the market for gold was unlimited - provided that sufficient labour and capital could be secured. Overseas investment was sought by promising high return for low risk; a low-cost structure could achieve the former, while spreading the risk over a number of ventures could achieve the latter (Innes 1984). The group-system could accommodate both of these objectives; hence the organization of gold production quickly took the form of the mining-finance house, enabling the diamond magnates to secure the necessary capital from Europe to purchase as much "potentially gold-bearing ground" as possible (Innes 1984: 47). Tensions arising from the increased power of European mine-owners within Boer-administered territory eventually culminated in the Second Anglo-Boer War (1899-1902).

So it was that by the 1890s, six groups already dominated the gold industry. The magnates driving these groups included Cecil Rhodes, Hermann Eckstein, Julius Wernher, Alfred Beit, and Barney Barnato. All of these figures eventually became major shareholders in the Argus Printing and Publishing Company between its inception in 1888 and 1910 . While the development of the press industry will be dealt with in more detail in the next section, it is important to note that the organization of the industry largely followed the pattern of concentrated capital and centralized production previously established in the mining industry's group system. Indeed, much of South Africa's economy took this shape. And in this specific case, key figures in the gold and diamond mining industry became key figures in the newspaper industry. In other words, major sections of the South African press did not develop as independent agencies, as liberal 
theories of the $4^{\text {th }}$ estate would have it, but as adjuncts of the most important centres of capital.

\section{The Rise of Anglo American}

By 1916 the Oppenheimers, through Consolidated Mines Selection Company, were in control of the richest gold-bearing areas in what would become the richest gold field in South Africa. This was its potential; sufficient capital was required to make it happen. War-torn Europe was not in a position to provide such capital, so the Oppenheimers turned to America's capital markets. One third of Consolidated Mines was owned by German interests, a somewhat undesirable association considering that then-Prime Minister Smuts had led South African into WWI against Germany. The group decided to float a new company for the purpose of securing American capital, and in September 1917 the Anglo American Corporation of South Africa was created. The board of six directors was composed of two representatives of American financial interests, JP Morgan and Company and Guaranty Trust, one representative of an American mining combine, the Union of South Africa's first Minister of Finance, and a representative of the National Bank of South Africa who was also a South African MP (Pallister et al 1987). Company chairman, Ernest Oppenheimer, sought the express support of Prime Minister Smuts to register the company in South Africa, framing the issues as one of economic nationalism (Pallister et al 1987).

In 1925 the state introduced the Diamond Control Act, which gave it sweeping powers over the sale and production of diamonds. Ernest Oppenheimer, an MP at the time, used his position in parliament to secure an amendment to the bill that in any 
dispute, preference would go to local purchasers. This amendment effectually gave exclusive preference to the locally-registered Anglo American Corporation, since the De Beers companies - the leading syndicate at the time - were all registered abroad. By the end of 1929 De Beers was bought out by Anglo American, making the latter the biggest group in the mining industry as a whole.

\section{The English Press}

Thus far, then, we can see that much of South Africa's industrialization was driven by the requirements of the mining industry and the particular economic and political conditions in which it operated. Of particular importance is the fact that the leading mining firm, Anglo American, became the largest newspaper publisher by the $1960 \mathrm{~s}$. McGregor refers to Anglo American's association with the press as "an incidental acquisition", established when Anglo American gained control of the Argus Newspaper group as part of a deal that was designed mainly to acquire two rival mining giants - Johannesburg Consolidated Investments and Central Mining Investment Corporation Limited - in 1960 (1994: 12). Both companies had been the Argus newspaper publishing group's largest shareholders since $1910^{5}$ - demonstrating that the historical association between mining capital in general and the English press was strong and enduring up until this point in time.

These transactions illustrate how the broader processes of corporate and capital restructuring shaped the development of the English press. In this regard, two specific processes stand out as having been especially important: integration and diversification Integration can be horizontal, where a firm acquires units at the same level of production:

\footnotetext{
${ }^{5}$ Central Mining, the largest shareholder with a holding of $26.94 \%$, was listed as "C Distil and EA Walters". The address of the latter was given as "Corner House," and the Corner House Group consisted of Central Mining, Wernher Beit \& Company, and H. Eckstein \& Company (McGregor 1994; Fraser 1987).
} 
that is, by establishing a chain of newspapers. Horizontal integration extends control within a particular sector and can increase economies of scale through shared resources. Vertical integration, in contrast, exists when a firm acquires units at different levels of production, from extraction of raw materials through to the distribution of the final product: an example would be a newspaper publisher who owns not just the printing press and employs journalists, but also owns forests and pulp and paper mills at one end of the supply chain and newsstands at the other. Vertical integration strives to exercise control over all stages within an industry, thereby reducing a firm's vulnerability to fluctuations in the supply and price of essential materials and services (Murdock and Golding 1973). Both processes are a way of rationalizing production, and both can be accomplished via mergers and takeovers. Both processes were also very prominent in the development of the South African press - as we will see shortly.

Diversification is another important process and can be defined as a strategy where a firm acquires holdings in other sectors different from its main line of business (Murdock and Golding 1973). A prime example would be Anglo American's diversification into the press business through its acquisition of Johannesburg Consolidated and Central Mining. Diversification enables companies to "hedge their bets" by counteracting possible or actual loss in one sector with profits from another.

Anglo American achieved horizontal integration with its eventual domination of the mining industry. The press holding that Anglo American acquired - the Argus group - was itself a product of diversification. South African mining groups first expanded into the press industry in 1881 when mining magnate Cecil Rhodes provided Frances Dormer with financial backing to buy the Cape Argus from printers Saul Solomon \& Company. 
At the time, Solomon was a prominent Cape parliamentarian and Rhodes himself had just won a seat in the same parliament. Rhodes had entered politics hoping to influence the colonial administration to build a railway, linking the land-locked Kimberley diamond mine in Orange Free State to the British-controlled ports. The Cape Argus deal ensured ample coverage of his speeches and sway public opinion (Meredith 2007). At the very least, the deal further harnessed the development of the press in South Africa to centres of large-scale capital and political ambitions. Consolidation was also reinforced by the fact that technological advances in the printing press had massively increased the start-up costs for a newspaper. South Africa's mining magnates had the capital and the motivation to invest and Rhodes' beneficial association with the Cape Argus demonstrated it to be an adequate investment for surplus mining funds (McGregor 1994).

So it was that in 1888 Cape Argus merged with The Star, a Johannesburg paper begun the previous year, and began a process of horizontal integration within the press industry. Both were to be held through the newly incorporated Argus Printing and Publishing Company Limited. Among the major signatories to the company's articles of association, Cape Argus owner-editor Dormer topped the list with a shareholding of 23.71 percent, followed by mining magnates Hermann Eckstein at 9.35 percent and Joseph Robinson ${ }^{6}$ at 8.94 percent. In addition to the capital provided to Dormer, Rhodes' company, Goldfields of South Africa, is listed with a shareholding of 3.74 percent (McGregor 1996: 5). Innumerable share transfers occurred in the following twenty years

\footnotetext{
${ }^{6}$ Robinson's principle interests were held in the Standard Diamond Mining Company which, by 1886 , was one of four powerful companies dominating the Kimberly diamond mine; in that year Barney Barnato bought out Standard and one other of the four in his race against Rhodes to gain monopoly control of the country's diamond production (Meredith 2007: 52, 155).
} 
- also a significant time of integration in the mining industry - so that by 1910 the major shareholders were:

Table 2.1 Argus Printing and Publishing Major Shareholders 1910

\begin{tabular}{|l|c|}
\hline & $\%$ \\
\hline C Distil and E.A. Walters (read: Central Mining) & 26.94 \\
\hline Johannesburg Consolidated Investments & 19.51 \\
\hline $\begin{array}{l}\text { Otto Beit (brother of Alfred Beit, one of Central Mining's co-founders } \\
\text { and financial advisor to Rhodes) }\end{array}$ & 9.55 \\
\hline Robinson (mining magnate) & 5.55 \\
\hline S.B. Joel (mining magnate) & 4.77 \\
\hline the estate of Rhodes & 3.95 \\
\hline Sir Edward Dunning & 3.64 \\
\hline
\end{tabular}

Source: McGregor (1996)

By 1926 the major shareholders were listed as:

Table 2.2 Argus Printing and Publishing Major Shareholders 1926

\begin{tabular}{|l|c|}
\hline & \% \\
\hline Central Mining & 34.27 \\
\hline Johannesburg Consolidated & 19.98 \\
\hline Beit & 9.45 \\
\hline Joel & 9.09 \\
\hline Robinson & 5.46 \\
\hline
\end{tabular}

Source: McGregor (1996)

In essence, the structure of ownership in the mining industry had been replicated in the structure of the newspaper industry. Here, in classic Marxian political economy terms, the "economic base" did appear to strongly determine the "superstructure" (that is, the realm of ideas represented by the press).

In 1931, Anglo-French enmity led some of the Argus shareholders to create the Argus Voting Trust. The main purpose of the Trust was to ensure that the unregistered 
holders, believed to be dissatisfied French shareholders, who accounted for about 57.5 percent of Central Mining - itself the largest shareholder in the Argus Publishing company - would not be able to take control of Central Mining, and through it, Argus. The Trust was thus formed to ensure that Central Mining's shares in the Argus Company "would be in the hands of persons sympathetically disposed to the British Control of the Corporation and to the persons at that time controlling the corporation and the Argus" (quoted in McGregor 1996: 7). Suitable buyers were sought who would invest but place voting power in the trustees in perpetuity; by $1953,49.44$ percent of the company's total issued share capital was held in this manner (McGregor 1996a).

While Anglo American was achieving horizontal integration within the mining industry, Argus had been pursuing the same strategy in the newspaper industry, steadily increasing its stable of newspapers and forging a national chain of dailies (McGregor 1996a). ${ }^{7}$ Anglo American was also pursuing a strategy of vertical integration and by the 1960s it controlled the mining industry "from the banks that supplied the loans to the plantations that made the pit props" (Pallister et al 1987: 8).

In terms of vertical integration in the newspaper industry, by the end of the $1960 \mathrm{~s}$ Anglo held a minority interest in the Union Corporation Mining Group which in turn controlled South African Pulp and Paper Industries, then dominant in the paper industry. In 1967 Anglo formed the Mondi Valley Paper Company which began production of newsprint and other papers in 1971 (Pallister et al 1987).

Clearly, then, mining capital had financed the emergence and consolidation of South Africa's first major newspaper group, Argus Printing and Publishing. Initially this occurred through the backing of mining magnates. Further consolidation among these

${ }^{7}$ See Appendix 1 for newspaper ownership according to press house. 
magnates was reflected in the consolidation of Argus shares under Johannesburg Consolidated Investments and the Argus Voting Trust, with the largest percentage of shares ultimately falling under the ownership of the Anglo American Company in 1960. Indeed, from that point until 1994, the Anglo American Company held the dominant stake in Argus, at 40 percent. The acquisition not only solidified Anglo American's position in the mining industry but made it the biggest newspaper publisher in the country. Although originally blocked by the government, by 1971 Anglo American came to control a 31 percent stake in SAAN - the second largest newspaper publisher in the country. By1981 this share had increased to 40 percent (Louw 1995; McGregor 1996). In short, by the early 1980s Anglo American owned and controlled the two most important English language press groups in South Africa. These media acquisitions assured Mondi a market for its newsprint, and in 1977 the company acquired further interests in timber and paper manufacturing through South African Board Mills. All of these changes were clear examples of, simultaneously, diversification as well as horizontal and vertical integration. The Anglo American Company was thus a massive diversified conglomerate that, in addition to its core mining assets, operated the country's major newspaper chain. By 1990/91 it laid claim to 67 percent of daily newspaper circulation (Argus contributing 58 percent to this figure) and 80 percent of an estimated 1.3 million readers (Switzer 2000: 44; Bauer 2009: 4).

The Anglo American Corporation thus served as the leading example of the country's industrialization and demonstrated the significance of large pools of Englishdominated mining capital in the development of the South African political economy in general and of the press specifically. Recognizing the impact of politics on profits and 
vice versa enabled Anglo American to gain control of the diamond industry and was the motivating factor behind the establishment of the Argus Voting Trust. This point is likewise central to understanding the rise of the Afrikaner nationalism and the establishment of a press capable of arguing and circulating its cause.

\section{The Afrikaans Press}

In the aftermath of the Second Anglo-Boer War, as English mining magnates consolidated their interests and added the English press to their stable, the Afrikaner population was undergoing changes that would lead to the establishment of an Afrikaans press. This press would have deep ties to Afrikaner-dominated capital, political parties, and the project of forging a national Afrikaner identity with a secure base of capital at its root. Differences within the Afrikaner population resulted in schisms in Afrikaner nationalism and in the party that represented it (the National Party). The Afrikaans press, as a mouthpiece for this nationalism, would likewise develop along these fault-lines.

The following discussion of the Afrikaans press will demonstrate how this group was fundamentally shaped by the aims and values of a more specifically political project - not, however, to the exclusion of profit. Of course one cannot be exact with respect to the quantum between profits and politics, but it can be said that the relative weight of these two dynamics in the English and Afrikaaner press were mirror opposites of the other. Or in other words, while the English press was geared mostly toward profit and capital enterprise, the Afrikaaner press was a more explicitly political vehicle immersed in an overt political project. Indeed, in the latter case, nationalism was put to the cause of mobilizing political and economic power, although the relative weakness of this latter 
goal - that is, reproducing economic power - eventually caused a decisive split among Afrikaner nationalists and the press houses that supported them.

At the end of the Second Boer War, differences amongst the Afrikaner population can be seen in the economic status of northern inhabitants relative to those of the south. The fall of the Boer Republics witnessed an influx of white workers, largely Afrikaners, into urban areas. Between 1900 and 1926 the proportion of northern Afrikaners living in towns grew from 10 to 41 percent (Muller 1987: 119). They were relatively poor compared to the Afrikaners of the Cape, and shared an experience of war and devastation unknown to their southern counterparts who had generally prospered in the Cape Colony. The latter counted wealthy wine farmers and prosperous urban professionals among their ranks and represented a growing industrial and financial capitalist class. In contrast, the northern Afrikaners would largely join the white working class, with a small group of them forming a petit-bourgeoisie.

In terms of similarities, Afrikaners held their roots in common and, more importantly, they all had an interest in asserting control over the non-white population. In political terms, extending the franchise to this population would render them a minority in the land of their birth. Religious beliefs about the inherent inferiority of black South Africans also contributed to the rejection of any extension of political rights. On the one hand, the growing Afrikaner industrial and financial capitalist class and the petitbourgeoisie could benefit, as the English had, from a continuous and controlled supply of cheap labour. On the other hand, maintaining this labour as cheap and retaining the colour bar in turn benefitted white workers in the form of job security and relatively high 
wages. These common interests, then, were mobilized by southern Afrikaners into an overarching nationalism aimed at gaining the economic and political upper hand.

Retaining and securing white Afrikaner political control and increasing Afrikaner economic power thus formed the base of the Afrikaner nationalism that emerged shortly after union in 1910. In the elections of that year Afrikaners formed the largest part of the predominantly white electorate. The South African Party, an amalgamation of three regional Afrikaner parties, won just over half the votes and General Botha became Prime Minister.

Meanwhile, labour unrest and the influx of white workers into urban areas continued. Mine-owners were faced with having to balance the racial division of labour with the (always) over-arching imperative of controlling costs and maintaining high profit. In 1913 a small-scale white miners' dispute escalated into a general strike and riots and Botha's government responded with martial law. Elements of his party perceived this reaction as heavy-handed and favourable to English mine-owners over white mine-workers, many of whom were Afrikaners. Disagreement precipitated a split in the party, with a faction, led by General Barry Hertzog, leaving to form the National Party.

Newspapers were integral to the nascent nationalist politics of the time. In 1915, two years after the formation of the National Party, two Afrikaans papers that would soon come to have a significant political influence in the country made their debut: $D e$ (later Die) Burger and Ons Vaderland. Die Burger was introduced as the flagship paper of Naspers, which was incorporated May 1915 with the financial backing of Cape wine farmers and professionals; Dr. DF Malan was its first editor. In September of the same 
year, Malan was elected the first leader of the Cape National Party. Die Burger thus became "the major voice of [southern] Cape nationalism," which in turn came to be associated with Afrikaner capital investment and accumulation (Muller 1987: 121). Also in September 1915, Ons Vaderland was set up in Pretoria, in the (northern) Transvaal. Its founding company, the Northern Printing Press Company Limited ${ }^{8}$, counted then-Prime Minister General Hertzog among two of its three controlling shareholders (Muller 1987). In 1931 the company was incorporated into Afrikaanse Press Limited ${ }^{9}$, all the signatories of incorporation save one being members of Hertzog's Cabinet (Muller 1987). Although with significant political power, these shareholdings still represented smaller pools of capital than that which was embodied in the English press. In the north, and to a lesser extent, economic mobilization was spearheaded by the Afrikaner Brotherhood ${ }^{10}$, an association of Afrikaners originally with less capital than their southern counterparts that nonetheless became the eminent force behind Christian nationalism through the apartheid era.

Both papers supported Hertzog's government to varying degrees with Ons Vaderland being the most aligned. However, Hertzog's loyalties soon came to be questioned. White miners' wages, reduced by the mines during the first Smuts government (1919 - 1924), never returned to pre-1922 levels under Hertzog's rule (1924

\footnotetext{
${ }^{8}$ Noordelike Drukpers Maatschappij Beperkt

${ }^{9}$ Afrikaanse Pers Beperkt

${ }^{10}$ Afrikaner Broederbond. The actual power and imaginative force of the "Bond" as it was commonly known is integral to understanding the organization of Afrikaner nationalism, particularly once the National Party came to power in 1948. It took on the trappings of a secret society, with a front organization (Federasie van Afrikaanse Kultuurverenigings or Federation of Afrikaans Cultural Organizations), and a membership of government officials, including Prime Ministers and Presidents, judges, lawyers, members of the defence force and police, businessmen, Dutch Reformed Church dominees, university professors, etc. See O'Meara (1983); Muller (1987); Waldmeir (1997); Krog (2000); Hoschild (2007); van der Westhuizen (2007). I do not go into depth about it here in preference for more verifiable links between capital, nationalism and political economic power.
} 
- 1939) (Muller 1987). Despite the Mines and Works Act of 1926 which extended job reservation for whites across industries and the country, Hertzog was increasingly perceived by the Cape nationalists as having sold out to the "imperial" mining capitalists (Muller 1987). This impression was compounded when in 1934 Hertzog's National Party joined with Smuts' South African Party to form the United Party. ${ }^{11}$ Of the provincial parties, the Orange Free State and Transvaal National Parties joined the United Party, while the Cape National Party followed Malan into his Purified National Party ${ }^{12}$ (Muller 1987).

Ons Vaderland and Afrikaans Press Limited had little choice but to stick with Hertzog and the new alliance. Naspers' Die Burger followed Malan and the Purified National Party. Indeed, the chairman of Naspers, WA Hofmeyer, was also organizing secretary of the Cape National Party (Muller 1987). Hofmeyer had helped form and chaired the South African National Trust Insurance Company ${ }^{13}$ and its subsidiary, the South African Life Insurance Company ${ }^{14}$, both of which strove to mobilize Cape Afrikaner capital. The South African Life Insurance Company was Naspers largest shareholder (McGregor 1996a). This is one example of the Afrikaner press's deepening ties to Afrikaner-dominated capital, political parties, and the project of forging a national identity with a secure base of capital at its root.

The Purified National Party was left with no paper in the Transvaal with which to voice its interests. Hofmeyer thus spearheaded the move to establish a new publishing

\footnotetext{
${ }^{11}$ Smuts' policies, including taking South Africa into World War I on the side of Britain, had factored into the break that had resulted in the formation of the National Party in the first place.

${ }^{12}$ Gesuiwerde Nasionale Party or GNP

${ }^{13}$ Suid-Afrikaanse Nasionale Trust Assuransiemaatskappij or Santam

${ }^{14}$ Suid-Afrikaanse Lewensassuransiemaatskappij or Sanlam
} 
venture geared towards the north. To this end, Voortrekker Press ${ }^{15}$ was registered in 1936 with Hofmeyer as chairman, and Malan and JG Strijdom, leaders of the Cape and Transvaal Purified National Parties respectively, as board members (Muller 1987). The company's first paper, Die Transvaler, was edited by social psychology professor HF Verwoerd. Verwoerd was from the Cape; his strong editorial views against English, and in particular Jewish, finance and mining capital ended up suiting Strijdom and antagonizing Hofmeyr, who resigned as company chairman in 1938 (Muller 1987). Verwoerd's views likewise resulted in an advertising boycott, which obliged Voortrekker Press to approach Hofmeyr for help. Hofmeyr offered to buy their shares at a much reduced price and Strijdom refused (Muller 1987). Around this time, the South African Life Insurance Company, under Hofmeyr's lead, began approaching Transvaal farmers for investment capital. At the time, Cape agriculture did not appear to be suffering from the depression as their northern Transvaal counterparts. As a result, latter group came to distrust both the finance and political power of the south and its press, as represented by Naspers (O’Meara 1983; Muller 1987).

Notwithstanding their significant differences, leading Afrikaner entities in the north and south came together in 1939 to push for a unified Afrikaner nationalism. Hertzog had once again joined forces with Malan in a Reunited National Party. ${ }^{16}$ In October of that year the (northern) Afrikaner Brotherhood and the (southern) South African Life Insurance Company convened an Economic People's Congress. ${ }^{17}$ The interests represented by these respective groups "were rhetorically papered over by [the]

\footnotetext{
15 Voortrekkerpers

${ }^{16}$ Herenigde Nasionale Party or HNP. Hertzog and his supporters left the United Party over Smuts' decision to take South Africa into World War II against Germany.

${ }^{17}$ Economic Volkskongress
} 
slogan of "People's Capitalism"18 - a strategy aimed at achieving "political and economic power for the "volk'" (Muller 1987: 126). Significant differences of interest persisted and were voiced but were largely contained by the dominant interests behind the Reunited National Party such that, by the 1943 elections, the party was recognized as the leader of Afrikaner nationalist politics (Muller 1987). The National Party came to power in 1948, with three successive Naspers men at the helm: Malan (1948 - 1954), Strijdom (1945 - 1958) and then Verwoerd (1958 - 1966).

\section{Perskor}

It was around this time that the other Afrikaans press house, Perksor, was started up. The origins and evolution of this group demonstrate how groups with seemingly at-odd interests - this time right-wing Afrikaners and English businessmen - could make common cause, at least for a time. In 1947 the editor of Afrikaner Press Limited's Vaderland Willem van Heerden left over a disagreement with management, along with the advertising manager Marius Jooste; together they established Daybreak Press Limited $^{19}$ (Muller 1987; McGregor 1996). At that time a small but powerful group known as the Ox-wagon Guard ${ }^{20}$ controlled a press corporation called Perskor, which, upon incorporation into a larger entity ${ }^{21}$, contributed start-up capital to Daybreak Press (Muller 1987; McGregor 1996). The remaining capital was solicited from English business and mining concerns, including Strathmore Investments/Exploration Limited. Strathmore, comprised of three shareholders, J Scott (with controlling interest), JC

\footnotetext{
${ }^{18}$ Volkskapitalisme

${ }^{19}$ Dagbreekpers Beperk

${ }^{20}$ Ossewa Brandwag or OB; a reference to the means by which the Boers undertook the Great Trek, the OB was an ultra-right-wing militant group founded in 1938.

${ }^{21}$ Onafhanlike Pers van Suid-Afrika or OPSA
} 
McIntyre and CW Roper, eventually obtained controlling shares in Daybreak Press (Muller 1987; McGregor 1996). The Articles of Association of Daybreak Press, however, were meant to ensure political neutrality and that Afrikaans and English content, control and management of its newspapers was equally shared (Muller 1987; McGregor 1996).

For a time it seemed that a non-nationalist Afrikaans press grouping might be possible, and in 1951 Jooste sought to form a controlling subsidiary within the company. The result was Daybreak Trust (Pty) Ltd with Scott, McIntyre, Roper, Jooste, van Heerden, and Professor LJ du Plessis as controlling shareholders (Muller 1987; McGregor 1996). But the marriage did not last: in the 1953 general elections, the group's Sunday weekly Dagbreek en Sondagnuus openly supported the National Party, in violation of the articles of association (Muller 1987; McGregor 1996). Scott wanted to leave the association and Jooste bought his and Roper's shares (Muller 1987; McGregor 1996). Daybreak Trust (Pty) Ltd was renamed Daybreak Trust, with five of the eight original trustees - Jooste, van Heerden, du Plessis, Strijdom, Verwoerd and McIntyre staying on board. Through subsequent mergers Daybreak Trust remained the controlling group within what eventually became known as Perskor.

These developments in both the English and Afrikaans press took place alongside the development of South Africa's secondary industry. This was most clear in the case of the English press and its relationship to the primary sector of mining, though no less true for the context in which Afrikaans press and politics played out. In the decade following WWII the vast majority of manufacturing establishments were small and in much the same position as the earliest mine-owners: they required a system of strict labour control 
that prevented African wage rates from rising while securing a sufficient labour supply. The resistance of black workers was increasingly hostile and organized. By the elections of 1948, reform of the segregated workforce was on the table.

One solution, as far as large-scale English dominated capital was concerned, was to remove the colour bar and employ African workers in jobs traditionally reserved for white workers, but at lower rates of pay, again to maintain profit margins. Such reform, limited as it was, was adopted by the United Party in 1948, but largely rejected by the predominantly white electorate. Instead, the National Party came to power and began to construct the legislative and coercive apparatus that would control the African population as a cheap industrial labour force and secure the privilege of the white working class. From this point onwards the Afrikaans press largely become a mouthpiece of the government, while the latter set about constructing and strengthening the legislative and coercive foundations necessary for maintaining and increasing Afrikaner political and economic power and privilege.

Because apartheid was at once a political and economic ideology that affected black South Africans as citizens and as workers, black workers formed a crucial part of the general tide of anti-apartheid resistance. Notably, the mass action strategies employed in the 1950s involved boycotts and general strikes, designed to attack the economic foundations of apartheid. But by the 1960s politics and profit converged to quell the rising dissent while enabling the further concentration economic power. When police opened fire on unarmed protesters in Sharpeville in 1960, strikes and riots within the country and international condemnation ensued. The government declared a state of emergency, banned the ANC and the Pan African Congress and, in 1961, left the 
Commonwealth. Anglo American benefitted from the subsequent flight of capital by purchasing a wide range of industrial and financial shares on the Johannesburg Stock Exchange (Pallister et al 1987). The rest of the decade witnessed both the temporary political defeat of the liberation movement and an economic boom. Meanwhile, the country's demographics and the needs of capital shifted, necessitating a diversification from labour- to more skills-intensive work. Eventually, these changes precipitated a new generation of African journalism. The revived and revamped intellectual and cultural output would instigate a new wave of mass resistance that would impact the press industry as a whole. The next chapter will look at these developments. 


\section{Chapter 3 The Resistance and Alternative Press}

The increasing dominance of highly concentrated large-scale capital in key segments of the South African economy was a pivotal process in the political economy of the country and its press. It occasioned a growth in non-productive jobs, such as administrative and clerical work, that required a relatively small, stable, semi-skilled and skilled black workforce - and thus a gradual lowering of the job colour bar, and a more stationary, organized workforce with which employers could negotiate. This required a considerable change in government policy. These requirements and a growing black urban population contributed to the emergence of a sizeable black middle class (Burton 1987; Tomaselli and Tomaselli 1987).

To some press interests, a more permanent and relatively highly-paid urban black workforce represented an untapped audience. On the one hand, the black press that emerged was able to benefit, to a degree, from the cleavages between the Afrikaans and English press, where the relative openness of the latter helped develop a new cadre of black journalists and, eventually, black-run newspapers. On the other hand, this nascent commercial black press was subject to the fallout from competition within the English press, between the Argus and SAAN press houses. By the 1970s, the commercial black press was also influenced by a student-led non-commercial black press, co-operatively produced and inspired by Black Consciousness. This combination of factors in turn led to a third genre of publications in the mid- to late-1980s: the alternative press. This chapter will trace the emergence of this second generation of African journalism. 


\section{The Commercial Black Press circa $1930-1960^{22}$}

Generally, the press under apartheid did not represent those who had no formal recourse for addressing grievances in a just and meaningful way. Indeed, the grievances of the black majority were institutionalised - that is, normalised - to an extent that went some ways in nullifying any watchdog function in this regard. Censorship, both overt and covert, was broad and effective enough to handle, sometimes temporarily, more often insidiously, whatever dissent and criticism did surface.

But the press under apartheid - and the English-language press in particular - was concerned with representation as a matter of business - with paradoxical effect. Apartheid institutionalised white political and economic power which meant that whites by and large dominated the market sought by advertisers. On the other hand, a growing black urban population and the economy's changing labour requirements combined to produce a relatively highly-paid, stable, untapped demographic that was also highly politicized. Both the English and Afrikaans establishment press had "black papers", but the scope for "Black voice" in them varied significantly according to whether they were English-language or Afrikaans and sometimes even within different publications in the same publishing group.

In 1932 Bertram Paver, a white ex-farmer and owner of Bantu Press Ltd., introduced Bantu World, modeled after the British tabloid press. ANC member Victor Selope Thema was its editor. By the end of the year, half of the shareholders were black. Thema took a condescending view of African workers and a moderate editorial line; nonetheless, Bantu World reported on poor working conditions, argued for higher black wages, covered workers' efforts towards this end, and counted trade unionists among its

${ }^{22}$ See Appendix 1 for a list of titles by press house circa 1950. 
contributors (Limb 2000). The Argus Printing and Publishing Company acquired Bantu Press, and through it Bantu World, in 1933. Through this acquisition it gained control of what remained of the independent African press, including Imvo Zabantsundu and Ilanga Lase Natal, so that by 1945 it owned ten weekly African newspapers, with two more added by 1950 (Ukpanah 2005). Argus proprietorship brought with it access to largescale capital to underwrite the cost of newsprint, production and distribution, while horizontal integration - the creation of a newspaper chain - favoured the syndication of stories. The absorption of the independent African press under white-dominated capital brought about a shift from a relatively elite black press to a more popular mass press, wherein partisan political news was de-emphasized in favour of social news and leisure (Limb 2000; Ukpanah 2005). The increasingly repressive policies of the apartheid government after 1948 also contributed to this process. The Guardian, Torch, and Inkundla ya Bantu are the notable examples from this period of eventual inability to withstand the political power of the state or the economic power of the white-owned commercial black press.

The Guardian was set up in 1937 by "an eclectic group of young trade unionists, university professors, and disgruntled communists" (Zug 2000: 129). The non-racial weekly rose to prominence in the 1940 s as the leading voice of the liberation movement. By the 1950s it had become closely allied with the ANC, whose leaders served as advisors, fundraisers, sellers, and contributors to the paper. When the National Party came to power in 1948 the paper faced constant harassment with staff members watched, raided and arrested by the Security Branch. It was banned in 1952 and 1954 but reappeared each subsequent Thursday with a new title (Zug 2000). Suspended for five 
months during the 1960 state of emergency and heavily impacted by the concurrent banning of the ANC, the paper persisted. In 1962 it was once again banned and once again, it reappeared the following Thursday, this time as Spark. Spark was its final reincarnation; three months after it appeared the government placed almost its entire editorial staff under house arrest (Zug 2000).

Torch likewise succumbed to state pressure. Founded in 1946 and named after the Bolshevik's Iskra, it was generally considered the unofficial organ of the NonEuropean Unity Movement (Adhikari 2005). The weekly publication was originally distributed nationally, but the bulk of its readership was concentrated in Cape Town. Its main fare was local politics and education politics in particular, given the prominence of teachers within the Unity Movement. Like the Guardian, Torch was temporarily banned during the post-Sharpeville state of emergency. This weakened the paper, and it also ceased publication in 1963 when many involved in its production were served banning orders.

Inkundla ya Bantu, founded in 1938 by Govan Mbeki, was unable to compete with the economic clout of the white-owned commercial black press. In contrast to the radical, non-racial Guardian introduced a year earlier, Inkundla first circulated as a moderate African nationalist community paper in the port cities and rural areas of Eastern Cape and Natal. By the mid-1940s it had expanded its readership to Johannesburg and thus distinguished itself as the country's only African owned-and-operated national newspaper (Ukpanah 2005). Although its promotional advertisements continually stressed the need for Africans to have an African-owned publication, the paper eventually folded to the competition posed by the growing Bantu Press newspaper conglomerate. 
Inkundla ceased publication in 1951 and Govan Mbeki subsequently joined the editorial board of the Guardian (known as New Age at the time and subsequently as Spark).

In the absence of these papers, Bantu World became the dominant commercial black-focused paper. Argus renamed it The World in the mid-1950s. From this point through the sixties it is described as a "sex-sin-soccer rag" (Phelan 1987: 70). Reputation aside, its circulation between 1959 and 1968 rose from 11000 to 90000 (Tomaselli and Tomselli 1987: 47). Increasing literacy rates and a muffled and/or declining interest in political issues among black readers also help explain World's success, but the impact of a virtual absence of competition cannot be underestimated.

\section{Black Consciousness and the Student-led Press}

Thus subsumed by white-owned commercial media, the remaining black press gradually became discredited among an emerging and increasingly educated generation of activists. The rejection of the tabloid style of the World, however, helped to stimulate the rise of alternative publications and new forums for discussion, such as student newsletters and irregularly published annuals. Unlike the African nationalist and socialist papers that had preceded them, these publications did not include general interest news, opinion and entertainment but were instead closely associated with the Black Consciousness Movement (Switzer 2000).

Black Consciousness, similar to its American counterpart Black Power, promoted "anti-racist racism": its proponents took the racial identity constructed by white oppressors and used it as a basis of solidarity and struggle (Fredrickson 1995: 278). 
Rooted in ideas of double consciousness, Négritude, and Pan Africanism ${ }^{23}$, Black Consciousness emerged in the vacuum created by the banning of liberation leadership. It sought to contradict the black parochialism encapsulated in the Bantustan policy and in the accompanying state rhetoric of separate development along "traditional" tribal lines. It was critical of both white liberalism and the non-racialism of the ANC, arguing that true non-racialism would not come about until psychological liberation had been attained.

Students were at the forefront of the movement, perhaps none more well-known than Stephen Bantu Biko. Frustrated with their inability to achieve progress through the multiracial but white-dominated National Union of South African Students, black students formed the blacks-only South African Students' Organisation (SASO) in 1969. Biko was elected as their first president. The SASO Newsletter became one of the most significant publications in this phase of the black press (Switzer 2000). SASO attempted to expand the movement beyond students, establishing the Black People's Convention in 1971. The following year it launched Black Community Programmes [sic], piloting health clinics and health education, literacy, and homemaking classes in rural communities, with the aim of inspiring self-sufficiency as opposed to reliance on white aid and beneficence (Switzer 2000).

Black Community Programmes also introduced Black Viewpoint, an irregular annual edited by Biko. In its introductory issue Biko noted the "great vacuum in our literary and newspaper world. So many things are said so often us [sic], about us and for us but very seldom by us" (1972: Introduction). In terms of Black Consciousness, this had "created a dependency mood amongst us which has given rise to the present tendency

\footnotetext{
${ }^{23}$ As advanced in the writings of W.E.B Du Bois, Marcus Garvey, Frantz Fanon, Léopold Senghor, Aimé Césaire, Kenneth Kaunda, Julius Nyere, Kwame Nkrumah, and Anthony Lembede, among others.
} 
to look at ourselves in terms of how we are interpreted by the white press" (Biko 1972:

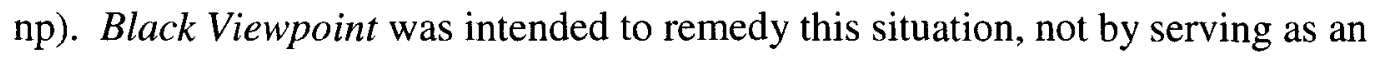
exclusive mouthpiece of any one segment of the black community, but by "pick[ing] up topics as they come and as they are dealt with by blacks in various situations" (Biko 1972: Introduction).

Black Consciousness thus became an anchoring frame of reference within a new type of press. It was also central to a rising tide of popular resistance that was both occasioned and compounded by pressures arising domestically and internationally. These included inflation, a recession, and the global oil crisis, as well as civil war and independence in neighbouring Angola, Mozambique and Rhodesia, in the latter half of the 1970s (Giffard 1980; Switzer 2000). What was bad news for the South African government made for good business as far as the establishment press was concerned. During the arrests and riots of the 1960 state of emergency, daily newspaper circulation soared by 58000 and 18000 copies amongst the English-language and Afrikaans papers, respectively (Giffard 1980: 90). South Africa's withdrawal from the Commonwealth in 1961, subsequent capital outflow, economic recession and then recovery towards the end of the 1960s were mirrored in more modest fluctuations in circulation figures (Giffard 1980). The overall growth of the economy from 1969-1974 meant continued growth for newspapers. However, when the economy took a downturn from 1976 onwards, the mainstream press did not follow suit: indeed, newspaper sales increased at rates not seen since 1960. 


\section{The Commercial Press circa 1970 - 1990}

The 1970s and 1980s witnessed frequent changes within the makeup of the newspaper market. These changes resulted not only from state censorship but from the interaction between this censorship and competition between the two English-language press houses. By the early 1980s, this competition had escalated into a "press war" - this despite the fact that by 1981 Argus owned a 39.9 percent stake in SAAN (Tomaselli and Tomaselli 1987). In hindsight, SAAN was doomed to lose given Argus' aptitude for playing fast and loose with the rules and for its ambivalent and opportunistic practices and policies as a press owner operating under the vagaries and constraints of the apartheid regime.

Amidst the growing influence of the Black Consciousness movement and the reemergence of labour and popular unrest, World, under the black editorial leadership of Percy Qoboza since 1974, became consistently and increasingly critical of the state. In addition, The Rand Daily Mail and The Sunday Express - both of which were published by SAAN - had also set themselves apart as anti-apartheid voices. These three papers rose to further prominence through their coverage of the Soweto uprising. ${ }^{24}$ At this time the townships, already hived off from white urban settlements, became a virtual no-go zone for white reporters. Black reporters working for World (Argus), Rand Daily Mail, and Sunday Express (both SAAN), however, were able to gain access. World photographer Sam Nzima took the iconic photograph that made international headlines:

\footnotetext{
${ }^{24}$ On 16 June 1976, unarmed school children took to the streets of Soweto to protest their instruction in Afrikaans and other shortcomings of their state-regulated education. Police opened fire and chaos ensued. By the end of the first day 23 marchers had been shot dead, with 93 more to follow over the next two days. Students in rural areas, homelands and townships across the country went on strike, and by February of the next year the official death toll stood at 575 . Some 14000 youth fled the country seeking to join Umkhonto we Sizwe ("Spear of the Nation"), the ANC's armed wing.
} 
Hector Pieterson's lifeless body being carried by Mbuyisa Makhubo, Hector's sister running alongside.

By mid-1977, the World in particular had risen to prominence. It became the country's largest daily with a circulation of 200000 (Phelan 1987). Justice Minister James Kruger warned Qoboza that the paper would be closed, which it was on 19 October 1977, along with its weekend edition, Weekend World. Qoboza and his news editor were detained under the Terrorism Act. After the closure of World and Weekend World, Argus filled the gap left in the market by elevating a small weekly, Post, to the status of a daily with a weekend edition, Sunday Post. In October 1980 Post journalists went on strike for two months; black editors did not initially participate, but did so after management threatened to call in the police (Independent Newspapers 1997). During this time Joe Latakgomo, in order to avoid the expiration of their licence, produced a 48-page pamphlet with the name of the Post; the Supreme Court ruled that this did not suffice. When Argus applied for re-registration, it was informed that if resumed, the paper would be banned. Argus then launched Sowetan (1981), a daily paper employing many of the journalists who had worked on World and Post.

\section{Selling black audiences and the demise of SAAN}

State incursions into the SAAN stable of papers were considerably worse. The group had attempted, unsuccessfully, to promote the idea of an integrated consumer public, based on income as opposed to race, to advertising agencies (Tomaselli and Tomaselli 1987). Within the group, the Rand Daily Mail and the Sunday Express had risen to prominence for their anti-apartheid stances, which garnered them increasing state attention. In this 
context of insecure revenue and increased state harassment, the Information Scandal, also known as "Muldergate" (after then Minister of Information Dr. Connie Mulder), unfolded. The fall-out of this scandal and the press war that followed would see SAAN absorbed into the Argus group and latter's ultimate rise to market leader.

Beginning in 1972 the government launched a concentrated and covert effort to secure more favourable press, domestically and abroad. It used funds diverted from the defence budget which, under the Official Secrets Act, was closed to public scrutiny. Domestically this covert plan involved the attempted take-over of the SAAN group. Businessman Louis Luyt, a front man for the National Party, made an offer to buy SAAN at twice its share value, and doubled the offer again when the original was rejected (Giffard 1990). In response to this hostile take-over attempt, Harry Oppenheimer's sonin-law and Johannesburg Consolidated Investment's Chair Gordon Waddell, along with other businessmen, set up the Advowson Trust, which they then used to purchase the shares that Luyt had bid on (Louw 1995; Horwitz 2001). This was in addition to the 30 percent in SAAN already held by Argus, which meant SAAN was safe from takeover, at least by Luyt.

Luyt then launched the pro-government, English-language tabloid The Citizen in September 1976 - in direct competition with The Rand Daily Mail for Johannesburg's morning market (Giffard 1990). The Citizen managed to attract many of the Mail's more conservative white readers, leaving the latter with a mostly black readership - one in which advertisers were not interested. The Mail was weakened by the subsequent loss in revenue. Nonetheless, it was the Mail, along with the Sunday Times and Sunday Express (all three SAAN papers), that began investigating rumours of government involvement in 
The Citizen, after the latter suggested that student-leader Biko, who had died in police custody, had committed suicide by banging his head against a wall.

Ironically, it was a government-appointed inquiry that ultimately revealed the Information Department's subterfuge. Tasked with investigating violation of exchange control regulations, Judge Anton Mostert uncovered the Swiss bank loans used by the Information Department to fund its propaganda efforts. Despite then Prime Minister Vorster's attempts to block him, Mulder, the Minister of Information, backed by the courts, announced the findings. Mulder and Vorster both resigned. Vorster's successor, PW Botha, commissioned an inquiry that reinforced the conclusions of the earlier findings that both men had willingly participated in and condoned the corruption.

The financial pressure and Advowson Trust buy-out occasioned by the Information Scandal, along with further financial restructuring, meant that Argus became the largest single shareholder of $\mathrm{SAAN}^{25}$, giving Anglo American de facto control of both English press groups after 1976. By 1981 Argus owned a 39.9 percent stake in SAAN. However, despite the fact that Anglo American had the dominant ownership stake in both of these press houses, the competition between the two newspaper groups not only continued but escalated into a "press war" (Tomaselli and Tomaselli 1987). Ultimately, this press war would culminate in the closure of the most stridently antiapartheid mainstream papers. It would also catapult the Argus stable to the position of market leader, once and for all.

Whereas Argus and SAAN had agreed ${ }^{26}$ to split the market, with Argus taking the evening weekly papers and SAAN the morning and Sunday papers, by the early-1980s

\footnotetext{
${ }^{25}$ Through its majority stake in Johnnies Industrial Corporation, known as Johnnic.

${ }^{26}$ Since the $1920 \mathrm{~s}$
} 
things changed entirely (Tomaselli and Tomaselli 1987; Republic of South Africa 1998). Argus introduced Saturday morning editions of some of its weekly evening papers. The Star, for example, was introduced into the Saturday morning market as the Sunrise Star; it included a property supplement that offered massive discounts on advertisements. The SAAN's Sunday Express, which had dominated the estate agency market, lost almost all its property advertisers. The Saturday edition of SAAN's Rand Daily Mail was also impacted and SAAN responded by cutting the paper's price and increasing its size, which boosted its readership by 56000 but cost the company R2 million extra (Tomaselli and Tomaselli 1987).

Struggling to stay afloat, SAAN attempted to fill the market gap left by the banning of Weekend World and Sunday Post, discussed earlier. Together with Jim Bailey, the group launched Golden City Press in 1982, the first national Sunday newspaper aimed at the black market (Tomaselli and Tomaselli 1987). Originally formatted after the tabloid style of the 1950s, Golden City Press lost money under Bailey's management. It was subsequently turned around when a SAAN executive took over and shifted the paper's focus to include a prominent focus on soccer and horse racing. By November 1982 its circulation surpassed that of the Argus' Sowetan. But the success was not to last. When Bailey refused to resign as executive manager, SAAN withdrew its backing, and the paper was closed by the end of January 1983. Less than a month later, Bailey launched an identical publication with the new name City Press; a year later Qoboza, formerly employed by Argus and detained by the state, was recruited to become its editor. Financial difficulties continued, however, and in 1984, City Press, Drum, and another "black" magazine, True Love, were sold to Naspers (McGregor 
1996a). The publications were originally offered to Perskor, their printer, but the press house was unable to raise sufficient capital.

SAAN continued to lose money, with Rand Daily Mail and Sunday Express in particular trouble. The group hired two consultants from the London-based Financial Times who suggested that the Rand Daily Mail tailor its product to its "dual market [of] businessmen and blacks" (Tomaselli and Tomaselli 1987: 81). The consultants found that between 1976 and 1983 the ratio of black to white readers had shifted from 43:57 to $72: 28$ percent; the apartheid logic of the advertising industry at the time concluded that the Rand Daily Mail "had 'two markets' [but] dominance of neither" (Tomaselli and Tomselli 1987: 82). In 1985 both the Mail and Sunday Express were closed as part of restructuring; the up-market Business Day was created to replace them. As part of this restructuring SAAN was renamed Times Media Limited in 1987.

There were suggestions, however, that the closures were related to the attempt of the four press groups, English and Afrikaner, to gain a piece of the emerging electronic media pie (Tomaselli et al 1987, Louw 1995). Television was only introduced to South Africa in the mid-1970s, with advertising beginning in 1978. By the mid-1980s the four press groups, through the Newspaper Press Union, were lobbying the government to privatize part of the state-run broadcast monopoly in the hopes of expanding into this new sector of the media industries. Their ambitions were partially realized when the subscription television service, M-Net, was launched in 1986 and its shares divided among the groups as follows: Naspers was given 26 percent along with management responsibility, and Argus, Times Media Limited (formerly SAAN), and Perskor were each awarded 23 percent ownership (Horwitz 2001). The groups were barred from 
broadcasting news but were able to use the new source of ad-spend to cross-subsidize their respective papers.

\section{The Alternative Press}

The closure of the Rand Daily Mail and Sunday Express gave rise in the latter half of the 1980s to an alternative press independent of both Argus and Naspers. Many of these publications were launched and staffed in part by former employees of the commercial press, whose papers had been closed down and who were generally disenchanted with how the mainstream media organizations were handling events and restrictions. The Weekly Mail, South, Indicator, Saamstaan, New Nation and Vrye Weekblad were all started during this time, and all were "voices which transcended the all-star liberal notions that reform would come from parliament" (Van Niekerk 1990: 40).

These papers attempted to democratise their newsrooms while maintaining their professionalism and meeting their production schedules (Switzer 2000). They were nonetheless subject to government publication regulations and increased scrutiny and surveillance due to their outspoken approach. As papers run on minimal start-up capital, and relying on a combination of foreign donations, subscriptions and tenuous sources of advertising revenue, they were particularly vulnerable to government action. Having an approach distinct from the mainstream press did not necessarily mean that they were mouthpieces of the liberation movement or any segment within it; the alternative press guarded their independence, wary of playing into the hands of any one faction, government or otherwise. This became difficult when, for example, atrocities by prominent struggle leaders came to light. Weekly Mail founder and co-editor Anton 
Harber $(1990 ; 2004)$ relates the difficult situation faced by those editors favourable to the liberation cause in early 1989 when allegations arose that bodyguards of Winnie Mandela had abducted four boys in Soweto: should they investigate the rumours that were becoming increasingly widespread? In so doing, would they unwittingly become part of a government smear campaign, as had occurred in the past? Was there room for a more independent position? Harber concludes: "I don't think in South Africa one can proclaim a simple, principled independence ... One has to balance the need to pursue change against the danger of becoming entirely subservient to a particular organization involved in change" (1990: 49).

Similar to the resistance press of the 1970 s, throughout the 1980 s protest and organization were assisted by various outlets such as left-wing academic and student journals, newsletters, and literacy texts produced by white-designated universities and by multiracial teams of activists; personal memoirs and revisionist histories that documented the liberation struggle; and literary and musical texts performed in townships and informal settlements (Switzer 2000: 44 - 45). As the liberation movement broadened from 1989 onwards, the mainstream white-owned commercial press increasingly ignored government restrictions to report regularly on the activities of the United Democratic Front, replaced by the Mass Democratic Movement in 1988 when the UDF and other dissidents were banned (Switzer 2000).

From 1990 onwards, the process of dismantling apartheid was underway and multi-racial democracy on the horizon. As a result, the overseas funding for the 
alternative press all but dried up so that by the early part of the decade many of these papers ceased publication. ${ }^{27}$

\section{Censorship, Principles and Profits}

By the 1980s, "there [had] been too many strikes, too many detentions of labour leaders, too many 'new dispensations' from the State for the capitalist press to ignore" (Burton 1987: 174). Did the commercial press indeed ignore these events beforehand? If so, which elements, and under what circumstances? What can be said of their handling of the tumultuous events of the 1980s? Or, as the Truth and Reconciliation Commission put it: "could the media also be said to have been directly responsible for gross human rights violations? To what extent were they responsible for the climate in which gross human rights violations occurred?" (Republic of South Africa 1998a: 165). This section examines some of these questions.

The role of the mainstream commercial press and in particular the Englishlanguage press, during this decade and under apartheid generally, is still contested. The Truth and Reconciliation Commission was the first independent body established by the new government and its work was contested from start to finish, including its attempt to shed light on the role of the media under apartheid. The announcement of a potential media hearing alone resulted in a major public debate, including submissions on what the scope of such a hearing should be and who should and shouldn't be involved in

\footnotetext{
${ }^{27}$ One notable exception was The Weekly Mail. In the early 1990s The Guardian in London began to invest in the paper and in 1995 became the majority shareholder; the paper was renamed The Mail \& Guardian. In 2002 The Guardian sold 87 percent of its share to Newtrust Company Botswana Limited, owned by Zimbabwean publisher and entrepreneur Trevor Ncube.
} 
undertaking research. ${ }^{28}$ The differences between the Afrikaans and English press were clearly evident. Crucially, the Commission's findings confirmed that the Afrikaans press, with very few exceptions, served as the mouthpiece of the National Party, and turned a critical eye on claims by the English press that it had opposed apartheid.

Few observers challenged the view that the government's repressive framework had had a severe impact on the press. Between 1950 and 1990 over 100 laws affecting media operations were introduced, including but certainly not limited to outright prohibition on the publication of subversive statements and/or statements of banned persons, and of reporting on police action or on what could be considered unrest (Republic of South Africa 1998a). As Independent Newspapers put it in its submission to the Truth Commission: "the laws were there, and editors had to decide what to do about them" (1997: Section 5 b).

Before the 1980s "emergency", laws by and large could be tested in court, provided one had the financial resources to do so; once the emergency was declared, censorship and closures, however, became more arbitrary and detention without trial was standard (Harber 1990). This is to say nothing of raids, newsroom spies, intimidation and harassment. ${ }^{29}$ Exploiting legal loopholes was one method of handling the repression, although Independent Newspapers (which acquired the Argus company in 1993) acknowledged that these efforts were "only made on any scale during the emergency regulations applied during the second half of the 1980s" (1997: Section 9 [14]).

As regulations became all-encompassing, law-breaking became unavoidable (Tyson 1990), although again there was a difference in the extent to which individuals,

\footnotetext{
${ }^{28}$ See Republic of South Africa (1998a) (Introduction); see also South African Press Association (1997a) and Freedom of Expression Institute (1997)

${ }^{29}$ For more extensive treatment see Republic of South Africa (1998a); also Nix (1995).
} 
editors, and management pushed the limits. Argus company editors interviewed for the Truth Commission admitted they could have gone further in testing what they could get away with. In their defense, however, they suggested that the barrier to doing so was that the line between acceptable and illegal actions was increasingly arbitrary (Independent Newspapers 1997). According to Harvey Tyson, former editor-in-chief of The Star, this situation led some newspaper people to turn to advocacy journalism against apartheid; on the other hand, "some 'old-fashioned' editors who aspired to balance and objectivity became the easiest to manipulate. Some editors never understood that the 'rules' were continually changing" (Tyson 1993 as cited in Independent Newspapers 1997: Section 5 b). Certain editors stood by their approach: "The purpose of a newspaper is to survive to inform. If it casts aside the fundamental principle of objective journalism and is seen to be one-sided, it would lose its readership base and its revenue and die" (Independent Newspapers 1997: Section 6 a). Similarly, Tyson argues that the Rand Daily Mail "had failed for managerial reasons, but it had also failed in its own editorial mission - its message was reaching only the converted" (1993 as cited in Independent Newspapers 1997: Section 6 a).

Critics of this view see it as trumpeting a hypocritical liberalism. The English press "failed dismally to reflect the feelings of 'ordinary' South Africans. They relied heavily on government sources of information, no matter how discredited they were, and made very little effort to obtain information from alternative sources" (ANC 1997: Section 3.3). Newspapers referred to those involved in the liberation movement as "terrorists" as opposed to "guerrillas"; stories written by black journalists were always questioned (Republic of South Africa 1998a: 175). According to Ameen Akhalwaya, the 
first black reporter to work on Rand Daily Mail, who helped launch the alternative Indicator: "The bosses also claim that black journalists, because of their commitment to writing from the so-called liberation perspective, couldn't be trusted to be objective ... The establishment newspapers bend the truth when it suits them. Many instances are distorted by omission" (1990: 53).

Criticism of the English "liberal" press must be understood in the context of the dominant place given to white politics and rivalries within South African history. Black students leaders of the 1970 s broke away from their white liberal counterparts because of the latter's inability to champion the cause of black liberation outside the confines of white politics. Hence the slogan coined by Biko for the South African Students' Organization: "Black man, you are on your own" (City Press 9 September 2007). "Gradualist" measures seen by liberals as important and necessary "stepping stones" were seen by others as anything from a cop-out to collusion (Tsedu and Qwelane as cited in Independent Newspapers 1997). English papers were hence subject to criticism in their extensive coverage of white politics. Their bias in this regard was exacerbated by interrelated legal and business considerations. Parliament - from which the vast majority of South Africans were excluded - was one of the few relatively censorship-free zones in the country (Republic of South Africa 1998a); this led some correspondents to conspire with MPs where the latter would read statements from banned activists that would then be reported on in the earliest possible edition of the paper, before it could be struck from the parliamentary record (Independent Newspapers 1997).

On the business side, there was the temptation to go for "the very easy story" (Thloloe 1990: 17) combined with a commercial disincentive to pursue certain "black 
interest subjects" for which there was no advertising to back up the space and apparently "low black readership to justify the placing of such stories" (Independent Newspapers 1997: Section 3 f). Not only did this view, wittingly or unwittingly, reflect the apartheid mindset; it contributed, along with censorship, to the homogenized representation of black opposition. As Thami Mazwai, then senior assistant editor of Sowetan argues, " $[\mathrm{t}]$ he picture that has been painted by many so-called progressive news editors . . is a picture that tells a story that in South Africa, blacks support only one particular organization, and that is the ANC. That is not true" (1990: 64). On the other hand, the government exploited (and instigated ${ }^{30}$ ) turf wars as "black on black" violence:

The strife in the townships which reveals a struggle for power between radical and conservative elements may still be filmed ... The impact on the viewers is to support claims that blacks are only prevented from tearing each other to pieces by white law and order. (Davis 1990: 130)

Although speaking in reference to television coverage of South Africa by Western news media, Davis's comments arguably apply to print media, South African and otherwise, insofar as they adhere to Western news values: "Because of its insatiable addiction to violent images ... news lays itself open to manipulation by the South African Bureau of Information" (Davis 1990: 130).

Such portrayal of black opposition had a further impact on black journalists and papers who, labelled as supporters of one black opposition group versus another, would be shunned accordingly (Akhalwaya 1990). Their credibility among the black community in general was at risk:

in the late 70 s and early 80 s senior black journalists thought long and hard about our roles ... whether we should be involved in telling readers only part of the truth ... People in black townships saw what was happening, and sometimes

\footnotetext{
${ }^{30}$ For details on security and police force involvement in fomenting township violence in the early $1990 \mathrm{~s}$, see Republic of South Africa (1998c); see also Wilson (2001) (in particular "Theorizing the Third Force").
} 
reports of incidents bore a distinct dissimilarity to what they had witnessed. (Akhalwaya 1990: 52)

Skewed coverage contributed to a type of censorship from activists: "Some groups have taken it upon themselves to label journalists and the emerging newspapers as being members of one or the other rival ideological group, to be shunned or boycotted if they are not kosher" (Akhalwaya 1990: 55). The Weekly Mail's dilemma over covering abduction allegations against Winnie Mandela is another example of this type of censorship and raises important questions: when, if ever, does the source of the transgression matter and when does it not? What about adding fuel to the fire of the apartheid government's rhetoric or becoming unwittingly involved in a smear campaign? How are "independent" and "critical" defined and at what cost? (Harber 1989, 2004). Press freedom was further hampered by the industry's establishment of a Press Council and its contested and conflicted relationship with the apartheid government. Under constant threat of a statutory press council throughout the 1950s, in 1962 the National Press Union set up the Press Council (known at the time as the Press Board of Reference). According to the Truth Commission media hearings, support for the Board and its code of conduct originated with the Argus group ("Argus Chair Leyton Slater steered the scheme through") and the Afrikaans papers, while SAAN representatives opposed it (Republic of South Africa 1998a: 193). The code did not require protection of sources and journalists were called upon to "take cognisance of the complex racial problems of SA and the general good and safety of the country and its peoples"' (Press Council quoted in Republic of South Africa 1998: 193). Notably, the South African 
Union of Journalists (SAUJ), formed in 1920 for white journalists ${ }^{31}$, was excluded from negotiations between the Nation Press Union and government; the SAUJ eventually recognized the Council in 1971.

The government consistently charged that the Press Council lacked teeth and, through constant threats, "was able to force it to apply self-censorship incrementally over the years" (Republic of South Africa 1998a: 194). In January 1967, the President of the National Press Union concluded an agreement with the Minister of Defence that was supposed to secure regular contact between the union, the South African Defence Force, and the state-owned Armaments Corporation of South Africa. Crucially, the agreement also later provided the basis for the provision of press identity cards (Republic of South Africa 1998a). Some approached the Press Council and its agreements with the view that some news was better than none and that self-regulation was preferable to government regulation; others, however, accused the industry and media bosses with outright collusion. At the very least, the Press Council was unrepresentative in its make-up, comprised as it was solely of white representatives.

In its submission, Independent Newspapers distinguished between where the company failed in human rights, and where the company and its staff were themselves victims of human rights abuses. The ANC submission (1997) looks at the media as employers and as disseminators of information, addressing the state and private broadcast media, and the commercial and independent print media in turn. Both submissions provide anecdotes that attempt to draw a distinction, however blurry, between the acts of

\footnotetext{
${ }^{31}$ Mixed trade unions were outlawed in 1958. The SAUJ tried unsuccessfully to have itself exempted from the legislation. In the 1970s then SAUJ President Clive Emdon began campaigning to de-register the union. This occurred in 1977 after which black members were permitted to join (Republic of South Africa 1998a).
} 
institutions and individuals. According to Jon Hobday, then editor for Saturday Argus and Sunday Argus, management was generally conservative, though there was a clear line between management and editors: "[management] instinct was to be good boys and not to interfere with the business. It was left to editors to cause the trouble" (Independent Newspapers 1997: Section 2 Company Culture). This did not mean that all editors did (cause trouble, that is). Others argue that control was exercised through the hiring and firing of editors. Thami Mazwai, then senior assistant editor of Sowetan (Argus), points to Times Media Limited's (previously SAAN) firing of three prominent English-language editors. They were all fired ostensibly for business reasons, but each of them had been involved in confrontations with the government:

This affects us as journalists in the sense that, if the newspaper owners can fire white editors who step over the line, what chance do you have as a black journalist? You are expendable and they can always get rid of you. (1990: 63) Mazwai's example in turn draws attention to the different experiences and treatment of black and white journalists. The colour bar and other discriminatory and anti-worker legislation were at the disposal of media companies as employers. Black journalists who participated in demonstrations were penalized two days leave or pay, whereas white journalists did not suffer the same penalty; petty apartheid was enforced with segregated toilets and canteens; black journalists were not paid, trained, or promoted as much as their white counter parts; black editors at commercial white-owned black papers had white overseers (Independent Newspapers 1997; Freedom of Expression Institute 12 - 18 September 1997; Republic of South Africa 1998).

The question of complicity with apartheid on the part of the mainstream English press is not easily answered, as demonstrated by the above discussion. It is clear that the 
English press benefitted materially from white exploitation and control of cheap African labour before and during apartheid. English mining magnates owed their prosperity to this system, and they provided the capital that enabled the emergence of a heavily concentrated and powerful English press in its own right. The press further benefitted from apartheid's labour legislation, as just described. What is less clear is the extent to which the English press, in its daily operation and content, could be said to uphold the discriminatory exploitative capitalist status quo; and the extent to which it could be said to challenge the state apparatus enforcing that status quo.

That such exploitation had long been accepted and then institutionalized does bear some consideration: the cognitive distortions of a different climate of beliefs and values should enter into any judgment of the press's culpability, as should the virtual minefield in which apartheid-era journalists attempted to carry out their work (Cooper 2001). This does not mean that one cannot hold the press morally and materially responsible for the overall result. Morally, the Truth Commission made this judgment by taking into account both individual agency and the social, organizational and ideational context that surrounded the agency of individuals and organizations within the industry (Arendt 1965; Cooper 2001; Chinapen and Vernon 2006). Materially, post-apartheid state policy has apportioned/administered responsibility for past transgressions and their correction by obliging white-owned press houses to transform the racial composition of the industry from ownership down to the newsroom.

These measures represent the continued sway of politics over profit imperatives, necessarily so - in South Africa, exercising preference over who will acquire what and who will gain employment where is an integral part of the reforms taken to change the 
structure of ownership and terms of journalistic work that were previously externally and/or arbitrarily controlled. The question, around which present debates about press and democratic reform revolve, is the extent to which these processes of structural transformation remain externally controlled - that is, beyond the reach of popular scrutiny and participation.

This chapter has shown that, historically, the political economy of South Africa, despite all of its obvious repressive and inhumane characteristics, has had an ambivalent effect on the press industry. The effects were ambivalent because despite the obvious and thorough control of resources, political power and decision-making by the white population, the needs of capital and the peculiar qualities of knowledge, journalism and the press, all combined in unintentional ways to leave some margin for manouver and, crucially, critique. On the one hand, the pivotal role of large-scale capital in the South African economy necessitated the increased inclusion of black South Africans, which in turn contributed to a black middle class and strengthened the hand of the re-emerging black labour movement. This widened though still limited inclusion was replicated in the country's media economy, where a (small) space was opened for the articulation of black grievances and aspirations. Moreover, journalistic skills honed in one place (by black journalists working for the dominant white-owned newspaper publishers) could also be used to other ends (in the black, alternative press, theatre, literature, and so forth).

On the other hand, and simultaneously, the dominance of large-scale capital subsumed the earlier independent African press, while also leaving the resulting commercial black press subject to the whims of white-owned press conglomerates battling for dominance of the English-language market. These whims did not answer 
solely to profit imperatives but interacted with various levels of state censorship which, in the context of inclusion and exclusion, were one means of maintaining the truncated position of black citizens with the country's political economy - by denying them a mass and mainstream platform for opposing their exclusion.

In the era of multi-racial democracy, black South Africans are the dominant political actors but they can no more dispense with the needs of capital than their predecessors. While politics in the new South Africa demand a more comprehensive inclusion of black citizens within the post-apartheid political economy, profit imperatives continue to exclude all but a relatively small class of affluent black and white citizens. Once again, this situation is replicated within the country's media economy. Inclusion and exclusion in the post-apartheid public sphere continues to be fundamentally, though not deterministically, tied to pre-existing - and constitutionally-protected - property relations. These dynamics, which link the construction of contemporary South African society to the construction of its media of communication, are the subject of the final two chapters. 


\section{Chapter 4 Limited Democracy, Press Reform and the Post-Apartheid State, $1990-2005$}

In considering class struggle in the post-apartheid era Cronin writes that " $[\mathrm{t}]$ he struggle of memory against forgetfulness about the role of popular power in the negotiated transition is itself an important, contemporary democratic struggle" (2005: 4). He is referring to the perception, based in theories of "limited democracy" espoused by those such as Samuel Huntington (1991) that South Africa's transition was a product of elite choice, beliefs and action. Characterizing the transition as elite moreover suggests that the subsequent consolidation of South African democracy depends on pact-making and consensus among elites.

This chapter considers these perceptions in order to illuminate how the limits placed upon institutional change have in turn impacted the transformation of the press industry. It pays particular attention to how processes of inclusion and exclusion function in the post-apartheid political economy, with particular reference to corporatism and black economic empowerment. The second part of the chapter will look at these processes in the context of the changes in press ownership that occurred beginning in the 1990s, while the following chapter will demonstrate how these dynamics play out within the newsroom, in terms of the politics of journalism and current debates about press reform.

\section{Post-Apartheid South Africa and the Limits of Democracy}

In chapter one I introduced the technocratic elitist model of democracy to account for the prominence of elites and state bureaucratization in contemporary democracies, and the 
consequent focus on institutional change as the bedrock feature to be installed as securely in new democracies. This model is premised on the belief that living in a modern industrial society imposes limits on participatory democracy, thereby leaving the state primarily to promote the competition of values, the rule of law and administrative expertise, and the freedom of choice come election time (Held 1996). Class factors into this model of democracy not in exploitative terms but as representing "aggregates of individuals who share similar sets of 'life chances' in labour and commodity markets" (Held 1996: 160). Class conflict is thus not unimportant but neither is it a key defining characteristic in the distribution of and struggle for power. Pluralism takes its cue from this view of power, arguing that almost every group has some kind of advantage that it can use to affect the democratic process (Held 1996: 202). Subsequently, majorities do not "rule" in the sense of coordinated action, but "govern" via the consensus of values arising from their very participation (Dahl 1956: 132 in Held 1996: 207).

In South Africa, the focus on institutional change and the pragmatics of group politics have been fundamentally shaped by historically given and constitutionallyprotected property relations. Consequently, the historical context of popular, collective self-empowerment has been overwhelmed and displaced by a technocratic and capitalistoriented outlook that hegemonizes representative structures and the interpretation of rights (Cronin 2005). This is demonstrated in the disconnect between the participatory local forums that were so instrumental to the struggle against apartheid, and the formal mechanisms that have become a feature of post-apartheid democracy. Corporatism which is itself an institutionalized form of elite bargaining - has become a central feature of the country's institutional architecture; it extends formal representation to all citizens, 
but does so by seeing them primarily as members of organized business, labour, and civil society groups. Such corporatist structures of representation come at the expense of participation: it formalizes the inclusion of these groups in the formulation of state policy, but excludes the un-organized or those who do not fit within these categories.

The disconnect was foreshadowed by the constitutional negotiations carried out early in the transition from apartheid to the post-apartheid era. While the participatory forums of the struggle wielded historical leverage that necessitated their inclusion in the negotiations, not everything was on the bargaining table for all groups to participate in. Political and economic negotiations proceeded along parallel and often intersecting tracks, but the latter had a far lower profile and bargaining was mostly confined to elites of the ANC and the National Party (Horwitz 2004; Klein 2007). The apparent two-fold strategy of the outgoing National Party was first, and in explicit reference to the Washington Consensus, to portray key areas of economic decision-making as "technical" or "administrative"; and second, to use new policy tools such as trade agreements and structural adjustment programs to transfer control of the economy and state finance to experts and economists both within the National Party and the ANC, as well as from the International Monetary Fund, the World Bank, and the General Agreement on Tariffs and Trade (Klein 2007: 240). With the formation of the Government of National Unity ${ }^{32}$, the ministries of Finance and of Mineral and Energy Affairs were allocated to the National

\footnotetext{
${ }^{32}$ The GNU as it became known, was originally supposed to last until 1999. The Interim Constitution stipulated that every party that captured 20 percent of the seats in the National Assembly would be entitled to designate an Executive Deputy President (from among the elected members); if no party met this condition then the parties with the largest and second largest number of seats would be entitled to each designate an Executive Deputy President. Parties meeting the 20 percent would also be eligible to hold one or more portfolios in the Cabinet, Ministers appointed this way being capped at 27 (Republic of South Africa 1993a). In the event, FW de Klerk (National Party) and Thabo Mbeki (ANC) became Deputy Presidents, while the National Party and the Inkatha Freedom Party had seats in the Cabinet. The National Party left the GNU in 1996 to join the opposition, while Inkatha stayed on in a coalition government until 2004.
} 
Party (Michie and Padayachee 1997). Property rights and the independence of the central bank were secured as were the tenure and pensions of existing civil servants. Klein writes: “"The people shall govern!' would soon become a reality, but the sphere over which they would govern was shrinking fast" (2007: 240). Taking place at the beginning of the 1990s, negotiations corresponded with an outbreak of violence so severe and seemingly random that the country was said to be on the brink of civil war. Investigative journalist William Gumede recalls: "Everyone was watching the political negotiations ... if people felt it wasn't going well there would be mass protests. But when the economic negotiators would report back, people thought it was technical" (as cited in Klein 2007: 247). With the passage of the Interim Constitution (1993), property rights, the civil service, the central bank, and the acceptance of some kind of amnesty in post-apartheid South Africa were closed to further discussion.

In terms of areas that have become open to wider participation, the working assumption seems to be that entire communities can be represented by a single organization (Friedman 2006: 2). At the same time, government and policy-makers must deal with continued white control of capital, skills and elements of the civil service. As a result, formal participatory mechanisms are hemmed in by the deference given to those well able to organize as well as to legacy interests ensconced in the civil service and key sectors of the economy and state finance. As Steven Friedman puts it, "[t]he intent is not to broaden and deepen democracy but to ensure smoother government" (2006: 4).

Generally speaking, participatory governance can represent an instrumental desire, such as a means of binding organized constituencies to agreed policy outcomes (corporatism); or it can embody a normative goal to give voice to the voiceless (Friedman 
2006). It appears that it is the former that has taken root in post-apartheid South Africa, where corporatism stands in as a poor substitute for attitudes and institutions amenable to citizen action (Friedman 2006: 3). This is not to say that corporatism has not worked; the point is that it should be judged for what it is and on its own merits rather than seen in overly idealistic terms as an "inclusive" democracy. Rather than a robust and participatory kind of democracy, what has taken shape is a form of regulated and institutionalised bargaining between labour, business and the state at the expense of greater participation (Adam et al 1997: 140). In more formal terms, the system that has been put into place is limited to "singular, compulsory, hierarchically ordered and functionally differentiated categories, recognized or licensed (if not created) by the state and granted a deliberate representational monopoly" (Schmitter 1974: 93-4). In short, this is "limited democracy" and the ramifications of that reality are far-reaching indeed, not least for the kinds of press and media reforms that have been put into place.

By all accounts, corporatism has succeeded in bringing about a particular kind of democracy - one that provides a bridge between the late-apartheid and post-apartheid economy but which breaks with the popular participatory tradition it was supposedly meant to formalise. Focusing on the entrenchment of corporatist relations, and on what he terms South Africa's “elite transition”, Patrick Bond offers an incisive critique of the results: "what was of greatest curiosity to the casual observer was the evolution of the scenario plan from corporate survival strategy to social contract parable, for here noxious social myths could be more readily born and bred" (2005: 41).

Corporatism, along with the constitutionally-protected economic "safeguards" that resulted from the negotiations, has had profound consequences for the other 
painstaking work of transition and for the key democratic institutions that have been created as a result. The Truth and Reconciliation Commission is one such example where the import of the "public history lesson" may well have been overshadowed by what was communicated by omission: the commission's "narrow, individualistic, and legalistic orientation ... meant that apartheid's victims were only those thousands who were physically abused, rather than the millions who suffered economically as a result of the day-to-day workings of the exploitative system" (Mahmood Mamdani 1996 as cited in Horwitz 2004: 117).

Thus the Truth Commission assigned moral but not material responsibility; here it was limited to suggestions. In March 2003 commission chairman Archbishop Desmond Tutu presented the final report to then-President Thabo Mbeki. Already, even Tutu was fully aware of the limits of the process that he had just overseen and lent his considerable moral authority to. In light of the "disappointing" response from business regarding reparations, the final report reiterated the commission's recommendations that had been first proposed in 1998 , in a report to then-President Mandela. ${ }^{33}$ The report also called on the government to reconsider its responsibility for repaying the debt incurred by the apartheid government in maintaining their repressive state apparatus. In the first years of the new democracy this debt cost the government 30 billion rand (just over $\$ 4$ billion) annually, to the detriment of reparations, reconstruction and development (Klein 2007: 254). The government rejected the commission's advice. Instead, it provided, from its

\footnotetext{
${ }^{33}$ The commission asked the government to consider: a wealth tax; a once-off levy on corporate and private income; a once-off one percent donation from each company listed on the Johannesburg Stock Exchange from its market capitalisation; a retrospective surcharge on corporate profits extending back to a date to be suggested; a surcharge on golden handshakes given to senior public servants since 1990; looking into the SA Special Risks Association Fund, contributed to by business and individuals as insurance against material loss arising from political conflict (Republic of South Africa 2003b).
} 
own constrained budget, a fraction of what had been requested, and even went so far as to condemn cases then underway in U.S. courts against international businesses and lending institutions that had profited under apartheid (Valji 2003).

As Tutu stated with the release of the final report

Can you explain how a black person wakes up in a squalid ghetto today, almost 10 years after freedom? Then he goes to work in town, which is still largely

- white, in palatial homes. And at the end of the day, he goes back home to squalor? I don't know why those people don't just say, 'To hell with peace. To hell with Tutu and the truth commission'. (as cited in Klein 2007: 254)

Economic justice is as yet forthcoming and this taints what justice the commission did manage to achieve.

In regards to more traditional institutions for conflict management, however, such as parliament, the constitution, and the judiciary, it is important to note that in South Africa, these institutions were negotiated and developed alongside not prior to corporatist relations. For example, the National Economic Development and Labour Council, formed to "consider all significant changes to social and economic policy before it is implemented or introduced in Parliament" was established in 1994 (Republic of South Africa Act No. 35 Section 5.10). It aims to bring together organized labour, organized business, and organized community groupings for social dialogue (Nedlac 2008) ${ }^{34}$. At the top of the hierarchy is the Executive Council, consisting of Ministers and senior officials of Government; General Secretaries and senior office bearers of labour; captains of industry and senior officials of employer organisations; and senior representatives of

\footnotetext{
${ }^{34}$ Organised business is represented by the newly formed Business Unity South Africa (BUSA), which brings together the Black Business Council (BBC), and Business South Africa (BSA); organised labour is represented by the three main labour federations in South Africa: Cosatu, Fedusa and Nactu; organised community is represented by the South African Youth Council, National Women's Coalition, South African National Civics Organisation, Disabled People South Africa, Financial Sector Coalition and the National Co-operatives Association of South Africa
} 
the Nedlac Community Constituency. The Executive Council meets quarterly to discuss "key strategic issues facing South Africa's economy" (Nedlac 2008).

Having this particular kind of (corporatist) participatory mechanism running parallel to institutions traditionally charged with channelling conflict, such as parliament, is deeply problematic. For one, it bypasses, and thus erodes respect for parliament. In so doing, it substitutes the consensus of functionally organized "expert groups" for the will of the people, as represented in and through Parliament. In short, the process takes place outside direct electoral accountability (Held 1996). Corporatist arrangements that are not only parallel but prior to a newly established parliament render the latter toothless before it can even begin. In South Africa this process is compounded by the ANC's consistently large electoral majorities - it won 69.7 percent of the votes in 2004 and just under 66 percent in 2009 - and the politics of the party-list system (Electoral Institute of Southern Africa $2007 ; 2009) .{ }^{35}$ Citizens must therefore contend with the hierarchy of either the liberation-movement-turned-political party or of organized interest group politics, where those with the most resources to organize have the most influence.

What then does empowerment mean in the new South Africa? It appears to be the idea

that power is, somehow, a capacity which can be transferred from those who have it to those who do not by a technical process ... that the 'poor and marginalized' can attain power only if the technicians find the appropriate 'participatory process to grant it. (Friedman 2006: 9)

\footnotetext{
${ }^{35}$ Seats in South Africa's National Assembly (Parliament) are allocated according to a proportional representation party-list system. Voters cast their ballot for a party and seats are then assigned following a list of individuals that the party has drawn up, starting with the person topping the list and continuing on until the party's proportion of seats are filled. Within the ANC, the process of compiling the party list is quite participatory, at least in the preliminary stages, where candidates' names are forwarded from the local branch level. However, things become considerably less democratic when it comes to who will be included on the final list and at what position, both of which are decided by party leadership alone. See Feinstein (2009).
} 
It is power transferred from those who have it to those who do not at the convenience of the former - in this case, the elites, both white and black, old and new.

One embodiment of this logic in post-apartheid South Africa appears to be the policy of Black Economic Empowerment (BEE) - a key vehicle obstensibly designed to drive the transformation of the country's economy. BEE has been widely understood and criticized - as the government's affirmative action program. More than just being a vehicle to promote employment and ownership equity, however, the BEE initiative has aimed to achieve "meaningful participation in the economy by black people in order to achieve sustainable development and general prosperity" (Republic of South Africa 2006b: 3). ${ }^{36}$ As a strategy, BEE is presented as simultaneously a matter of redress and a means of sustainable growth (Republic of South Africa 2006b). As an unspoken principle in the early stages of transformation among the business sector, it came to be associated with changing the face, literally, of management and ownership. However, by transforming the racial base of capital while leaving its logic untouched, BEE was bound to disappoint. Subsequently, and more notoriously, it has become associated with the enrichment of an elite class of black businessmen amidst a general continuance of the apartheid status quo.

BEE has brought about modest though steady and significant growth in the provision of basic services as a form of "capabilities" empowerment - providing people with things such as running water and electricity that will hopefully enable them to

\footnotetext{
36 "Black" being defined as "a generic term which means Africans, Coloureds and Indians", immediately followed by the definition for "broad-based economic empowerment" as "the economic empowerment of all black people including women, workers, youth, people with disabilities and people living in rural areas" (Republic of South Africa 2006b: 2). In June 2008 the High Court ruled that South-African-born Chinese (pre-1994) also qualified as "black" - a determination that caused quite a stir in some circles; see Chang (2008).
} 
participate and benefit more fully from economic empowerment (Horwitz 2001: 351). ${ }^{37}$

This has been facilitated by parastatal policy initiatives since 1994 that allowed for limited privatization and liberalization in the provision of these services. Through black economic empowerment, unions have set up investment arms which in turn have been used to fund bursaries for workers' children, training for retrenched workers, and to provide mortgages to members at reduced rates (Horwitz 2001: 352-3). The question is whether such activities contribute to the development of capital outside the control and influence of established large-scale capital (Horwitz 2001: 353).

Indeed, if the development of independent black capital and a black capitalist class is supposed to be one of the goals, the reality is that much of the emerging black capital is comprador in nature. That is, it relies on the patronage of well-established capital. This capital can also be described as parasitic, given its close association with the ruling party. Given how the policy has unfolded, Bond concludes that "if ever there was a case that white South African elites laid a neoliberal ambush for their successors, BEE is it" (2005: 28). Bond describes why it is more a case of "black economic disempowerment": the strategy met with depression in the 1990s, then fragile growth and overtraded markets; excessive trade liberalisation; monopolised industries; the government's "frightened withering from market interventions"; the highest stock price/earnings ratio ever, and the highest real rate of interest (Bond 2004: 33). ${ }^{38}$ These

\footnotetext{
${ }^{37}$ The reach of such provision is by no means comprehensive and service delivery remains a central issue in many communities. Lack of delivery has led to demonstrations, some of which have escalated into violent confrontations with local authorities, such as occurred in Sakhile, Palm Ridge, and Ntabazwe in October 2009.

${ }^{38}$ For a more detailed account of the average experience with petty capitalism in the townships and rural areas, as well as significant and suspect deals and bankruptcies among high-profile black businesses, see Bond (2004): 28-33; for a discussion and case study of how petty capitalism within the so-called "second ['informal'] economy" might actually be generating organic capital and extending production while fulfilling real social need, see Cronin (2005): 14-18.
} 
are the signature features of a hobbled state and, as Noami Klein (2007) might put it, disaster capitalism - all at the expense of the much hoped for transition to democracy.

Within this context, we must also ask if freedom itself has become commodified in the new South Africa? The answer is yes, to the extent that capital accumulation and conspicuous consumption among a growing black middle class have come to represent a benchmark of empowerment. This is not unique to South Africa, but mirrors processes that are nearly complete in other capitalist democracies. The domestic dynamics of South Africa are also caught up in the globalization of the kinds of politics that produce such outcomes. One can consider the anti-corporate backlash and anti-globalization protests of the late 1990s as cultural indicators of the disconnect between democracy as a beacon of freedom and its demonstrated material realities, where those with the most money have the most influence. In South Africa in the 2004/05 financial year alone there were 6000 recorded protests (Delaney 2007). The recognition of institutionalized exclusion has led to new kinds of social movements, in South Africa and elsewhere, that reject the premise that the state will provide the opportunity for substantive citizenship (Khan and Pieterse 2004: 2). In this way, continued exclusions within the South African political economy have once again given rise to responses outside the sphere of formalized politics.

\section{Remaking the Press for Limited Democracy}

The previous section discussed how democratic centralist tendencies and corporatism have fixed attention on government policy and institutions as the loci of change. That 
state-led change and institutions likewise dominate press coverage is partly due to these processes. It is also a function of liberal news values and the watchdog role attributed to the press. What impact has this interaction had on transformation, perceived and actual, of the South African press industry?

The focus on black economic empowerment has centered on transforming the material base of the media industries, from ownership down to newsroom management and staff composition. The remainder of this chapter describes the ownership changes that have taken place. It demonstrates that although significant transformation has occurred, ownership of the mainstream press remains concentrated and has become more fully geared towards profit-maximization. This shift has produced ambivalent outcomes in the broader sweep of transformation in which black South Africans are increasingly, though not equally, incorporated into the country's political economy, as citizens, readers and consumers. The final chapter discusses how these outcomes are fuelling current debates about press reform and why - namely because transformation has aimed to change the look but not the logic of capital.

Murdock's (1982) distinction between "legal" and "economic" ownership helps us to make sense of and assess the changes that have occurred in the media industries during the 1990s. Legal ownership refers to general shareholding, while economic ownership indicates possession of voting shares that can be used to achieve effective representation on a corporation's board of directors. The main benefit of legal ownership is the return one receives in dividends. Economic ownership, however, entails the ability, and the responsibility, to steer the company by allocating resources and setting long-term planning and policies. In terms of black economic empowerment, opening up general 
shareholding through discounted shares in previously white-held companies has allowed black South Africans, whether as individuals or as groups, to literally reap the benefits of fuller participation in the country's economy. It is a means of including them in the country's economy not just as labour, but as (small-scale) investors. Historically, this means of encouraging financial advancement parallels the way small-scale Afrikaner capital was mobilized at the turn of the century to make inroads into an economy that was dominated by large-scale English capital. Indeed, some of the companies that backed the rise of Afrikaner power, such as the South African Life Insurance Company (SANLAM), did the same for black business in the post-apartheid era (McGregor 1996b). Bringing black South Africans onto boards of directors further extends this inclusion to participation in setting the corporate agenda.

Murdock also distinguishes between different levels of control: "allocative" control is the power to define the overall goals and scope of a company and determine the way it deploys productive resources; "operational" control is confined to decisions about the effective use of resources that have already been allocated and to implement policies already decided at the allocative level (1982: 122). This is where the distinction between economic and legal ownership is important, because it is only the former that confers allocative control. Beyond the allocative level, day-to-day decisions are taken at the operational level, where the more specialised knowledge and expertise of, for example, editors and journalists operating in a newsroom, is of decisive importance. This, of course, means that they have some potential to influence the kind of stories that get produced, and those that do not. 
There is one more piece to this puzzle: the "managerial revolution" thesis. The "managerial revolution thesis" argues that dispersed shareholding and the separation of ownership from management has created "a fundamental shift in the locus of corporate control". With ownership largely dispersed among thousands, even millions, of shareholders, "only the full-time executives are in a position to keep track of developments ... and can present the available options [to the board] in ways that favour the policies they would like to see implemented" (Murdock 1982: 132). To the big question about who rules and in which class interests the modern corporation is controlled, the managerial revolution thesis answers that the managerial class is now in control (Murdock 1982).

In many ways, debates about press transformation in South Africa turn on this point and how the dynamics of modern media corporations play out across the two levels of control: allocative and operational. At the allocative level, questions arise as to the extent to which control has really been transferred in the post-apartheid era and the conditions under which this transfer occurred. For example, the first phase of ownership changes in the English press took place in 1993 when Argus sold 52 percent of the blacktargeted Sowetan, then South Africa's largest daily newspaper, to Corporate Africa, a black-owned consortium that had the financial backing of SANLAM (Tomaselli 2002). Corporate Africa, in turn, is the holding company for New Africa Investments Limited, the leading black-owned investment company at the time. Argus retained a 42 percent share in the paper, along with printing, advertising and management contracts. In contrast to the fragmented interests arrayed within this consortium, Argus constituted a more coherent "ownership bloc" and thus maintained significant allocative and operational control - at least until 1997 when its remaining shares were bought by New 
Africa Investments. Eventually then, the sale of the Sowetan did entail full divestiture from white control, albeit over a substantial period of transition (Tomaselli 2002).

In 1990, Argus Newspapers, including the Sowetan, accounted for over 50 percent of daily newspaper sales in the country (National Press Club 2009). As just indicated, once Apartheid crumbled, the Sowetan was sold and eventually became a part of the newly constituted Avusa in 2004. However, not long after this transaction, and indeed, before the general election that swept the ANC to power in April 1994, another crucial change in the ownership of the South African press took place. Irish-based Independent Newspapers Plc, a division of Tony O'Reilley's H.J. Heinz, acquired a 31 percent stake in Argus. In the same month as the elections, Argus, now 31-percent-owned by Independent Newspapers, purchased Times Media's interests in the Cape Times, the Natal Mercury, the Daily News, and the Pretoria News. This gave Argus, and through it Independent Newspapers, dominance of the Cape Town and Durban English-language press markets, and market leadership in Gauteng ${ }^{39}$ (Fourie 2004). O'Reilly increased his share to 58 percent the following year.

The ANC endorsed these arrangements on the understanding that Independent Newspapers would expand black participation at shareholder and directors levels. This, however, did not happen. In April 1999 O'Reilly bought out the remaining shareholders (24 percent) and de-listed the company in South Africa to become a private company with close to 100 percent of the shareholding held by Independent News and Media PLC (Berger 2001; Horwitz 2001; Fourie 2004). In essence, O'Reilly had put one of the

\footnotetext{
${ }^{39}$ Gauteng is the smallest but most densely populated province; just over 20 percent of South Africa's population live here. It is the country's economic and political hub and includes Johannesburg (home to the Constitutional Court), and Pretoria, the de facto capital city where the executive branch of government sits.
} 
country's most significant press groups - accounting for about $18 \%$ pecent of the national newspaper market in 2008 - beyond the reach of the ANC and domestic capital.

Allocative control is geared towards capital accumulation, but in this case for large-scale foreign-held capital and without little overture to black empowerment, whether that is seen in terms of black capital, black journalists or black citizens. The result, as the latest annual report of the Independent News and Media Plc notes, has been the ability of the papers to focus aggressively on advertising, "selective cover price increases and an unrelenting focus on operating cost reduction and business process improvement initiatives" (Independent News and Media PLC 2008: 11). In 2008 alone, the company reported a $€ 138$ million reduction in operating costs and a head count reduced by over 630 over the course of the year, with another staff reduction of 160 to take place in the early part of this year. This is a questionable way to build a rigorous press befitting a democracy, whether in South Africa or anywhere else for that matter.

The third phase of changes, in which the country's second largest English press group came under black ownership, represented the largest cash deal in South African history (Tomaselli 2002). However, the transfer of allocative control in this case was not as clear-cut. Anglo American had effectively controlled this press group, Times Media Limited (formerly SAAN), since the $1980 \mathrm{~s}$ - as outlined in chapter $3{ }^{40}$ Legislative changes in the 1990s enabled Anglo to split JCI into three separate divisions: platinum, mining, and industrial. The last of these was known as Johnnies Industrial Corporation, or "Johnnic", and was comprised of Times Media along with a diverse range of interests, including SA Breweries, clothing, furniture and hotel interests, and a music, film and entertainment company (Financial Mail 2000).

${ }^{40}$ Through its subsidiary, Johannesburg Consolidated Investments (JCI). 
New Africa Investments had the management experience and financial backing to purchase Johnnic on its own. But in 1994 New Africa had joined a loose association of businesses and unions called the National Empowerment Consortium. At the time, its holding company, Corporate Africa, consisted of four controlling interests, one of whom was a white businessman. Corporate Africa's pyramid organization also meant that three of its principals could control New Africa with only 10.8 percent ownership (McGregor 1996b in Horwitz 2000: 311). Given these factors, other members of the Consortium, and Anglo American, questioned New Africa's commitment to black empowerment (Tomaselli 2002). In the end, the National Empowerment Consortium acquired the dominant interest (41\%), including voting rights, in Johnnic, in 1996 (Tomaselli 2002). Anglo American retained 6.4 percent of its original shares. Nonetheless, the National Empowerment Consortium was clearly in control, with its dominant economic ownership backstopped by the legal authority to appoint the chair as well as half of the 20 seats on the board of directors at the newly-constituted Johnnic.

The deal was hugely symbolic. It pushed black control of the Johannesburg Stock Exchange to nearly 10 percent in just over two years of ANC rule (McGregor 1996b; Tomaselli 2002). In comparison, after the National Party came to power in 1948, it took Afrikaner capital twenty-six years to reach 7 percent market capitalization on the JSE, and it did not reach 25 percent until the mid-1990s (Tomaselli 2002). However, the deal needs to be seen as having taken place in the context of over-heated markets and trade liberalization (Bond 2004). As a result, the National Empowerment Consortium, and other black businesses now possessed hyper-inflated shares acquired at high interest rates in a relatively stagnant economy (Bond 1997 in Tomaselli 2002). In addition, the lending 
institutions that financed the purchase demanded 13 to 20 percent returns, with some members forfeiting all but their voting rights in Johnnic to get the necessary funding (Sunday Times/Business Times 1996). Competition between Consortium members for loans from the same institution exacerbated the situation, with some members agreeing to repay loans within three to five years (Financial Mail 2000). Most unions acquired ownership (with voting rights) using pension and provident funds (Sunday Times/Business Times 1996; Tomaselli 2002).

The result of these conditions and constraints was that Johnnic, now black-owned, was immediately and largely concerned with increasing its net value. Allocative control was geared towards capital accumulation, not just for its new black shareholders, but for well-established, dominant white capital. Further complicating matters, as a diversified holding company Johnnic management were limited to attending various company board meetings and managing dividend inflows (Financial Mail 2000). Management, supported by board chairman Cyril Ramaphosa and by Anglo, decided to restructure the company (Financial Mail 2000). The restructuring began in 1997 when Johnnic sold 50 percent of its business publishing interests, including the daily newspaper Business Day, to the UK group Pearson Plc, forming BDFM (Business Day Financial Mail) as a joint venture between the two groups (Financial Mail 2009). Plans to swap Caxton and SA Breweries shares for additional MTN (Mobile Telephone Networks) fell through and Johnnic decided to borrow R4 billion to buy the additional MTN shares as well as to buy out minority shareholders in Times Media and Millennium Entertainment Group (Financial Mail 2000). 
In 1998 share prices dropped from R70 in April to R21 per share at the close of that year, rising only to R35 by the middle of 1999 (Bond 2004: 32). ${ }^{41}$ By December, pressure to repay the debt accelerated plans to sell off assets and to leverage synergies between core businesses. Within the first few months of 1999 almost R 3billion of the loan had been paid, and by August 1999 it was down to under R 1billion. Thus, at the turn of the millennium, rather than focusing on creating a better press befitting the new democratic dispensation of post-Apartheid South Africa, attention was focused on repaying debt, meeting investor demands for high returns and establishing a foundation for long-term corporate growth. The overall result at the end of this stage of the process in 2000 was an enormous multimedia entity named Johnnic Communications, or "Johncom". The trend was reinforced in 2004 when Johnnic acquired the Sowetan and Sunday World ${ }^{42}$ from New Africa Investments (Milne and Taylor 2006). In 2007, Johnnic was rechristened Avusa Limited. The entity now possesses a vast stable of media assets that span print, digital, and entertainment media, book and map publishing, and retail outlets.

If pluralism and diversity were to be one of the objectives of the new South Africa, the continued concentration of the media industry leaves much to be desired. Seen through a somewhat larger lens, Anglo American's sale of Johannesburg Consolidated followed worldwide trends: its press interests were not only furthest removed from its core mining business, but were also the investments with the most "nuisance value" (McGregor 1994: 12). While the newspapers were profitable in their virtual dominance of the English-language market, their revenue was small relative to the

\footnotetext{
${ }^{41}$ Or from 10 CAD to 3 CAD then back to 5 CAD.

${ }^{42}$ Launched in 1999.
} 
conglomerate's billion-dollar international mining operations (Tomselli 2003). As such, they were not worth the political attention they attracted as sources of cultural power.

The Afrikaans press also underwent substantial transformation within the first few years of post-apartheid South Africa. Naspers was first listed on the Johannesburg Stock Exchange in 1994 (McGregor 1996a). Change was geared at the operational level. For example, in 1996 and 1997 Naspers formed new firms and sold shares to companies owned by black business. As part of this process, a controlling interest in City Press, purchased from SAAN in 1984, was sold to black investment groups Ukhozi Media and Dynamo, with the goal of recapitalizing the paper so that it had the capacity to reach one millions paying readers (Tomaselli 2002). In 1999 the company launched The Welkom Share Scheme, through which it enabled more than 17000 previously disadvantaged people to become shareholders (Berger 2000). The bulk of shares however are held by nominee companies that do not reveal the ultimate identity of the owner: 18 percent by Standard Bank Nominees Ltd., 16.4 percent by CMB Nominees Ltd., and 15.2 percent by Nedcor Bank Nominees Ltd. as of 2000 (Fourie 2004). In 2000 Naspers was reorganized into a holding company with five subsidiaries; the wholly-owned Media24 comprises its information and entertainment assets. A highly pyramided and complicated structure ensures that directors effectively retain allocative control over the company (McGregor 1996a).

Perskor, the other main Afrikaans press group, owned three major newspapers as of 1991: Die Vaderland and Transvaler (both Afrikaans-language), and the Englishlanguage Citizen, the paper that had been at the centre of the Information Scandal in the late 1970s. It also owned Imvo Zabantsundu, which it had acquired from Argus in 1960, 
and had joint-ownership with Naspers of the weekly Rapport. In the early 1980s Naspers bought control of the more conservative north-based Perskor in an attempt to stifle opposition amongst Afrikaners against reforms, such as the 1983 Tricameral Parliament, which the government was attempting to introduce (Muller 1987; Tomaselli 2002). Thus in 1996 Perskor had three controlling shareholders: tobacco and liquor giant Rembrandt (27.1 percent), Naspers (24 percent) and Dagbreek Trust, whose shares will always outvote the ordinary shares according to the company's articles of association (McGregor 1996a). As Naspers was reorganizing to become the continent's leading publishing group, Perskor was on the decline. In 1996 Perskor forged an alliance with the new black-controlled Kagiso Media, an investment of the non-governmental development finance organization Kagiso Trust. ${ }^{43}$ Perskor left the arrangement in 1998. By then it had closed Die Vaderland, Transvaler, and Imvo, and had relinquished its joint ownership of Rapport, leaving it with only the Citizen. Perskor then merged with Caxton/CTP ${ }^{44}$, a printer and publisher of community free-sheets and magazines. As of 2001 Caxton/CTP was 38 percent owned by Johnnic (National Press Club 2009). In 2007 Johnnic (now Avusa Ltd.) listed its Caxton stake separately on the JSE as ElementOne (Avusa 2009). In light of all these changes, by 2000 South Africa's newspaper market was dominated by four reformulated groups: Independent News and Media South Africa

\footnotetext{
${ }^{43}$ The Kagiso Trust was established in 1985 as a result of the European Special Programme for the Victims of Apartheid. It was originally designed as a conduit that would bypass the apartheid government to provide development assistance from Europe to South Africans; in 1990 it became a fully-fledged development agency involved in mobilizing resources and piloting projects. Kagiso Media has interests in broadcasting, information services (LexisNexis), outdoor advertising, and in the staging of exhibitions and events. See Kagiso Media (2009) and Schutte (1997).

${ }^{44}$ Caxton was begun as a small stationery and general printing factor in 1902 . It was without a Web press until 1970, after which it began producing community free-sheets. In 1979 Caxton concluded an agreement with the Argus Group through which it acquired a modern production plant. According to Berger (2000), there was also a legal agreement prohibiting Caxton from entering into the commercial newspaper business, with Argus refraining from competition in the free-sheet and magazine market. In 1995 Caxton broke its ties with Argus and began a partnership with the National Empowerment Consortium.
} 
(formerly Argus), Johnnic/Avusa (formerly SAAN/Times Media Limited), Media24 (Naspers), and Caxton/CTP (including Perskor). The number of groups rises to five if one takes into account New Africa Investments, which jointly owned the Sowetan and Sunday World with Times Media, among other media interests, and which is separately listed on the JSE. Looking at circulation figures in 1994/95, as changes were underway, Independent News and Media dominated both circulation and total sales (Fourie 2004: 146):

Table 4.1: Market Share of Circulation by Group 1994/95

\begin{tabular}{|l|c|c|}
\hline & \% Circulation & \% Total Sales \\
\hline Independent News \& Media SA & 36.5 & 40.8 \\
\hline $\begin{array}{l}\text { Naspers } \\
\text { including 50\% in Rapport }\end{array}$ & 19.6 & 16.2 \\
\hline $\begin{array}{l}\text { Perskor } \\
\text { including 50\% in Rapport }\end{array}$ & 11.8 & 4.0 \\
\hline $\begin{array}{l}\text { New African Investments Ltd. } \\
\text { 50\% Sowetan and Sunday World }\end{array}$ & 11.0 & 5.5 \\
\hline Times Media Ltd. & 10.9 & 21.0 \\
\hline independent publishers & 5.2 & not available \\
\hline $\begin{array}{l}\text { joint publishers of } \text { Ilanga } \\
\text { Mandla Matla) }\end{array}$ & 2.8 & not available \\
\hline
\end{tabular}

Source: Fourie (2004)

As already discussed, between 1995 and 2000 media interests were reconstituted and, eventually, reconsolidated ${ }^{46}$. In 1995 Times Media bought out the formerly independent Daily Dispatch which held a monopoly in its market of East London, Eastern Cape Province. Perskor sold its shares in the national Rapport to Naspers and merged with Caxton/CTP in 1998. In 2000 Naspers acquired a 50 percent stake in the formerly

${ }^{45}$ Formerly Ilanga Lase Natal, founded in 1903 by John Dube.

${ }^{46}$ See Appendix 2 for changes in title distribution across groups between 1990 and 2008. 
independent Witness Printing and Publishing Company, and through it joint ownership of the daily Witness, published in Kwa-Zulu Natal province. The following year Ilanga, a prominent Zulu-language bi-weekly, also in Kwa-Zulu Natal, ended its publishing and distribution contract with Independent and began one with Witness Printing. Media24 eventually took over management of Ilanga in 2007 via its stake in Witness. In 2004 Johnnic acquired New African Investments' media assets, including the Sowetan and Sunday World. By the end of 2008 circulation figures were as follows:

Table 4.2: Market Share of Circulation by Group 2008

\begin{tabular}{|l|c|c|c|}
\hline & $\begin{array}{c}\text { \% Total } \\
\text { Circulation } \\
\mathbf{( 4 2 9 8 ~ 5 3 2 )}\end{array}$ & $\begin{array}{c}\text { \% Daily } \\
\text { Circulation } \\
\mathbf{( 1 6 2 9 ~ 8 2 4 )}\end{array}$ & $\begin{array}{c}\text { \% Weekly } \\
\text { Circulation } \\
\mathbf{( 2 6 6 8 ~ 7 0 8 )}\end{array}$ \\
\hline Media24 (Naspers) & 47 & 52 & 44 \\
\hline Independent News \& Media (SA) & 25 & 29 & 23 \\
\hline Avusa (formerly Johncom) & 22 & 13 & 28 \\
\hline Caxton/CTP & 0.02 & 0.04 & 0.01 \\
\hline
\end{tabular}

Source: Audit Bureau of Circulations South Africa

Apart from further consolidation, the most notable change is that Naspers, through its subsidiary Media24, has surpassed Independent News and Media as market leader. Naspers not only has a monopoly of the Afrikaans market, but it has also gained a sizeable chunk of the English-language market through the Daily Sun tabloid. Introduced in 2002 with a circulation of 71 742, the Sun has grown steadily, posting circulation figures six and seven times as high in 2006 and 2008 respectively (Media Club South Africa 2009; Bauer $2009^{47}$ ). At the end of 2008 the tabloid's reach was estimated at 16.4

\footnotetext{
${ }^{47}$ Ultimately sourced from the Audit Bureau of Circulations South Africa, whose data portal is restricted to members.
} 
percent of South Africa's adult population; its growth has placed it well ahead of all other existing dailies (All Media Products Survey 2008a). ${ }^{48}$

The Sun's success has spurred a growth in tabloids, with Media24 introducing Kaapse Son, the first Afrikaans tabloid, in 2003. Its primary audience is the large Afrikaans-speaking black population in the Western Cape (formerly categorized as "Coloured"). Originally introduced as a weekly, it was changed to a daily in 2005 , with weekly editions introduced in three additional regions. In 2005 Independent attempted to gain a share of this market with the introduction of the Daily Voice, which is published in English "with plenty of Afrikaans slang thrown in" (Media Club South Africa 2009). Notably, Independent introduced a Zulu-language daily in 2002, the same year as the Daily Sun's debut. Isolezwe has shown significant growth, nearly quadrupling its circulation since it appeared on the market (Media Club South Africa 2009; Bauer 2009).

The mainstream press in South Africa has thus undergone significant ownership changes in the last fifteen years. In the resulting, rationalized media market, allocative control is increasingly exercised in the interests of profit maximization. In the case of Independent News and Media Plc, there was little reason to expect otherwise. As an international media conglomerate with operations in four continents, any localization that has occurred has been a consequence of the search for additional globalized revenue streams

Of the two apartheid-era press houses, Naspers had supported gradual reform from the late 1970s onwards, as apartheid appeared to be getting in the way of further capitalist development. In the post-apartheid era, it appears to have found its niche market in catering to community consciousness amidst newly and previously alienated

\footnotetext{
${ }^{48}$ See Appendix 3 for 2008 circulation figures according to media group.
} 
audiences: Afrikaners and the black working class. Media24 is the sole publisher of Afrikaans papers. The end of National Party control over the public broadcaster likely contributed to the consequent expansion of this newspaper market (Jones 2002 as cited in Bauer 2009). The company's tabloids, pitched as "the People's Paper(s)", are credited with generating an entirely new readership - though not without controversy - in an age when newspaper readership is generally on the decline.

The Johnnic deal was one of the largest empowerment transactions, and gave rise to the highest expectations that allocative control would be used in a way to further substantial and fundamental changes within the industry. Yet these expectations were stunted by the very conditions which made the deal possible in the first place. Following its restructuring at the end of the 1990s, Johnnic Communications was able to enter on a path of sustained growth - giving rise to the question of whether black economic empowerment was about creating black media magnates.

The easy answer to this question gives way to the much harder question of what black economic empowerment was meant to achieve in regards to transformation - that is, in regards to the transition from unfair to fair discrimination, and eventually to a nonracial society; from a non-democratic dispensation to a democratic one; and from mass underdevelopment to development (Berger 2000). What is the role of the reformulated commercial free press in this process, particularly when allocative control is oriented towards capital accumulation, or put beyond the reach of reform efforts altogether, as in the case of the Independent News and Media Ltd? Where do black South Africans fit in, as citizens, readers, consumers and journalists? (unevenly incorporated into the country's political economy)? And what is the proper scope of government action in the realm of 
operational control, where it can exercise significant influence over editorial and general content and newsroom staffing? The final chapter will consider some of these questions, how they fuel current debates about press reform and why - namely because transformation has aimed to change the look but not the logic of capital. 


\section{Chapter 5 News and Journalistic Work in the New South Africa: Contemporary Issues}

The previous chapter demonstrated how the nature of ownership changes in the South African press and the push for reform surrounding them have been squeezed between the rock of limited democracy, on the one side, and the hard place of an increased push for profit-maximization, on the other. How does this squeeze between limited democracy and intensification of capital accumulation, in turn, influence operational control? That is, how does profit-orientation and the limits to reforms that go beyond the market impact decisions about the effective use of allocated resources and implementation of policy in the newsroom?

Answering these questions requires a structural analysis that looks at the limits to choice and pressures on decision-making (Murdock 1982: 125). Within a structural analysis, limits and pressures arise not only from allocative level decisions, but also from state action and policy towards the press. This chapter argues that dissatisfaction with the press industry's transformation is a function of the constrained institutional reforms that were examined in the previous chapter which have, in turn, placed substantial limits on journalists - in terms of their coverage of the new South Africa - and on government - in terms of its ability to influence reforms and implement policies within the industry. Moreover, beyond these constraints, significant obstructions to change also exist in terms of the day-to-day actions and decisions of journalists, editors and other media workers, or in other words at the level of operational control. I suggest that, having failed to achieve far-reaching changes at the allocative level, the government has placed greater pressure on the comparatively weak levers of operational control (editorial, staffing, and content). 
This focus on the operational level has consequently ensnared the government in highly sensitive issues that easily serve as an affront to liberal sensibilities regarding the sanctity of a free press and its fourth estate role.

Dissatisfaction with press transformation is evidenced in ongoing criticism of the press from a myriad of quarters. The most important controversies in South African journalism today revolve around the question of race, and whether the media should serve the public or national interest (Kruger 2004). As far as the racial composition of newsrooms is concerned, the staff profile of the press suggests that it has become far more representative of the country's demographics. Industry-wide statistics are, however, hard to come by. This is partly due to the different categories used to classify staff positions which makes tracking changes in newsroom demographics difficult (Berger 2001). While there have undoubtedly been significant improvements at the level of representation, changes at this level have been hobbled by the legacy of journalistic and editorial expertise built up under apartheid. In reality, such skills continue to be unevenly distributed along racial lines. In addition, companies across industries consistently fail to report their progress on targets set by the Employment Equity Act in terms of black and female hiring and their ascension up the corporate ladder (Rossouw 2005; Commission for Employment Equity 2009).

As of 2006, out of nineteen daily newspapers, there were nine white and ten black editors (Bauer 2009). Four prominent national English weeklies (Mail \& Guardian, City Press, Sunday Independent, and Sunday Times) also had black editors. In the same year the South African National Editors' Forum conducted a survey to track the status of women in the media, and considered race in its calculations. The Glass Ceiling (2006) 
report audited broadcast and print newsrooms, including those of Media24, Independent News, Johncom, the Citizen, and the Mail \& Guardian. It found that while black women constituted 46 percent of the population, they accounted for only 18 percent of newsroom staff, compared to black men, who constituted 45 percent of the population and 28 percent of newsroom staff; and white men who constituted 4 percent of the population and 28 percent of newsroom staff (SANEF 2006). Black men constituted 23.5 percent of top and senior management compared to 16 percent in 1999 , whereas black women accounted for six percent at this echelon (SANEF 2006). Thus white South Africans continue to be overrepresented in the country's newsrooms.

Disagreements over whether the media should represent the national versus the public interest are also a central debate in South African journalism, not least because their respective definitions are open to interpretation. Calls from government for a media that supports the national interest are a recurring theme in transitional societies with a recent history of violence and upheaval. Such appeals are based mainly on the fear that negative coverage and sharply opposing ideas can lead to yet further conflict (Voltmer 2006; Frohardt and Temin 2007). This is especially the case in countries where the media was used as a direct tool for inflaming tensions; the role of Radio Kangura in the Rwandan genocide being a prime example (Thompson et al 2007). National unity is presented as the antidote to a divisive past and the media, as a centre of substantial cultural power, is seen as crucial to overcoming divisiveness. The media's ability to harm the national interest is likewise focused on insofar as members of the old guard, opposed to change, remain in place. 
The media, for its part, seem to prefer the idea of serving the public interest (Kruger 2004). The public interest is often though not exclusively defined in relation to what the public should know, despite what the government wants it to know or focus on. Thus, in transitional societies, the debate pitting national against public interest is closely aligned with the debate between traditional watchdog journalism versus development journalism. In apartheid South Africa, communications media served the state, largescale capital, and the struggle. Members of the press, thus, now rightly, and jealously, guard their new-found freedom from state censorship at the same time that they must contend with increasing commercial pressures on their work. On the other hand, the ANC, as a movement turned political party, expects journalists to allow themselves to be harnessed to the greater good, as in the days of the struggle (Kruger 2004). Again, the idea of a "greater good" is open to interpretation.

These issues, of racial representation and national versus the public interest, fuel charges that developments in the country are being inadequately represented, while problems are white-washed. Allegations of racism in the media were particularly rife in the late- 1990s and led to a South African Human Rights Commission inquiry in November 1998. This was just a year after the Truth and Reconciliation Commission hearings into the role of the media under apartheid. The Human Rights Commission inquiry was as contentious as its predecessor. It demonstrates how the specific character of operational control- that is, the specialized knowledge of editors and journalists combined with liberal theories of the press make state interference in editorial matters taboo. This sensibility, however, can also serve as a shield to limit the investigation of legitimate concerns regarding how the press functions. 
Initial media coverage of the inquiry was overwhelmingly focused on the body's powers of subpoena, seen as anathema to a free press, and little coverage was given to examining the rationale for the inquiry. There was an uproar among media professionals who were concerned the inquiry would involve "snooping into newsrooms, demanding to know sources and doing a head-count on the basis of race" (SAHRC 2000: 49). In actuality, the inquiry had not considered it necessary to delve into the news production process; it felt that what happened in the newsroom could be judged by what the public read, heard or viewed (SAHRC 2000). This initial approach informed the briefs that the Commission gave to two independent researchers who were limited to surveying the products of the media. However, in addition to these research reports, the inquiry also held public hearings, and these revealed the extent to which the business of the mainstream press remained unchanged.

Speaking on behalf of a group of five black editors, Mike Siluma, then editor of the Sowetan, argued that "as a black editor or in particular as an African editor, you can either be assimilated and become part of the whole system or you can try to introduce that diversity and bring into play your own thing, your own experience and try to introduce that into the mainstream but that is a difficult thing because if you play along you will be fine" (SAHRC 2000: 21). Media participants recognized that the inflow of black journalists, mostly at junior levels, meant that the hierarchical organization of consultation in the newsroom had to change.

However, the impetus to change often came up against hard material realities. Independent News employee and Daily News editor Kaiser Nyatsumba noted that severe cost constraints limited his ability to make his newsroom representative: "you only have 
so many positions, you would have to wait until a vacancy exists" (SAHRC 2000: 33). All editors reported resource constraints and cuts to training budgets. They pointed out that many newspapers had become "mammoth business institutions with several layers of management like operations managers, general managers and so forth overseeing the commercial interests of the business" (SAHRC 2000: 35). Survival depended on editors having an interactive relationship with all levels of management. In sum, the report of the SAHRC inquiry pointed to the need to delve into the details of the industry, including ownership, advertising, newsroom practice, skills, and audience reception. I will shortly return to some of these and the challenges they pose to journalists in their day-to-day work.

Allegations of racism by the white-owned press towards the black government likewise led to the Task Group on Government Communications (Comtask). Comtask was charged with reviewing existing government communication policy, structure, facilities, budgets, training, its personnel and relationship with non-governmental information providers, as well as evaluating the ownership and control of the South African media and how it might affect government communication (Comtask 1996). To address ANC concerns that the media was biased against the government, the task group commissioned the Media Monitoring Project (MMP) to report on the extent and character of press coverage of the government.

The MMP research suggested that almost 80 percent of information generated in government did not reach the public via the media (Media Monitoring Project 1996). Its recommendations essentially offered advice to the government on how to improve its packaging of information to meet the established news values of media organisations. 
The importance of doing so was demonstrated by the finding that, when economic policy information in particular was not forthcoming or substantial, the media tended to "create its own supply out of the most innocuous remarks made by the [then] new Minister" (MMP 1996: 14).

The MMP analysis concluded that coverage of government between April and June 1996 was 49 percent neutral, 30 percent positive, and 21 percent negative (1996: 1). The Presidency received the most coverage, followed by the Constitutional Assembly and the Ministry of Finance. Although the media did give ample coverage to significant changes occurring in government, there was a preference for political over policy stories, focusing for example on allegations or probes into corruption rather than actual work being done by a ministry. Overall, the bulk of the final Comtask report focused on restructuring the government communication apparatus, not only in its relations with commercial media but also with the public not serviced by this media. In effect, government was advised to cater to the media's newsgathering process. The problem is that this process remains suspect and is contingent upon decisions geared towards profitmaximization and the bottom line.

\section{Watchdog versus “Merchant of Chaos": Western Liberal News Values}

What South Africa requires of a free press is what the profession has long claimed as its mission: to inform, educate, and entertain, no more, no less. The constraints placed on press reform and the lack of a national media policy has meant that the country's media system continues to be dominated by the logic of capital - not unlike the media in the established democracies of the West. As a result, political opinion has been sucked 
towards the political center with newspapers offering similar opinions (Duncan, personal interview, 28 July 2008). While journalists have gained some measure of (political) freedom, continued material limits contribute to journalists exercising this freedom without due regard to their responsibilities to their readers, their craft, and the difficult conditions facing the country. Adherence to traditional news values and the way the audience commodity segments readers according to income often results in news that is superficial, simplistic, stereotypical, and condescending towards its audience validating, to an extent, press critics who charge that coverage of black South Africans is racist and one-dimensional.

Western liberal news values are based in material realities: government sources and other institutional figures are the go-to for news that is relatively cheap and easy to gather, and easily verified (Herman and Chomsky 1988). As a result, these sources become "authorized knowers", and formal government interactions and processes come to dominate what is considered political news. Given the range of issues that must be tackled in South Africa, there is a need for journalists to "authorize" more "knowers". According to one journalist, government sources can be useless in providing useful information:

We did a story about a school in the CBD [Central Business District] and how unsafe it is because it's a primary school in the middle of that whole area ${ }^{49} .$. Our editor says 'Speak to the Department of Education'... how about I speak to the parents first?' Because surely there are options, and there are ways that the parents and whoever is interested in the school, that they can actually hook up something for these kids to not be hanging around town before we need to bring in the government ... you always have to have the government commenting on the story. I don't get that. And they'll always always not know what to say,

\footnotetext{
${ }^{49}$ Where Johannesburg has a reputation as one of the world's most crime-ridden cities, the Central Business District is its "no man's land" - at least as far as white South Africans and tourists are concerned. When crime rates spiked in the 1990s, many of the businesses migrated to northern suburbs. However, as the quote illustrates, people live, study and work there.
} 
because they don't know what fucking school you're talking about and they'll say 'Well, give me five days,' 'I don't have five days,' 'Well I don't have an answer.' Then we don't have a story. But it's still an issue though. (Nandipha, personal interview, 29 July 2008)

A dependence on government and official sources is part of a larger tendency to go for the quick, cheap and easy to produce story. This tendency is inherent to the concept of "news", where the commodification of information depends on its novelty, as discussed in the opening chapter (Garnham 1990). This persuasion towards the easier story means that not only certain sources, but also certain stories garner more attention than others: for example, the tsunami of 2004 over Uganda's 18-year civil war (Thompson 2007). The one is a relatively simple storyline of a natural disaster with no one to blame, while the other represents a complicated relationship of people and motives.

Persistent media pressure is often credited with ensuring that "something happens" and that someone or some group of people will take responsibility. But the news business is inherently fickle; and in being so, they may be missing the story as far as affected citizens are concerned. Consistent coverage of an issue is no guarantee that action will be taken, but if anything will generate policy action, it will be more coverage, not less (Thompson 2007). Take, for example, the story of a hospital in Umtata, Eastern Cape, one of the country's poorest provinces; a new health complex was built and patients and services were transferred, while the older hospital was left, fully functional but not in use, for several years: "So you go and do the story . . . then I say next week, 'what now? I mean surely we need to find out what's going to happen to it?' Now that's not a story" - at least not in terms of traditional news values (Nandipha, personal interview, 29 July 2008). But it is useful information for those directly affected in that community. 
Another example is media coverage of HIV/AIDS. South Africa is experiencing one of the most severe epidemics in the world, yet the issue receives less than 1 percent of all media coverage (Media Tenor 2005). More substantial and educational coverage of HIV/AIDS that addresses prevention, testing, awareness and socio economic effects, has a limited value in the news commodity market, where it is considered too common and too depressing: "AIDS doesn't sell; you can't put AIDS on the front page" (Monama, journalist, personal interview, 1 August 2008). It is old news and there is only so many ways one can cover it (Kamang, journalist, personal interview, 26 July 2008). Yet, apart from coverage of Mbeki's initial denialist stance on the pandemic and related clashes, HIV/AIDS coverage has never reached a point of saturation (Media Tenor 2005). Minimal to no coverage combined with conflicting government messages have contributed to the further stigmatization of those affected (Avert 2009).

These commercial pressures to report on scandal and the personal desire of journalists for professional prestige are active factors in old and new democracies alike (Matos 2008). In South Africa, the interplay between commercial pressures and the new democratic dispensation have led to highly personalized coverage of politics. So, for example, during the 1999 elections, South African newspapers largely adopted the horserace portrayal of elections typical of North American media (Jacobs 1999). This type of coverage renders readers passive bystanders to a spectacle, not citizens participating in a democratic exercise. News culture, in this case, reinforces the institutional pivots of limited democracy. Issues-based coverage was neglected in favour of vote-catching events and a focus on personalities, although with limited effect. Campaigning through the print media was thus most effective for parties targeting minorities, while the majority 
ANC could still use traditional means of campaigning, such as the mass rally and organizational contacts, to great effect (Jacobs 1999).

As it stood, voters' assessment of issues differed significantly from that offered by the media: the latter pointed to immigration, land, rates and taxes, wages, the environment, the death penalty, discrimination and affirmative action as important issues; none of these were cited by more than 2 percent of survey respondents, large majorities of whom pointed to job creation and unemployment, crime and security, with housing and education the next two most cited (Idasa-Markinor survey, as cited in Jacobs 1999: 149).

In day-to-day practice, a focus on watchdog journalism, combined with the idea that "good news doesn't sell", has resulted in the South African press falling short of its responsibility to educate and inform. The media frequently fails to recognize the difference between supporting the government's political aims and informing the public of the functions of government and how it can work for them (Kruger 2004). This shortcoming, along with the press's shallow penetration of the overall population, was manifest in Comtask recommendations that government increase its unmediated communication in order to reach those parts of the population not served by commercial media (Comtask 2000). "Communicating government" has thus entailed not only a sharper approach to press relations but also an approach that bypasses the commercial press altogether, both of which only serve to further antagonize the already conflicted relationship between the press and government. 


\section{The audience commodity}

In terms of shallow audience penetration, newspapers, as a medium requiring both literacy and a certain amount of leisure time, tend to be limited to those in the middle- to upper-income brackets of a society. They generally address the decision-making publics in a given society (Matos 2008). Their elitism is exacerbated by a reliance not just on circulation sales but also on the revenue gained from selling advertising space. "Adspend" accounts for two-thirds of a paper's overall revenue (Fourie 2004). Advertisers are typically interested in readers with disposable income, the more the better. In South Africa this reality fuels criticism that newspapers continue to operate within a white paradigm, notwithstanding the growing black middle class, and do not reflect the lives and issues of a majority of its citizens. The Human Rights inquiry referred to earlier reported that high circulation black-oriented papers, such as the Sowetan, still struggle to attract advertising worthy of its size because ad agencies continue to operate on the basis that black readers belong to lower class and thus unattractive income categories (SAHRC 2000).

The Human Rights inquiry and Comtask both published their reports in 2000 . Since this time, South Africa's black middle class has grown further and the advertising industry's approach to black consumers has changed. In 2006, TNS Research Surveys (Pty) Limited and the University of Cape Town Unilever Institute coined the term "Black Diamond" to refer to members of South Africa's "fast growing, influential and affluent black community" (TNS Research Surveys 2008). In the media, "black diamond" is now used interchangeably with "black middle class" and this group is estimated to number 3 
million, out of a total population of 48.7 million (Naidu 2008; Statistics South Africa 2008).

Newspaper readership (as opposed to circulation or copies sold) has also increased: 48.4 percent of all media consumption is through newspapers (All Media and Products Survey 2008a: 1). However, market penetration remains limited to middle- and upper-income brackets, with a few significant exceptions, to be discussed shortly. In South Africa, newspapers typically profile their readers according to the Living Standard Measure (LSM) developed by the South African Advertising Research Foundation. The LSM uses criteria such as degree of urbanisation and ownership of cars and major appliances to divide the population into ten groups, where LSM 10 represents the highest living standard and LSM 1 the lowest (SAARF 2006). In terms of this measure, newspaper and readership generally falls between 7 and 10 LSM with little to negligible penetration below $6 \mathrm{LSM}$; readership profiles usually group LSMs 1 to 5 into a single percentage of total readership.

The growth of South Africa's tabloid press is a significant exception to this view of newspapers as an elite medium. The Daily Sun has been credited with penetrating LSMs 4 to 6 (Duncan, personal interview, 28 July 2008). The Sun has thus expanded the audience commodity, but its success is not without controversy. On the one hand, ethics, intent and the Sun's use of graphic images are an issue. Critics charge that its content exploits the fears and superstitions of a sizeable poor and uneducated black population. Witchcraft, tokoloshes ${ }^{50}$, and graphic images are standard fare (Townsend 2006; van Riet and Roberts 2008). On the other hand, the Sun's typical coverage, objectionable as its

\footnotetext{
${ }^{50}$ In Zulu mythology an evil and mischievous spirit that rapes people at night while they are sleeping. See South African Press Association (2009).
} 
language and visuals may be, portrays the reality of township life in contrast to other mainstream media, which tune in only when such realities begin to encroach on life outside these poor and largely under-developed areas (Harber 13 June 2008).

The Sun regularly interacts with its readers for stories: "the call centre for the Daily Sun is bigger than their newsroom... Suddenly you get this thing that comes into a community and they publish your story, you're famous, you're in The Daily Sun" (Bird, personal interview, 16 July 2008). There is also evidence of a level of community consciousness within its coverage: "they' re trying to be of service, to some extent, to what they see as their community, and that's good. I mean, that can't be bad, at the end of the day. It depends of course what sort of values you also then promote along with that" (van der Westhuizen, personal interview, 18 August 2008). For example, Media Monitoring Africa has taken the paper to the Ombudsman over its use of the word "alien" in relation to coverage of non-South Africans and the outbreak of xenophobic violence in May 2008. It has also commended the Sun for its positive coverage of children and for drawing attention to the issue of forced marriages (Media Monitoring Africa 2009).

There are indications that the Sun has expanded not only newspaper readership but literacy: "they write well; I think they write really ... very simple to understand. My uncle is reading The Daily Sun because he wanted to learn English. And his English is improving" (Monama, journalist, personal interview, 1 August 2008). There are other educational features to the paper: while the first few pages are dedicated to the sensational stories and photos typically associated with its tabloid format, it features a small section on English idioms as well as regular sections on personal finance, career 
and health advice. Nonetheless, the debate over whether the Sun is exploiting or providing a service to South Africa's black working class continues.

Bypassing the elite and tabloid press, the unmediated communication strategy of the Government Communication Information Service is aimed at LSMs 1 to 4 . A central feature of this strategy is imbizo, a Zulu word that means "gathering" or "meeting". The government launched its Imbizo programme in 2001 with the aim of "enhancing dialogue and interaction between senior government executives and ordinary people" (Republic of South Africa 2009). The programme is comprised of focus weeks, where the Deputy President, Cabinet and Deputy Ministers, Premiers, Members of Executive (provincial) councils, and local government representatives visit municipalities to communicate the government's policy and initiatives and discuss service delivery, among other issues. Similary, presidential imbizo include the President in visits to municipalities. In this way, the country's less- to least-serviced audiences have a measure of access to decisionmakers in government - but not to the unelected decision-makers whose economic and/or organizational clout weighs in to pre-parliamentary decision-making. As long as these publics remain isolated from each other, transformation of apartheid capitalism's underclass will be stunted, and media critics will continue to point to the press as untransformed and against change.

\section{Goverment Response}

Dissatisfaction with press transformation and the government's limited ability to initiate substantial reform have resulted in largely reactive government measures. Before 
considering these measures, it is useful to look at the self-regulatory mechanisms provided for by industry and some of the debates it has occasioned.

The press set up a self-regulatory mechanism in 1997 and has since made changes to include members of the public in its work and to raise the profile of the office. The mechanism is comprised of the Press Council, the Press Ombudsman and a Press Appeals Panel, which is equally split between members of the press and the public, with a judge for chair. More than 640 publications subscribe to the Press Code and newspapers now make reference to it usually within the first couple pages of the paper.

The adequacy of print media's self-regulation continues to be a prominent and highly sensitive issue, given the history of government censorship under apartheid. Liberal theories of the importance of a free press are exemplified by such historical examples, and this often appears to make self-regulation, however flawed, preferable to any government intervention. At the same time, the profit-orientation of the English press, not wholly under the thumb of the apartheid government, and the big business of media in the post-apartheid era, call into question just whose interests are protected by the sanctity of press freedom. One area of contention pertains to legal action and redress. The Complaints Procedure sets outs that the Ombudsman will not accept a complaint where legal action is threatened or is considered by the Ombudsman to be a possibility, unless the complainant waives their right to claim civic relief (Press Council 2007). The Press Council defends this as guarding against the possibility of people using the selfregulation system in bad faith, to become aware of the publication's defence and use the information against it in the courts. 
The office does not have the power to call on an offending party to pay damages, but can order the offending publication to publish an apology and can also stipulate the apology's placement in the paper; the Ombudsman's rulings are also often covered by the media. Some are of the view that the process should be dispensed with altogether and press code breeches should be dealt with by the judiciary. In this regard, journalist Mzwandile Kamang argues that papers should be willing to put their money where their mouth is: "[i]f you say 'what we've printed is fact ... we've tried to establish fact, that's why we've printed it,' then the newspaper should not be scared of being taken to court where they might, if they are wrong, lose 200 000" (personal interview, 26 July 2008).

Another area of contention is that the process is reactive as opposed to proactive. Here again the taboo against strong regulation is challenged by perceptions of a licentious commercial press. The current Press Ombudsman, Joe Thloloe, argues that the onus is on the public to be vigilant about their press quality: "You get publications you deserve. If you don't complain about what you read, it says you are happy with it" (personal interview, 8 August 2008). Conversely, Themba Maseko, Chief Executive Officer of the Government Communication and Information System, feels the office should be able to take issue with a newspaper that is transgressing from the agreed rules ${ }^{51}$, even if there is no formal complaint (personal interview, 13 August 2008). Consequently, Thloloe has tried to raise the profile of the office and its work among members of the press and public alike in order to enhance its credibility as the institution best-placed to handle regulation.

The ANC-dominated government has responded to perceptions of inadequate and hostile coverage with what have sometimes appeared to be Draconian measures, reminiscent of policy instruments of the old South Africa. Some of these measures place

${ }^{51}$ As outlined in the South African Press Code. 
blame squarely at the feet of newspaper owners, as the ANC did in 2007, for example, by singling out the inadequacies of the industry's self-regulation measures and blaming the skills shortage within the industry on owners who, in their view, have pursued profits over quality journalism. As such, the party resolution called for a statutory media appeals tribunal that would be accountable to parliament and which would complement the work of the Press Council (African National Congress 2007). Media professionals that I spoke with felt that the proposal was an affront to constitutionally-protected press freedoms, and were genuinely concerned about the state's willingness to flex its muscles.

Indeed, there are worries in some quarters of a creeping authoritarianism, a sense bolstered by the government's increased use of libel law, attempts to re-regulate the media, and increased control over government communication (Millard 1998; Blankson 2007; Waldorf 2007). In South Africa these moves fill the void left by inadequate media reform. They represent a sliding scale from intimidation, to constricting freedom of expression and information, and finally to the strict "management", or severing, of access to information at the source (government). Libel suits target licentious coverage but, if used extensively and successfully, they can cripple the media's investigative efforts and result in newspapers avoiding coverage that could be construed as unduly critical. Such a result depends on the resources media organizations have to defend themselves against such charges, and how prepared those who control the allocative purse-strings are to fight the suits in the first place. For example, Zuma's use of defamation law and the millions of dollars he is claiming for damages is making legal history in the country. Although these relate to his trial on rape charges, of which he was subsequently acquitted, many in the ANC leadership have repeatedly claimed that Zuma has been tried in the court of 
public opinion in relation to the arms deal (Brown 2008). Zuma has settled out of court on three matters, and has dropped the defamation components of certain claims while retaining the elements related to attacks on his dignity (Smit 2008).

In terms of attempts to re-regulate the media, from the turn of the millennium onwards, the South African government has introduced several legislative measures that are pertinent to the industry, such as the Anti-Terrorism Act, the Film and Publications Bill, and the Protection of Information Bill. These bills have, to some extent, been part of a larger undertaking to review, repeal, and reform apartheid-era law. However, concerns have surfaced as to how much these bills represent attempts to bring South African law books in line with the new constitution versus an effort to replicate the Draconian tools of the old South Africa. The anti-terrorism legislation, in particular, had a very contentious and overly-broad definition of a "terrorist act", defined in part as that

which is intended, or by its nature and context, can reasonably be regarded as being intended, in whole or in part, directly or indirectly to intimidate, or to induce or cause feelings of insecurity within the public, or a segment of the public, with regard to its security, including its economic security, or to induce, cause or spread feelings of terror, fear or panic in a civilian population. (Republic of South Africa 2003a: 8-9)

Issue was taken with three incarnations of the bill between 1999 and 2003; it was shelved in 2004 when the Congress of South African Trade Unions, a member of the governing alliance, threatened a national strike and constitutional challenge to the bill should it become law.

The Film and Publications Amendment Bill sets out to amend the original Act of 1996 with the putative aim of bolstering the protection of children against pornography and preventing the incitement of hatred. It calls for pre-publication examination and classification of material containing violent, degrading or disrespectful sexual conduct, or 
which incites war or hate-based violence. Section 16(1) allows an exemption for "bona fide newspapers" (recognized by the Press Ombudsman and which subscribes to a code of conduct), although section 22 allows this exemption to be repealed on a case-by-case basis (Republic of South Africa 2006a).

Similarly, the Protection of Information Bill was meant to repeal the 1982 Act of the same name and replace it with one in line with the principles of the new constitution. The bill opens access to all information classified prior to 10 May 1994, although a key weakness of the bill is that all events since that time, such as the entire arms deal debacle, are excluded from public view (Freedom of Expression Institute 2008). Another area of concern is the overly broad definition of "national interest" and information that requires protection from disclosure. National interest includes "the pursuit of justice, democracy, economic growth, free trade, a stable monetary system and sound international relations" (Republic of South Africa 2008). Clearly, reason for concern is raised by such broad notions, not just among members of the press but among society as a whole.

Dissatisfaction with press coverage has also led the government to withdraw and tighten its control over the flow of information. This affects not just government-press relations but the information environment as a whole. The Government Communication and Information System (GCIS) was one major result of the Comtask inquiry. It was meant to streamline how government communicates. Since 1998 it has centralised government communication strategy and acts as an information portal. This system can both facilitate and impede media's interaction with government. As one interviewee suggested, "the bigger their information system becomes, the more difficult [it] becomes to get information, because the way that it's set up, you can never go to the actual source, 
there's always an intermediary" (Brand, journalist and professor, personal interview, 21 August 2008). While relations with certain people in government can be good, the hierarchy retains significant clout: "the people below the communications director, they're nice people. They will talk; but everything has to go through her first" (Monama, journalist, personal interview, 1 August 2008). Lack of information from government, combined with news values that favour government sources, feeds highly speculative reporting and an increased use of confidential sources. The extent of this use is such that the Ombudsman has seen a marked increase in complaints that question the integrity of such confidential sources and whether they do in fact exist (Thloloe, personal interview, 8 August 2008).

As a result of these dynamics, the tone, content and credibility of the press are increasingly at issue, and the relationship between the industry and the government has become ever more fractious. Dissatisfaction with press transformation and the government's controversial attempts to compel more tangible and substantial change are rooted in the limits built in to the country's democratic dispensation, discussed in the previous chapter. Multi-racial democracy remains tied to historically given and constitutionally-protected property relations. These constrain both the path of general institutional change as well as the operational parameters within which journalists ply their craft such that suggested government remedies to the perceived short-comings of the press increasingly fly in the face of what liberal theories demand in terms of press freedom. In this way, the resulting debates about press reform represent a profound questioning of post-1994 democracy. 


\section{Chapter 6 Conclusion}

This thesis has been concerned with the limits placed upon democratic change in the new South Africa and the affect these limits have had on the country's press industry. I have argued that debates over the lack of transformation in the press and the scope of reforms are symptomatic of continuities between the "old" and "new" South Africa. Historically, the South African press developed along axes of profit and politics, where black and white groups, to varying degrees, harnessed cultural power to generate, and justify their claims to, political and economic power. In the post-apartheid era, calls for a more patriotic press that contributes to nation-building come up against this legacy, overshadowing what potential does exist for communicating the various functions, and benefits, of democracy.

Of course this thesis has also shown some of the limits to democracy in an age of global capitalism. These limits prevented a more comprehensive redistribution of resources and, in so doing, perpetuate the exclusions of the old South Africa, a continuity that is mirrored in the mainstream press. Under apartheid, the profit imperatives of the mainstream press, in combination with state censorship, by and large denied black citizens a mass and mainstream platform for opposing their marginalization within the country's political economy. As the previous chapter noted, there is considerable evidence to suggest that today profit imperatives interact with market censorship to achieve a similar result in relation to the large numbers of black citizens still waiting to benefit tangibly from the new dispensation. 
These continuities, in the distribution and logic of capital, in systems of political and economic exclusion, and in the influence of foreign-held capital on the domestic political economy, limit the depth and pace of transformation. On the one hand, such continuities may have contributed to a relatively peaceful transition that enjoyed international approbation. On the other hand, however, the deteriorating pitch and tone of government-press relations may be a signal of troubles ahead. Additional analysis of opportunities within the country's current distribution of political and economic power may provide a way through the apparent impasse that its past and limited commitment to a more thorough-going democracy have created. The following is a preliminary analysis of how the press might harness the changes that have occurred in South Africa to this end.

By the end of the 1990s all English-language papers, black-edited or not, had expanded their coverage to be much more representative of black South Africans than they had ever been. Whether out of economic necessity or democratic will and however unsatisfactory, the change does represent an expansion of news values, however basic (Tomaselli 2002). The question is how much further can these values be expanded and under what circumstances? To what extent can the diversity of the newsroom reflect the diversity of the country, its people, and their interests?

The answers to these questions lay at the heart of the relationship between black economic empowerment and the media industry. Government assumptions have been that a black-owned and black-operated press would be more supportive and reflective of the "black" experience (Tomaselli 2002). Those who "know better", it had been hoped, would correct skewed coverage. Times Media Chairman Cyril Ramaphosa, for example, 
and in response to the racism inquiry, argued that the flagship Sunday Times was "a newspaper of preference for the country's multi-lingual elite' [which] would not be attracting such a growing number of black readers if it was propagating racism" (SAHRC 2000: 24). The paper had moreover "recruited senior black staff from whom it would be inconceivable to see the advancement of racist material" (SAHRC 2000: 24).

At the same that this commentary eschews racism, however, it is an exchange where the value-laden binaries of black versus white continue to loom large. The need to challenge stereotypes continues to be a persistent legacy of the country's racial divides. However, another opposition needs to enter the conversation: namely, that of upper class versus the lower class. Lower-class blacks have yet to materially benefit from ANCdominated rule, and newspapers, including some of those previously outspoken in their opposition to apartheid, continue to ignore the concerns and, perhaps more importantly, the perspective of the black working class (Tomaselli 2002). The Daily Sun's focus on this group has been the key to the paper's rapid success over all other commercial papers.

Can other mainstream papers replicate the Sun's success without falling into some of the paper's ethical dilemmas? Is there a way for a commercial press to better meet its democratic responsibilities to inform and educate? I believe there is, and that the solution is not limited to the boardroom. This thesis has undertaken a structural analysis in order to look at the limits to choice and pressures on decision-making as they exist in South African press and politics. An "action" analysis looks at the range of possibilities within limits and choices and between them (Murdock 1982: 125). Here, biographies and the interests of key decision-makers are important: "Capitalists . . are not unified subjects. A given person or group can only be described as a capitalist in those moments when 
each is acting in conscious and willed accord with the logic of capital accumulation" (Garnham 1990: 35). Similarly, black South Africans are not unified subjects; the "black" experience is fragmented along lines of class, gender, ethnicity, language, and geography, to name a few (Tomaselli 2002). An understanding that "black" is not synonymous with "representative" is yet another step away from the logic of apartheid. In this way, racial capitalism and black economic empowerment can be viewed as two sides of the same coin. Tossing the coin calls for redressing past inequality and injustice without falling into the trap of racial essentialism.

In the newsroom, this means representing and relaying diversity in all its forms. It is not just about numbers but about changing mindsets and organizational structures (Rossouw 2005). In some cases this will oblige journalists to "crawl outside their skin" and their comfort zone in order to exercise their role fully (Thompson 2007: 439). In other cases, it will require that journalists be empowered to portray their communities faithfully, for better or for worse, without being subject to charges that in doing so, they necessarily surrender their objectivity. As one journalist said, "the market is the people we go home to" (Nandipha, personal interview, 29 July 2008). In all cases, it requires newsrooms to take charge of the control they do have to demonstrate that there is an audience and a market for a different kind of news.

This has already been done in South Africa to a certain extent. Black journalists entering white-dominated newsrooms in the 1990s by and large had less training and experience than their white counterparts, and the majority of them were incorporated into junior positions. At the same time, these black journalists contributed to a majority that was now influential in all matters affecting the country. Many editors recognized that 
newsroom dynamics had to change in order to not only represent but communicate the new South Africa (SAHRC 2000). This entailed, among other things, flattening hierarchical structures and including junior staff members in news conferences. This has not necessarily happened uniformly across newsrooms, but to the extent that it has, it demonstrates that given material realities are amenable to human action: " $[\mathrm{t}] \mathrm{he}$ future, though it is not entirely open, is not entirely closed either" (Lukes 1974 as cited in Murdock 1982: 133).

Control, as with power, "is not a quantity but a social relation" (Murdock 1982: 133). The extent to which South African journalists are able to work upon this relation may just be the litmus test for measuring the empowerment of the newsroom and the transformation of the industry. Under apartheid and despite all the efforts of the minority, capital proved vulnerable to the resistance, interaction and aspirations of different groups; it should be more malleable under the new dispensation. In the press industry, this depends not only on the varying interests and identities of those controlling capital but on the extent to which the multiple interests and identities in the newsroom are able to grapple, with each other, and the issues. There is also a need for both government and the press to step back from their allegiances and examine what their duty is to society (Kruger 2004). While constructive engagement between government and the media usually verges on taboo, "there is still a need for propaganda in South Africa . . at the simple level of publishing news and information people need to make them truly free (Rossouw as cited in Kruger 2004: 31). If the South African media can strike this balance, it may just reinvigorate understandings of what press freedom entails and how it can broaden the horizons of modern liberal democracy. 


\section{Appendix 1 Newspaper Ownership circa 1950}

\begin{tabular}{|l|l|l|l|}
\hline $\begin{array}{l}\text { Argus Printing and } \\
\text { Publishing } \\
\text { Company }\end{array}$ & $\begin{array}{l}\text { South African } \\
\text { Associated } \\
\text { Newspapers } \\
\text { (SAAN) }\end{array}$ & Naspers & Perskor \\
\hline $\begin{array}{l}\text { Cape Argus } \\
\text { The Star } \\
\text { The Natal Daily }\end{array}$ & $\begin{array}{l}\text { Rand Daily Mail } \\
\text { The Sunday Times } \\
\text { Weekend World } \\
\text { Sunday Post } \\
\text { Diamond Fields } \\
\text { Advertiser } \\
\text { Imvo Zabantsundu } \\
\text { The Pretoria News } \\
\text { The World } \\
\text { Post }\end{array}$ & $\begin{array}{l}\text { Die Burger } \\
\text { Die Transvaler }\end{array}$ & $\begin{array}{l}\text { Ons Vaderland } \\
\text { Dagbreek } \text { en } \\
\text { Sondagnuus } \\
\text { Imvo Zabantsundu }\end{array}$ \\
\hline
\end{tabular}


Appendix 2 Newspaper Ownership in 1990 and 2008

\section{Newspaper Ownership 1990}

\begin{tabular}{|c|c|c|c|}
\hline $\begin{array}{l}\text { Argus Newspapers } \\
\text { Ltd }\end{array}$ & Times Media Ltd & Naspers & Perskor \\
\hline $\begin{array}{l}\text { Cape Argus } \\
\text { Daily News }\end{array}$ & \multirow{3}{*}{$\begin{array}{l}\text { Business Day } \\
\text { Cape Times } \\
\text { EP Herald } \\
\text { Evening Post } \\
\text { The Sunday Times }\end{array}$} & \multirow{3}{*}{$\begin{array}{l}\text { Beeld } \\
\text { Die Burger } \\
\text { Volksblad } \\
\text { Rapport } \\
\text { City Press }\end{array}$} & $\begin{array}{l}\text { The Citizen } \\
\text { Imvo Zabantsundu }\end{array}$ \\
\hline The Star & & & independent \\
\hline $\begin{array}{l}\text { Isolezwe } \\
\text { Sowetan } \\
\text { Sunday Tribune } \\
\text { Saturday Star } \\
\text { Saturday Argus } \\
\text { Sunday Argus }\end{array}$ & & & $\begin{array}{l}\text { Daily Dispatch } \\
\text { Ilanga Lase Natal } \\
\text { The Witness } \\
\text { The Weekly Mail }\end{array}$ \\
\hline
\end{tabular}

Newspaper Ownership 2008

\begin{tabular}{|l|l|l|l|}
\hline $\begin{array}{l}\text { Independent } \\
\text { Newspapers }\end{array}$ & $\begin{array}{l}\text { Avusa (formerly } \\
\text { Johncom) }\end{array}$ & $\begin{array}{l}\text { Media24 } \\
\text { (Naspers) }\end{array}$ & Caxton/CTP \\
\hline Cape Argus & & & \\
Cape Times & Beeld & The Citizen \\
Daily News & Die Burger & Saturday Citizen \\
Diamond Fields & Daily Dispatch & Daily Sun & \\
Advertiser & The Herald & Ilanga & \\
Isolezwe & Sowetan & Kaapse Son & \\
The Mercury & Saturday Dispatch & Volksblad & \\
Pretoria News & The Sunday Times & The Witness & \\
Sowetan & Sunday World & Weekend Beeld & \\
The Star & Weekender & Saturday Burger & \\
Saturday Argus & Weekend Post & City Press & Newtrust Company \\
Sunday Argus & & Rapport & Son \\
Independent on & & Sunday Sun & Motswana Ltd \\
Saturday & & Saturday Volksblad & \\
Isolezwe nge Sonto & & & \\
Post & & & \\
Saturday Start & & \\
Sunday Independent & & & \\
Sunday Tribune & & & \\
& & & \\
\hline
\end{tabular}




\section{Appendix 3 Circulation Figures 2008}

Media24

\begin{tabular}{|c|c|c|}
\hline Beeld & 101972 & 575000 \\
\hline Die Burger & 80200 & 511000 \\
\hline Daily Sun & 513291 & 5161000 \\
\hline Kaapse Son & 105400 & 486000 \\
\hline Volksblad & 26800 & 103000 \\
\hline The Witness & 24561 & 126000 \\
\hline TOTAL DAILY & 852224 & $52 \%$ \\
\hline Weekend Beeld & 87900 & 347000 \\
\hline Saturday Burger & 99100 & 556000 \\
\hline City Press & 197112 & 530000 \\
\hline Ilanga Langesonto & 86507 & not avail \\
\hline Rapport & 296237 & 1582000 \\
\hline Son & 217999 & 554000 \\
\hline Sunday Sun & 176282 & 3063000 \\
\hline Saturday Volksblad & 22400 & 144000 \\
\hline TOTAL WKLY & 1183537 & $44 \%$ \\
\hline TOTAL & 2035761 & $47 \%$ \\
\hline
\end{tabular}

Avusa Ltd

\begin{tabular}{|c|c|c|}
\hline Business Day* & 40000 & 118000 \\
\hline Daily Dispatch & 31600 & 294000 \\
\hline The Herald & 25100 & 245000 \\
\hline Sowetan & 130000 & 2097000 \\
\hline TOTAL DAILY & 226700 & $13 \%$ \\
\hline Saturday Dispatch & 25600 & 164000 \\
\hline Sunday Times & 504400 & 3896000 \\
\hline Sunday World & 181200 & 921000 \\
\hline Weekender* & 14300 & 94000 \\
\hline Weekend Post & 25600 & 164000 \\
\hline TOTAL WKLY & 751100 & $28 \%$ \\
\hline TOTAL & 977800 & $22 \%$ \\
\hline
\end{tabular}

Independent News \& Media (SA)

\begin{tabular}{|c|c|c|}
\hline Cape Argus & 63200 & 359000 \\
\hline Cape Times & 48800 & 272000 \\
\hline Daily News & 41900 & 325000 \\
\hline Diamond Fields Advertiser & 9900 & 70000 \\
\hline Isolezwe & 99100 & 655000 \\
\hline The Mercury & 37100 & 185000 \\
\hline Pretoria News & 26400 & 220000 \\
\hline The Star & 156900 & 1081000 \\
\hline TOTAL DALY & 483300 & $29 \%$ \\
\hline Saturday Argus & 97400 & 312000 \\
\hline Sunday Argus & 97400 & 251000 \\
\hline Independent on Sat & 60568 & 205000 \\
\hline Isolezwe nge Sonto & 48000 & not avail \\
\hline Post & 47400 & 349000 \\
\hline Weekend Pretoria News & 16803 & 151000 \\
\hline Saturday Star & 120200 & 542000 \\
\hline Sunday Indep. & 40100 & 243000 \\
\hline Sunday Tribune & 95700 & 651000 \\
\hline TOTAL WKLY & 623571 & $23 \%$ \\
\hline TOTAL & 1106871 & $25 \%$ \\
\hline
\end{tabular}

Caxton/CTP

\begin{tabular}{|} 
The Citizen & 67600 & 496000 \\
\hline \multicolumn{2}{|c|}{ TOTAL DAILY } & $\mathbf{6 7 6 0 0}$ & $0.04 \%$ \\
\hline Saturday Citizen & 52200 & 732000 \\
\hline TOTAL WKLY & 52200 & $0.01 \%$ \\
& $\mathbf{1 1 9 8 0 0}$ & $0.02 \%$ \\
\cline { 2 - 2 }
\end{tabular}

Newtrust Company Botswana Ltd

\begin{tabular}{|r|c|c|}
\hline Mail \& Guardian** & 58300 & 500000 \\
\hline TOTAL WKLY & 58300 & $0.02 \%$ \\
TOTAL & 58300 & $0.01 \%$
\end{tabular}

* Pearson PLC (UK) holds 50\% of Business Day and Weekender through BDFM

** Trevor Ncube owns Newtrust Company which holds 87 percent of Mail \& Guardian; The Guardian (UK) holds 10 percent of the paper

Circulation figures from Audit Bureau of Circulation Oct-Dec 2008.

Readership figures from South African Advertising Foundation All Media Product Survey 2008a. 


\section{Bibliography}

Adam, H., Van Zyl Slabbert, F., \& Moodley, K. (1997). Comrades in Business: PostLiberation Politics in South Africa. Cape Town: Tafelberg Publishers.

African National Congress. (1997, July). The Core Values of the RDP. Retrieved from http://www.anc.org.za/ancdocs/discussion/rdp.html

African National Congress. (1997, September). The Role of Media under Apartheid: African National Congress Submission on Media to the Truth and Reconciliation Commission. Retrieved from http://www.anc.org.za/ancdocs/misc/mediasub.html

African National Congress. (2007, December). Communication and the Battle of Ideas. Retrieved from http://www.anc.org.za/ancdocs/history/conf/conference52/resolutions.pdf

Anglo-American. (n.d.). History. Retrieved November 14, 2007, from http://www.angloamerican.co.uk/article/?afw_source_key=19ED07F3-C5AB427C- BACE-6DABAC9037A7

Arendt, H. (1965). Eichmaan in Jerusalem: A Report on the Banality of Evil, revised edition. New York: Viking.

Aristotle. (1981). The Politics. (T. Sinclair, Trans.) London: Penguin Books.

Avert. (2009). HIV and AIDS in South Africa. Retrieved from http://www.avert.org/aidssouthafrica.htm

Avusa Limited. (2001). Annual Report. Retrieved January 30, 2008, from http://www.johncom.co.za/investment/results/default.aspx ?pageid=301860

Avusa. (2009). Avusa Businesses Overview. Retrieved from http://www.avusa.co.za/presentations/avusa.pdf

Baker, P. (1990). "A Turbulent Transition." Journal of Democracy, l (4), 8-24.

Bauer, T. (2009). "A democratised market? Development of South Africa's daily newspapers 1990 - 2006." Global Media Journal African Edition 3 (1), 1-17. Retrieved from http://sun025.sun.ac.za/portal/page/portal/Arts/Departemente 1/Joernalistiek/Glob al\%20Media\%20Journal/Global\%20Media\%20Journal\%20-\%20Home 
Berger, G. (2002). "Deepening Media Diversity: What South African Freedom Shows Us." The Round Table , 91 (366), 533-543.

Berger, G. (2001). "De-racialization, Democracy and Development: Transformation of the South African Media 1994-2000.” In K. Tomaselli, \& H. Dunn (Eds.), Media, Democracy and Renewal in Southern Africa (pp. 151-180). Colorado Springs, CO: International Academic Publishers Ltd.

Biko, B.S. (ed). (1972). Black Viewpoint. Durban: Spro-cas Black Community Programmes. Retrieved from the South African History Online website: http://www.sahistory.org.za/pages/library-resources/online\%20books/blackviewpoint/black-viewpoint.htm

Biko, B.S. (1972). “Introduction.” In B.S. Biko (Ed.), Black Viewpoint (n.p.). Durban: Spro-cas Black Community Programmes. Retrieved from the South African History Online website: http://www.sahistory.org.za/pages/libraryresources/online\%20books/black-viewpoint/black-viewpoint.htm

Blythe Schutte, L. (1997). "The Kagiso Trust (South Africa)." The Synergos Institute Voluntary Sector Financing Program Case Studies of Foundation-Building in Africa, Asia and Latin America. Retrieved from http://www.synergos.org/knowledge/97/ktcasestudy.pdf

Blackwell, L., \& Bamford, B. R. (1963). Newspaper Law of South Africa. Cape Town: Juta \& Company Limited.

Bond, P. (2004). Elite Transition: From Apartheid to Neoliberalism in South Africa. $2^{\text {nd }}$ Edition. Pietermaritzburg: University of Kwa-Zulu Natal Press.

Broughton, M. (1961). Press and Politics of South Africa. Cape Town: Purnell \& Sons Limited.

Brown, K. (2008, August 5). "South Africa: Zuma's allies flay judiciary, prosecutors.” Retrieved from the Business Day website: http://www.businessday.co.za/Articles/Content.aspx?id=51612

Brown, R. D. (1996). The Strength of a People: The Idea of an Informed Citizenry in America, 1650-1870. Chapel Hill: University of North Carolina Press. 
Brümmer, S, Sole, S and Basson, A. (2008, August 8). "The spy who fingered Mbeki." Retrieved from the Mail \&Guardian Online website:

http://www.mg.co.za/article/2008-08-08-the-spy-who-fingered-mbeki

Callinicos, L. (1982). Gold and Workers 1886-1924. Johannesburg: Ravan Press.

Campbell, G. (2004). Blood Diamonds: tracing the deadly path of the world's most precious stone. Boulder, CO: Westview Press.

The Caxton and CTP Group. (n.d.). A brief history of Caxton's from humble beginnings to a multi-billion company! Retrieved 14 November 2007 from http://www.caxton.co.za/pages/Caxton_History.php

Chapman, S.D. (1987). "Investment groups in India and South Africa." Economic History Review 2 (2), 275-280.

Chinapen, R. and Vernon, R. (2006). "Justice in Transition." Canadian Journal of Political Science 39, 117-134.

City Press. (2007, September 9). "Biko in his own words." Retrieved from the South African History Online website:

http://www.sahistory.org.za/pages/people/special\%20projects/biko_steve/archive. htm

Collection Level Description: Papers of the Central Mining and Investment Corporation Limited. (n.d.). Retrieved from the Bodleian Library, University of Oxford website 10 March 2008:

http://www.bodley.ox.ac.uk/dept/scwmss/wmss/online/blcas/central-mining.html

Commission for Employment Equity. (2009). Annual Report 2008 - 2009. Retrieved from http://www.pmg.org.za/files/docs/090825employmentequityreport.pdf

Comtask. (1996, October). Brief for the Task Group on Government Communications. Retrieved from the Government Communication and Information System website: http://www.gcis.gov.za/docs/govcomm/comtask/mandate.htm

Comtask. (1996, October). Communications 2000: A vision for government communications in South Africa. Retrieved from the Government Communication 
and Information System website:

http://www.gcis.gov.za/docs/govcomm/comtask/index.html

Cooper, D. (2001). 'Collective Responsibility, 'Moral Luck,' and Reconciliation." In A. Jokic (Ed.), War Crimes and Collective Wrongdoing (pp. 205-215). Oxford: Blackwell.

Curran, J. (1991). "Mass media and democracy: a reappraisal." In J. Curran, \& M. Gurevitch (Eds.), Mass Media and Society (pp. 82-117). London: E. Arnold.

Dahl, R. A. (1989). Democracy and its Critics. New Haven: Yale University Press.

Dahlgren, P. (1995). Television and the Public Sphere : Citizenship, Democracy, and the Media. Thousand Oaks, California: Sage Publications.

Dahlgren, P., \& Sparks, C. (Eds.). (1991). Communication and Citizenship : Journalism and the Public Sphere in the New Media Age. New York: Routledge.

Davis, G. (2004). Media Coverage and the Elections: Were Some Parties More Equal than Others? Retrieved from the University of Cape Town Centre for Social Science Research: http://www.commerce.uct.ac.za/Research_Units/CSSR/Working\%20Papers/paper s/wp69.pdf

Dewey, J. (1939). Freedom and Culture. New York: Capricorn Books.

Dewey, J. (1946). The Public and its Problems. Chicago: Gateway.

Durham Peters, J. (1993). "Distrust of representation: Habermas on the public sphere." Media, Culture and Society, 15, 541-571.

Financial Mail. (2000, June 30). "The consortium has kept the vision in mind." Retrieved from http://secure.financialmail.co.za/report/johnnic/bjnc.htm

Financial Mail (2009). Company History. Retrieved from http://www.empowerment.co.za/beAboutUs.aspx

Flew, T. (2007). Understanding Global Media. Houndmills, Basingstoke: Palgrave Macmillan. 
Fourie, P.J. (ed.). (2004). Media Studies: Institutions, Theories and Issues. Lansdowne: Juta Education.

Fraser, M (1987). "International Archives in South Africa". Business and Economic History, Second Series, 16, Library of Congress Catalog No. 87-72645. Retrieved from

http://www.h-net.org/ business/bhcweb/publications/BEHprint/v016/p0163p0174.pdf

Fredrickson, G. (1995). Black Liberation: A Comparative History of Black Ideologies in the United States and South Africa. New York: Oxford University Press.

Friedman, S. (2006). Participatory governance and citizen action in post-apartheid South Africa. Retrieved from the International Labour Organization website: http://www.oit.org/public/english/bureau/inst/publications/discussion/dp16406.pd f

Fussell, P (2000). The Great War and Modern Memory. New York: Oxford University Press.

Freedom of Expression Institute. (1997, June 6). FXI Makes Submission to the Truth and Reconciliation Commission on Role of Media During Apartheid. Retrieved from http://www.fxi.org.za/archive/Linked/press/1997/trcmed.htm

Freedom of Expression Institute. (1997, September 12 - 18). Media and human rights. Retrieved from http://www.fxi.org.za/old\%20webpages/archives/Weekrep/wk030997.htm

Freedom of Expression Institute. (2008, June 20). FXI submission on Protection of Information Bill. Retrieved from http://www.fxi.org.za/content/view/198/1/

Golding, P. (1997). The Political Economy of the Media (Vol. 1). Brookfield: Edward Elgar Publishing Limited.

Gordon Institute of Business Science. (2008, July 10). The SA press: "mirror of society" or "merchant of chaos"? Retrieved from http://www.gibs.co.za/home.asp?pid=125\&toolid=2\&itemid=28936

Gumede, W. (2006, June 28). Democracy, Transformation and the Media: the role of the media in strengthening democracy. Retrieved from the Caribbean Development 
Bank website:

http://www.caribank.org/titanweb/cdb/webcms.nsf/AllDocSearch/3E47127C3EE F2C270425740400612231/\$File/GumedeCaribbeanBankSpeech.pdf?OpenEleme nt

Habermas, J. (1974). “The Public Sphere: An Encyclopedia Article." New German Critique , 1 (4), 49-55.

Habermas, J. (1989). The Structural Transformation of the Public Sphere: An Inquiry into a Category of Bourgeois Society. Cambridge, MA: MIT Press.

Hadland, A (ed.). (2005). Changing the Fourth Estate: Essays on South African Journalism. Cape Town: HSRC Press.

Harber, A. (2008, June 13). Of aliens and mobs. Message posted to http://www.theharbinger.co.za/wordpress/2008/06/13/of-aliens-and-mobs/

Haupt, P. (1996). The SAARF Universal Living Standards Measure (SU-LSM ${ }^{\mathrm{TM}}$ ): 12 years of continuous development. Retrieved January 7, 2009 from the South African Advertising Research Foundation website: http://www.saarf.co.za/LSM/lsm-article.htm

Herman, E., \& Chomsky, N. (1988). Manufacturing Consent: the Political Economy of the Mass Media. New York: Pantheon Books.

Horwitz, R. B. (2001). Communication and Democratic Reform in South Africa. Cambridge: Cambridge University Press.

Huntington, S. P. (1991). The Third Wave: Democratization in the Late Twentieth Century. Norman: University of Oklahoma Press.

Hyden, G., Leslie, M., and Ogundimu, F.F. (eds.). (2002). Media and Democracy in Africa. New Brunswick, N.J.: Transaction Publishers.

Independent Newspapers. (1997). "Independent Newspapers' Submission to the TRC." Retrieved from the Department of Justice and Constitutional Development website: http://www.doj.gov.za/trc/submit/inc.htm

Independent News and Media PLC. (1997). Annual Report 1997. Retrieved from http://www.inmplc.com/main.php?menu=menu4\&mb=anr 
Independent News and Media PLC. (2008). Annual Report 2008. Retrieved from http://www.inmplc.com/reports/uploads/INM_Annual_Report_2008.pdf

Innes, D. (1984). Anglo American and the Rise of Modern South Africa. London: Heinemann Educational Books.

International Marketing Council of South Africa. (2009). The Press in South Africa. Retrieved January 7, 2009, from the MediaClubSouthAfrica website: http://www.mediaclubsouthafrica.com/index.php?option=com_content\&view=arti cle \&id $=73 \% 3$ Apress \& catid $=36 \% 3$ Amedia_bg \&Itemid $=54 \& 5920306 \mathrm{c} 3 \mathrm{~cd} 3 \mathrm{~b} 3355$ $5 \mathrm{c} 41 \mathrm{dOfdb} 96 \mathrm{~d} 16 \mathrm{a}=98176 \mathrm{f} 7 \mathrm{bced} 3 \mathrm{~b} 6 \mathrm{e} 7 \mathrm{~b} 8 \mathrm{ed} 7403527986 \mathrm{bd} \&$ limitstart $=1 \& 592030$ $6 c 3 c d 3 b 33555 c 41 d 0 f$ db96d16a $=98176 f 7 b c e d 3 b 6 e 7 b 8 e d 7$

Isa, M. (2008, November 12). "Economy guru urges SA's left to mind their statements." Retrieved from the Business Day website: http://www.businessday.co.za/Articles/Content.aspx?id=56534

Jacobs, S. (1999). "The Media and the Elections." In A. Reynolds (Ed.), Election '99 South Africa: From Mandela to Mbeki, (pp. 147-158). New York: St. Martin's Press.

Jacobs, S. (2003). "How Good is the South African Media for Democracy? Mapping the South African Public Sphere after Apartheid." In Zegeye, A. and Harris, R. (Eds.). Media, identity and the public sphere in post-apartheid South Africa, (pp. 41-64). Boston: Brill.

Jefferson, T. (1939). Democracy. (S. K. Padover, Ed.). New York: D. Appleton-Century Company Incorporated.

Kagiso Media. (2009). About Kagiso Media. Retrieved 14 May 2008 from http://www.kagisomedia.co.za/content/view/12/20

Keane, J. (1991). The Media and Democracy. Cambridge, MA: Polity Press.

Krog, A. (2000). Country of My Skull: Guilt, Sorrow and the Limits of Forgiveness in the New South Africa. New York: Three Rivers Press.

Kruger, F. Black, White and Grey: Ethics in South African Journalism. Cape Town: Double Storey Books. 
Limb, P. (2000). "Representing the Labouring Classes: African Workers in the African Nationalist Press, 1900 - 1960." In L. Switzer and M. Adhikari (Eds.), South Africa's Resistance Press: Alternative Voices in the Last Generation Under Apartheid (pp. 79-127). Ohio: Ohio University Press.

Locke, J. (1980). Second Treatise of Government. (C. Macpherson, Ed.) Indianapolis: Hackett Publishing Company. (Original work published 1690).

Louw, P. E. (1995). "Shifting Patterns in South Africa's Press Oligopoly." Media International Australia (77), 73-85.

Magubane, Z. (2004). Bringing the Empire Home: Race, Class and Gender in Britain and Colonial South Africa. Chicago: University of Chicago Press.

Marais, H. (1998). South Africa, Limits to Change: The Political Economy of Transition. London: Zed Books Ltd.

Masilela, N (1990, April 30). "Black South African literature from the 'Sophiatown Renaissance' to 'Black Mamba Rising': Transformations and Variations from the 1950s to the 1980s." Retrieved from http://pzacad.pitzer.edu/NAM/general/essays/nxumalo.htm

McChesney, R. (1999). Rich Media, Poor Democracy: Communication Politics in Dubious Times. Urbana: University of Illinois Press.

McCombs, M (2005). "A Look at Agenda-setting: past, present and future." Journalism Studies, 6 (4), 543-557.

McGregor, R (July 1994). “Aunty Argus marries an Irish cousin.” Rhodes Journalism Review 12, pp 1-2. Retrieved from the Rhodes University Rhodes Journalism Review website: http://www.rjr.ru.ac.za/rjrpdf/rjr_no8/aunty_argus.pdf

McGregor, R (1996a, October). Annexure 3 Patterns of Ownership and Control of the South Africa Media. Johannesburg: Comtask.

McGregor, R. (1996b, December). "How the guard has changed since Rhodes stormed the SA economy." Retrieved from the Sunday Times/Business Times website: http://www.btimes.co.za/96/1215/columns/news3.htm 
McPhail, T. L. (2006). Global Communication: Theories, Stakeholders, and Trends (2nd ed.). Malden, MA: Blackwell Publishing Ltd.

Media Monitoring Africa. (2008, October 27). MMP/Daily Sun settlement. Retrieved from

http://www.mediamonitoringafrica.org/index.php/news/entry/mmp_daily_sun_set tlement/

Media Monitoring Africa. (2009, March 18). Daily Sun brings attention to forced marriages affecting children. Retrieved from

http://www.mediamonitoringafrica.org/index.php/resources/entry/daily_sun_bring s_attention_to_forced_marriages_affecting_children/

Media Monitoring Africa. (2009, April 30). Daily Sun features child heroine. Retrieved from http://www.mediamonitoringafrica.org/index.php/resources/entry/daily_sun_featu res_child_heroine/

Media Monitoring Project. (1996, October). Annexure 2 Communicating Government: Government Coverage in the media 1 April 1996 - 23 June 1996. Johannesburg: Comtask.

Media Tenor. (2005). 'Aids fatigue' still media's excuse? Retrieved from http://www.mediatenor.com/pdf/as_case_studies/AgendaCutting_Aids.pdf

Media Update. (2007, November 13). ILANGA (Monitored). Retrieved from http://www.mediaupdate.co.za/default.aspx?IDStory $=4208$

Media Update. (2007, November 13). llanga continues to set the standard in KwaZuluNatal. Retrieved from http://www.mediaupdate.co.za/default.aspx?IDStory=4208

Media Update. (2007, November 13). Ilanga fights Independent giant. Retrieved from http://www.mediaupdate.co.za/default.aspx?DStory $=4208$

Media Update. (2007, November 13). Media24 to represent llanga papers, instead of $N A B$. Retrieved from http://www.mediaupdate.co.za/default.aspx?IDStory $=4208$

Memela, S. (2008, February 1). "The trial of John Tengo Jabavu for (mis)representing African opinion." Retrieved from the Mail and Guardian Online Thought Leader website: http://www.thoughtleader.co.za/sandilememela/2008/02/01/the-trial-ofjohn-tengo-jabavu-for-misrepresenting-african-opinion/ 
Meredith, M. (2007). Diamonds, Gold and War: the British, the Boers and the Making of South Africa. New York: Public Affairs.

Michie, J., \& Padayachee, V. (1997). “South Africa's Transition: The Policy Agenda.” In J. Michie, \& V. Padayachee (Eds.), The Political Economy of South Africa's Transition: Policy Perspectives in the Late 1990s (pp. 1-26). London: The Dryden Press.

Mill, J.S. (1859). On Liberty. London: Oxford University Press.

Milne, C, and Taylor, A. (2006). African Media Development Initiative: South Africa Context. Retrieved from http://downloads.bbc.co.uk/worldservice/trust/pdf/AMDI/south_africa/amdi_sa_f ull_report.pdf

Mosco, V. (1996). The Political Economy of Communication: Rethinking and Renewal. London: SAGE Publications Ltd.

Murdock, G. (1997). "For a Political Economy of Mass Communications." In P. Golding (Ed.), The Political Economy of the Media Volume 1 (pp. 3-32). Brookfield: Edward Elgar Publishing Limited.

Murdock, G. (1982). "Large corporations and the control of the communications industries.” In T. B. Michael Gurevitch (Ed.), Culture, Society and the Media (pp. 118-173). New York: Methuen.

Naidu, Edwin. (2008, March 16). Black middle class growing and spending. Retrieved from Independent Online website: http://www.iol.co.za/index.php?set_id=1\&click_id=124\&art_id=vn20080316091 259988C213468

Naspers. (2009). Company History 1915 - 2006. Retrieved from http://www.naspers.com/index.cfm?content $=2924$

National Press Club. (2009). Who owns SA's newspapers. Retrieved from http://www.nationalpressclub.co.za/media_owns.html 
Naughton, T. (2008, January 3). South African broadcasting and the MDA. Retrieved from the Freedom of Expression Institute website:

http://www.fxi.org.za/content/view/163/56/

Ndebele, N. (1972). "Black Development." In B.S. Biko (Ed.), Black Viewpoint (n.p.). Durban: Spro-cas Black Community Programmes. Retrieved from the South African History Online website: http://www.sahistory.org.za/pages/libraryresources/online\%20books/black-viewpoint/black-viewpoint.htm

Ndletyana, M. (2008). "Introduction." In M. Ndletyana (Ed.), African intellectuals in the 19th and early 20th century South Africa (pp. 1-6). Cape Town: HSRC Press.

Ndletyana, M. (2008). "John Tengo Jabavu." In M. Ndletyana (Ed.), African intellectuals in the 19th and early 20th century South Africa (pp. 31-44). Cape Town: HSRC Press.

Nix, J. (1995). “Actions against journalists in South Africa between 1960 and 1994.” The Laura Pollecut Collection. Retrieved from the University of the Witswatersrand Traces of Truth: Documents database: http://truth.wwl.wits.ac.za/doc_page.php?did=1193\&li=cat

Olorunnisola, A. (2006). Media in South Africa after Apartheid: A Cross-Media Assessment. Lewiston: Edwin Mellen Press.

O'Meara, D. (1983). Volkskapitalisme - Class, Capital and Ideology in the Development of Afrikaner Nationalism 1934-1948. Cambridge: Cambridge University Press.

O'Neill, P. H. (1998). "Democratization and Mass Communication: What is the Link?" In P. H. O'Neil (Ed.), Communicating Democracy: The Media and Political Transitions, (pp. 1- 20). Boulder: Lynne Rienner Publishers.

Pallister, D., Stewart, S., \& Ian, L. (1987). South Africa Inc. The Oppenheimer Empire. London: Simon \& Schuster.

Park, M., and Curran, J. (eds.). (2000). De-westernizing Media Studies. New York: Routledge.

Powell, C. (2005). "Terrorism and governance in South and Eastern Africa." In M. Yew Meng Hor, V. Vridar Ramraj, and K. Roach (Eds.), Global Anti-Terrorism Law and Policy (pp. 555-580). New York: Cambridge University Press. 
Power, M and Maker, J. (3 August 2008, August 3). "Mbeki took R30m, gave some to Zuma." The Sunday Times, pp. A1, A4.

Republic of South Africa. (1993a). Constitution of the Republic of South Africa 1993. Retrieved from http://www.info.gov.za/documents/constitution/93cons.htm

Republic of South Africa. (1993b). Regulation of Gatherings Act. Retrieved from http://www.info.gov.za/acts/1993/a205-93.pdf

Republic of South Africa. (1993c). The Key Issues in the Normative Economic Model. Pretoria: Government Printer.

Republic of South Africa. (1996). Constitution of the Republic of South Africa 1996. Retrieved from http://www.info.gov.za/documents/constitution/index.htm

Republic of South Africa. (1998a). Truth and Reconciliation Commission Report Volume 4 Institutional Hearings. Retrieved from the Department of Justice and Constitutional Development website: http://www.justice.gov.za/trc/report/finalreport/Volume\%204.pdf

Republic of South Africa. (1998b). Truth and Reconciliation Commission Report Volume 5 Recommendations. Retrieved from the Department of Justice and Constitutional Development website: http://www.doj.gov.za/trc/report/finalreport/TRC\%20VOLUME\%205.pdf

Republic of South Africa. (1998c). Truth and Reconciliation Commission Report Volume 2 Chapter 7 Political Violence in the Era of Negotiations and Transition. Retrieved from the Department of Justice and Constitutional Development website: http://www.justice.gov.za/trc/report/finalreport/Volume\%202.pdf

Republic of South Africa. (2002). About GCIS. Retrieved December 4, 2007 from the Government Communication and Information System website: http://www.gcis.gov.za/about/index.html

Republic of South Africa. (2003a). Protection of Constitutional Democracy Against Terrorist and Related Activities Bill. Retrieved from http://www.info.gov.za/view/DownloadFileAction?id=66478

Republic of South Africa. (2003b). Truth and Reconciliation Report Volume 6 Reparations. Retrieved from http://www.info.gov.za/otherdocs/2003/trc/rep.pdf 
Republic of South Africa. (2006a). Films and Publications Amendment Bill. Retrieved from http://www.info.gov.za/view/DownloadFileAction?id=100821

Republic of South Africa. (2006b). South Africa's Economic Transformation: A Strategy for Broad-Based Black Economic Empowerment. Retrieved December 4, 2007 from the Department of Trade and Industry website: http://www.dti.gov.za/bee/bee.htm

Republic of South Africa. (2008). Protection of Information Bill. Retrieved from http://www.info.gov.za/view/DownloadFileAction?id=82210

Republic of South Africa. (2009). Imbizo. Retrieved from the South African Government Information website: http://www.info.gov.za/issues/imbizo/index.html\#background

Rossouw, R. (2005). "The media and transformation." In A. Hadland (Ed.), Changing the Fourth Estate: Essays on South African Journalism (pp. 221-227). Cape Town: HSRC Press.

Rousseau, J. (1987). The Basic Political Writings. (D. Cress, Trans.) Indianapolis: Hackett Publishing Company.

Schiller, H. (1997). "Manipulation and the Packaged Consciousness." In P. Golding (Ed.), The Political Economy of the Media Volume 1 (pp. 412-437). Brookfield: Edward Elgar Publishing Limited.

Schutte, B. (1997). The Kagiso Trust (South Africa): A Case Study. Retrieved from http://www.synergos.org/knowledge/97/ktcasestudy.pdf

Smith, J. (2008, December 19). Zuma exacts defamation action on media. Retrieved from Independent Online website: http://www.iol.co.za/index.php?set_id=1\&click_id=3015\&art_id=vn2008121906 5220411C219357\$

South African Advertising Foundation. (2008). All Media Products Survey $2008 a$. Retrieved from the Print Media South Africa website: http://www.printmedia.org/za/static/downloads/industry_analysis.pdf 
South African Congress. (1955). Freedom Charter. Retrieved from the African National Congress website: http://www.anc.org.za/ancdocs/history/charter.html

South African History Online. (2000). A History of Drum Magazine. Retrieved from http://www.sahistory.org.za/pages/artsmediaculture/arts/media/drum.htm

South African History Online. (2000). Defiance Campaign. Retrieved from http://www.sahistory.org.za/pages/chronology/specialchrono/governance/defiance-campaign.htm

South African Human Rights Commission. (2000). Faultines: Inquiry into Racism into the Media. Retrieved from Polity.org: http://www.polity.org.za/polity/govdocs/reports/hrc/racism-media-00.pdf

South African National Editors' Forum. (2006). Executive Summary of Glass Ceiling 2. Retrieved from http://www.sanef.org.za/diversity/

South African Press Association. (1997a January 21). TRC says it will review its decision on media role probe. Retrieved from the Departmentof Justice and Constitutional Development website: http://www.doj.gov.za/trc/media/1997/9701/s970121i.htm

South African Press Association. (1997b, June 30). TML Denies it did not do enough to fight apartheid. Retrieved from the Department of Justice and Constitutional Development website: http://www.doj.gov.za/trc/media/1997/9706/s970630b.htm

South African Press Association. (1997c, September 17). TML needs to transform itself: Ramaphosa. Retrieved from the Departmentof Justice and Constitutional Development website: http://www.doj.gov.za/trc/media/1997/9709/s970917f.htm

South African Press Association. (2007, October 24). Conjecture - bread and butter of $S A$ media. Retrieved from the Independent Online website: http://www.iol.co.za/index.php?set_id=1\&click_id=13\&art_id=nw200710241434 44749C989091

South African Press Association. (2008, June 18). SAHRC slams 'killing for Zuma'. Retrieved from the News 24 website: http://www.news24.com/News24/South_Africa/Politics/0,2-7 


\section{2_2342814,00.html}

South African Press Association. (2008, July 3). Malema will never use 'kill' again. Retrieved from the News 24 website: http://www.news24.com/News24/South_Africa/Politics/0,2-712_2351404,00.html

South African Press Association. (2008, December 12). Court rejects ANC challenge against Cope name. Retrieved from the Mail \& Guardian Online website: http://www.mg.co.za/article/2008-12-12-court-rejects-anc-challenge-againstcope-name

South African Press Association. (2009, April 28). Tokolosh rape interview gets thumbsup. Retrieved from the Independent Online website: http://www.iol.co.za/index.php?from=rss_News\&set_id=1\&click_id=79\&art_id= nw20090428155540869C450733

Steenveld, L. (1998, July). "The transformation of the media: from what, to what?" Rhodes Journalism Review, pp 4-7.

Steinulfsson Skjerdal, T. (1997). Mapping the gap: South African journalists in disagreement over the Truth and Reconciliation Commission media hearings. Retrieved from http://www.geocities.com/CapitolHill/2152/trc.htm\#references

Sunday Times/Business Times (1996, October 20). Johnnic deal loses its magic.

Retreived from http://www.btimes.co.za/96/1020/news/news.htm

Switzer, L and Adhikari, M (Eds.). (2000). South Africa's Resistance Press: Alternative Voices in the Last Generation Under Apartheid. Ohio: Ohio University Press.

Switzer, L. (2000). "Introduction: South Africa's Resistance Press under Apartheid." In L. Switzer and M. Adhikari (Eds.), South Africa's Resistance Press: Alternative Voices in the Last Generation Under Apartheid (pp. 1-78). Ohio: Ohio University Press.

Tamarkin, M. (1996). Cecil Rhodes and the Cape Afrikaners. Portland: Frank Cass.

Thompson, A. (Ed.). (2007). The Media and the Rwanda Genocide. Ann Arbor MI: Pluto Press.

Thompson, A. (2007). The Responsibility to Report: a New Journalistic Paradigm. In A. 
Thompson (Ed.), The Media and the Rwanda Genocide (pp 433-445). Ann Arbor MI: Pluto Press.

Time Magazine. (1950, 7 September). Drum Beat in Africa. Retrieved from http://www.time.com/time/magazine/article/0,9171,825925,00.html

TNS Research Surveys. (2008). Black Diamonds. Retrieved from http://www.tnsresearchsurveys.co.za/our-expertise/black-diamond.html

Tomaselli, K., Tomaselli, R., \& Muller, J. (1987). The Press in South Africa. New York: St. Martin's Press Inc.

Tomaselli, K.G. (2000). "South African media, 1994-7: globalizing via political economy." In M. Park and J. Curran (Eds.), De-westernizing Media Studies (pp. 279-292). New York: Routledge.

Tomaselli, K.G. (2002). "Media Ownership and Democratization.” In G. Hyden, M. Leslie, and F.F. Ogundimu (Eds.), Media and Democracy in Africa (pp. 129-155). New Brunswick, N.J.: Transaction Publishers.

Townsend, K. (2006, October 18). Tabloid grabs South Africa market. Retrieved from BBC website: http://news.bbc.co.uk/2/hi/programmes/this_world/6045650.stm

Ukpanah, I. The Long Road to Freedom: Inkundla ya Bantu (Bantu Forum) and the African Nationalist Movement in South Africa, 1938-1951. Trenton, NJ: Africa World Press.

Valji, N. (2003, July 2). South Africa: no justice without reparation. Retrieved from the Open Democracy website: http://www.opendemocracy.net/faithafrica_democracy/article_1326.jsp.

Van der Westhuizen, C. (2007). White Power and the Rise and Fall of the National Party. Cape Town: Zebra Press.

Van Riet, W and Roberts, S. (2008). Seeing dead people: Exploring visuals of dead bodies in the media. Retrieved from the Media Monitoring Africa website: http://www.mediamonitoringafrica.org/images/uploads/20080910deadbodies.pdf

Voltmer, K. (2006). "The mass media and the dynamics of political communication in processes of democratization: An Introduction." In K. Voltmer (Ed.), Mass Media 
and Political Communication in New Democracies (pp. 1-20). London:

Routledge.

Waldmeir, P. (1997). Anatomy of a Miracle. London: Penguin Books.

Wasserman, H., \& De Beer, A. (2006). "Conflicts of interest? Debating the media's role in post-apartheid South Africa." In K. Voltmer (Ed.), Mass Media and New Democracies (pp. 59-75). London: Routledge.

Wilson, R. (2001). The Politics of Truth and Reconciliation in South Africa: Legitimizing the Post-Apartheid State. Cambridge: Cambridge University Press.

Winseck, D and Pike, M. (2007). Communication and Empire: Media, Markets, and Globalization, 1860-1930. Durham: Duke University Press.

\section{Personal Interviews}

Bird, W. (2008, July 16). Director. Media Monitoring Africa.

Brand, R. (2008, August 21). Pearson Chair of Economics Journalism. Rhodes University School of Journalism and Media Studies.

Duncan, J. (2008, July 28). Executive Director. Freedom of Expression Institute.

Harber, A. (2008, July 4). Caxton Professor of Journalism and Media Studies. University of Witwatersrand Journalism Programme.

Kamang, M. (2008, July 26). Journalist. Sunday World.

Kruger, F. (2008, August 4). Senior Lecturer. University of the Witswatersrand Journalism Programme.

Makhafola, J. (2008, July 22). Spokesperson for the Minister of Communication. Department of Communication.

Maseko, T. (2008, August 13). Chief Executive Officer. Government Communication and Information System.

Mehtar, F. (2008, August 7). Executive Director. South African National Editors' Forum. 
Monama, T. (2008, August 1). Journalist. Sowetan.

Nandipha, K. (2008, July 30). Former Journalist. City Press.

Ndlovu, N. (2008, July 23). Government Communicator. International, Peace and Security Communication Cluster, Government Communication and Information Service.

Ndlovu, V. (2008, August 2). Journalist. Sowetan.

Schreiner, W. (2008, July 17). Managing Director. Media Tenor.

Steenveld, L. (2008, August 21). Associate Professor. Rhodes University School of Journalism and Media Studies.

Thloloe, J. (2008, August 8). Press Ombudsman. Press Council.

Tsedu, M. (2008, August 5). Editor. City Press.

Van der Merwe (2008, July 31). Journalism Instructor. University of Johannesburg Department of Communication.

Van der Westhuizen, C. (2008, August 18). Trade Project Editor (Africa and Europe). Inter Press Service. 